\title{
Ground Water of
}

\section{the Lower Lake-}

Middletown Area

Lake County, California

By J. E. UPSON and FRED KUNKEL

GEOLOGICAL SURVEY WATER-SUPPLY PAPER 1297

Prepared in cooperation with the

California Division of

Water Resources

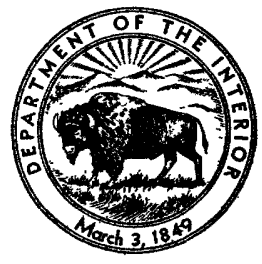


UNITED STATES DEPARTMENT OF THE INTERIOR

Douglas McKay, Secretary

GEOLOGICAL SURVEY

W. E. Wrather, Director

For sale by the Superintendent of Documents, U. S. Government Printing Office Washington 25 ,D. C. - Price 55 cents (paper cover 


\section{CONTENTS}

\begin{tabular}{|c|c|}
\hline \\
\hline 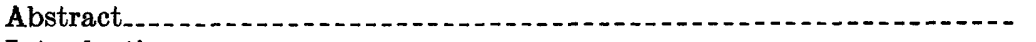 & \\
\hline 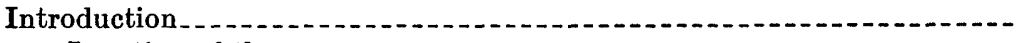 & \\
\hline Location of the area & \\
\hline Purpose and scope of the report & \\
\hline Well-numbering system & \\
\hline Historical note. & \\
\hline graphic and climatic features & \\
\hline 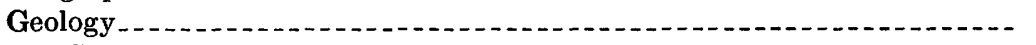 & \\
\hline Sedimentary rocks. & \\
\hline Consolidated rocks & \\
\hline Cache formation of Anderson & \\
\hline Older alluvium & 16 \\
\hline Recent alluvial deposits & 17 \\
\hline Igneous rocks & \\
\hline ine & \\
\hline rockss.-1- & \\
\hline 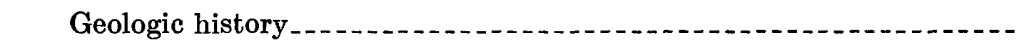 & \\
\hline round-water conditions by individual valleys & 1 \\
\hline Collayomi and Long Valleys & 21 \\
\hline Coyote Valley & 40 \\
\hline Excelsior and Little High Valleys...... & \\
\hline Manning Flat...... & \\
\hline Bonfield, Hesse, and Ely Flats. & \\
\hline Lower Lake area & \\
\hline Burns Valley & \\
\hline Borax Lake basin & \\
\hline Valley East of Clearlake Oaks........ & \\
\hline High Valley & \\
\hline - n-n & \\
\hline 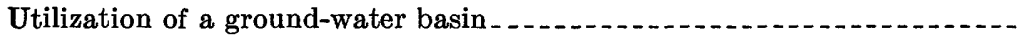 & \\
\hline thods of drilling and developing wells in the Lower Lake-Middletown & \\
\hline ted bibliography & \\
\hline 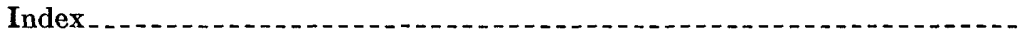 & \\
\hline
\end{tabular}

\section{ILLUSTRATION}

Plate 1. Ground-water basins of the Lower Lake-Middletown area, Lake County, Calif ......... In pocket. 


\section{TABLES}

Table 1. Monthly and yearly precipitation, in inches, at stations in and near Lake County, Calif

Page

2. Description of wells in the Lower Lake-Middletown area, Lake County, Calif.

3. Monthly and annual runoff, in acre-feet, of Putah Creek near Guenoc, Calif., in the water years 1904-06 and 1930-50

4. Chemical analyses of water from Cache Creek at Clear Lake, Calif

5. Monthly and annual runoff, in acre-feet, of North Fork of Cache Creek near Lower Lake, Calif., in the water years 1931-50.... 


\title{
GROUND WATER OF THE LOWER LAKE-MIDDLETOWN AREA, LAKE COUNTY, GALIFORNIA
}

\author{
By J. E. Upson and Fred KunKeL
}

\begin{abstract}
The Lower Lake-Middletown area in the southern part of Lake County, California, spans nine large valleys, each several miles long, and several small valleys.

The Middletown area lies at the headwaters of Putah Creek and comprises the drainage basins of Collayomi, Long, and Coyote Valleys. All of the ground water utilized in these valleys is derived from wells or sumps in the Recent alluvium. In Coyote Valley the alluvium may be underlain by water-bearing tuffs at depths greater than 100 feet, but in the other valleys it is underlain by non-water-bearing bedrock.
\end{abstract}

Ground-water development in Collayomi and Coyote Valleys can probably be increased. The physiography suggests that Putah and St. Helena Creeks meandered through these valleys, depositing tongues of coarse sand and gravel. These deposits should furnish several hundred gallons per minute to individual irrigation wells, an amount comparable to that yielded by sumps along the present course of St. Helena Creek. In Long Valley, however, it does not appear likely that a much increased ground-water development is possible. At present, perennial creeks do not flow through the valley, and the physiography suggests that most of the alluvium is fine grained.

All valleys of the Lower Lake area are tributary to Cache Creek, but each has a unique geologic and physiographic history.

The alluvium of Excelsior Valley, which lies south of the town of Lower Lake, is fine-grained, probably less than 50 feet thick, and underlain by non-waterbearing rocks. Increased ground-water development in this valley, even for domestic use, is not likely.

Manning, Bonfield, Hesse, and Ely Flats, which lie west of the town of Lower Lake, are underlain by a complex series of volcanic rocks. Information is not available to evalutate the potential ground-water supply.

The alluvial plain of Cache Creek, northeast of Lower Lake, and the alluvial plain of Herndon Creek, east of Lower Lake, are potential areas of increased ground-water development. However, the aluvium is thin, and part of the supply would probably come from the underlying Pliocene and Pleistocene Cache formation of Anderson. A more detailed study is desirable in this area.

Burns Valley, an elongate valley north of Clearlake Highlands, has had little ground-water development. In most places the alluvium is underlain by the Cache formation of Anderson, which in this area is composed mostly of clay and gravel. Carefully constructed wells may provide enough water for irrigation.

Borax Lake is in a closed basin northwest of Clearlake Park. The alluvium 
of this basin is underlain by non-water-bearing bedrock. With the exception of the water of a few domestic wells of low yield along the margin of the basin, the water yielded by the alluvium will probably be unsatisfactory for irrigation because of its high boron content.

A small unnamed valley lies east of Clearlake Oaks. The alluvium of this valley is probably fine grained, and, except for a few scattered bodies of fragmental rocks, is underlain by rocks of the non-water-bearing Franciscan group. Except for areas adjacent to Clear Lake, extensive ground-water development in this valley is not likely.

High Valley, which lies north of Clearlake Oaks, is isolated from main drainage lines. Its drainage pattern was altered by a volcanic flow that dammed the original outlet and allowed the valley to be filled with fine-grained alluvium. Except for the possibility of penetrating coarse gravel beneath the fine-grained alluvium, the ground water in High Valley probably cannot be further developed.

Long Valley, the northernmost valley considered, is alluvium-filled and underlain by non-water-bearing bedrock. Only one well has been drilled here, but the supply appears to be satisfactory for irrigation. Other wells could probably be drilled with similar success.

Increased development of the ground-water supplies of the Lower LakeMiddletown area is both possible and desirable. However, care must be exercised in the prospecting, locating, and drilling of wells, and consideration must be given to the occurrence, quality, and quantity of ground water available each year.

\section{INTRODUCTION}

\section{LOCATION OF THE AREA}

The Lower Lake-Middletown area lies in the southern part of Lake County, Calif., about 75 miles north of San Francisco Bay. It is a plateaulike, hilly, and mountainous part of the northern California Coast Ranges. Within the mountains are irregularly shaped, fairly shallow valleys, most of which occur along very irregular drainage lines. There are nine large valleys, each several miles long and with as much as 4,000 acres of arable land, and several small valleys. (See pl. 1.) Much of this land is irrigable, and in recent years some attempt has been made to develop surface and ground-water supplies for irrigation.

\section{PURPOSE AND SCOPE OF THE REPORT}

This report has been prepared at the request of the California Division of Water Resources in response to the need for information on the existing development of ground-water resources, and on the possibilities of increased development. It has been prepared as part of the cooperative investigation by the California Division of Water Resources and the U. S. Geological Survey of geologic features of the ground-water basins of Califorma. 
The investigation was made under the general direction of $\mathrm{A} . \mathrm{N}$. Sayre, chief of the Ground Water Branch of the U. S. Geological Survey, and under the supervision of J. F. Poland, district geologist for California.

Most of the field work was done during June, July, and August, 1950. Because only a short period of time was allotted, and because little ground-water data were available, the field work was strictly reconnaissance, and the report is of necessity preliminary. However, all existing information that may aid in estimating the potential ground-water development and in evaluating the need for further information is given. Estimates of the storage capacities of waterbearing deposits are included where available information furnishes a basis for them.

WELL-NOMBERING SYSTEM

The well-numbering system used by the U. S. Geological Survey in Lake County shows the locations of wells by reference to the rectangular system for the subdivision of public land. For example, in the number 11/6-19G3, which was assigned to a well in Coyote Valley, the part of the number preceding the bar indicates the township (T. $11 \mathrm{~N}$.); the number between the bar and the hyphen, the range (R. $6 \mathrm{~W}$.); the digits between the hyphen and the letter indicate the section (sec. 19); and the letter following the section number indicates the 40-acre subdivision of the section, as shown in the accompanying diagram. Within each 40 -acre tract the wells are numbered serially, as indicated by the final digit of the number.

\begin{tabular}{|c|c|c|c|}
\hline $\mathbf{D}$ & $\mathbf{C}$ & $\mathbf{B}$ & $\mathrm{A}$ \\
\hline $\mathrm{E}$ & $\mathrm{F}$ & $\mathrm{G}$ & $\mathrm{H}$ \\
\hline $\mathrm{M}$ & $\mathrm{L}$ & $\mathrm{K}$ & $\mathrm{J}$ \\
\hline $\mathbf{N}$ & $\mathbf{P}$ & $\mathbf{Q}$ & $\mathbf{R}$ \\
\hline
\end{tabular}


Thus, well $11 / 6-19 \mathrm{G} 3$ is the third well to be listed in the $\mathrm{SW} 1 / 4 \mathrm{NE}_{1 / 4}^{1 / 4}$ sec. 19. Because all of Lake County is north and west of the Mt. Diablo baseline and meridian, the foregoing abbreviation of the township and range is sufficient. Parts of some of the valleys have never been public land; for these the rectangular system of subdivision has been projected for reference purposes only. The abbreviated well numbers used on plate 1 consist of the letter indicating the 40 -acre subdivision of the section in which the well is located, and the serial number.

\section{FISTORICAL NOTE}

Old residents report that before 1900 several hundred Indians lived in each of the large valleys of the Lower Lake-Middletown area. Their staple food was the acorn, a bitter and mildly poisonous nut, which was gathered by the women and made palatable by grinding into a meal in stone mortars, leaching, and baking as cakes. To supplement this food, the men hunted deer from the hills and fished the waters of Clear Lake and the creeks.

Shortly after 1900, diseases reported as tuberculosis, smallpox, and measles rapidly wiped out most of the Indians. Their church, and the many framehouses in which they lived at that time, are now deserted, and only a few families have survived. Evidence has not been found to indicate that these Indians used wells in their culture. Apparently, their villages were always near a supply of surface water.

\section{GEOGRAPHIC AND CLIMATIC FEATURES}

The Lower Lake-Middletown area lies entirely within the northern California Coast Ranges. It is rough and mountainous, the relief ranging from 1,300 to 3,000 feet. Drainage of most of the valleys is integrated by the headwaters of Cache and Putah Creeks, which flow eastward to the Sacramento Valley. One of the largest valleys contains Clear Lake, about 65 square miles in area, and some of the small valleys also contain lakes or swamps.

Most of the mountains are covered by dense growths of manzanita and scrub oak, known as chaparral, and the valley bottoms are covered by native grasses and scattered oak trees. The valleys are alluvium-filled, and in places are dry-farmed for grains and alfalfa. Walnuts are also cultivated, the trees growing best on the deep, unirrigated soils of the hills. Because of the lack of water, irrigation is limited to the sprinkling of permanent pasture. However, the native grasses and the shallow dug wells, or water holes, along the creeks provide for many head of cattle. Deer, too, feed in the valleys, 
and are often a problem to the farmers because they trample down the grain.

The climate is Mediterranean, with moderate precipitation in the winter and little or none in the summer. (See table 1.) Temperatures for January average about $40^{\circ} \mathrm{F}$, and for July, about $70^{\circ} \mathrm{F}$; maximum and minimum temperatures range between $15^{\circ} \mathrm{F}$ and $110^{\circ}$ F. Records are not available for some of the smaller valleys, where the temperatures may be higher, or for the higher altitudes, where the temperatures may be lower. 


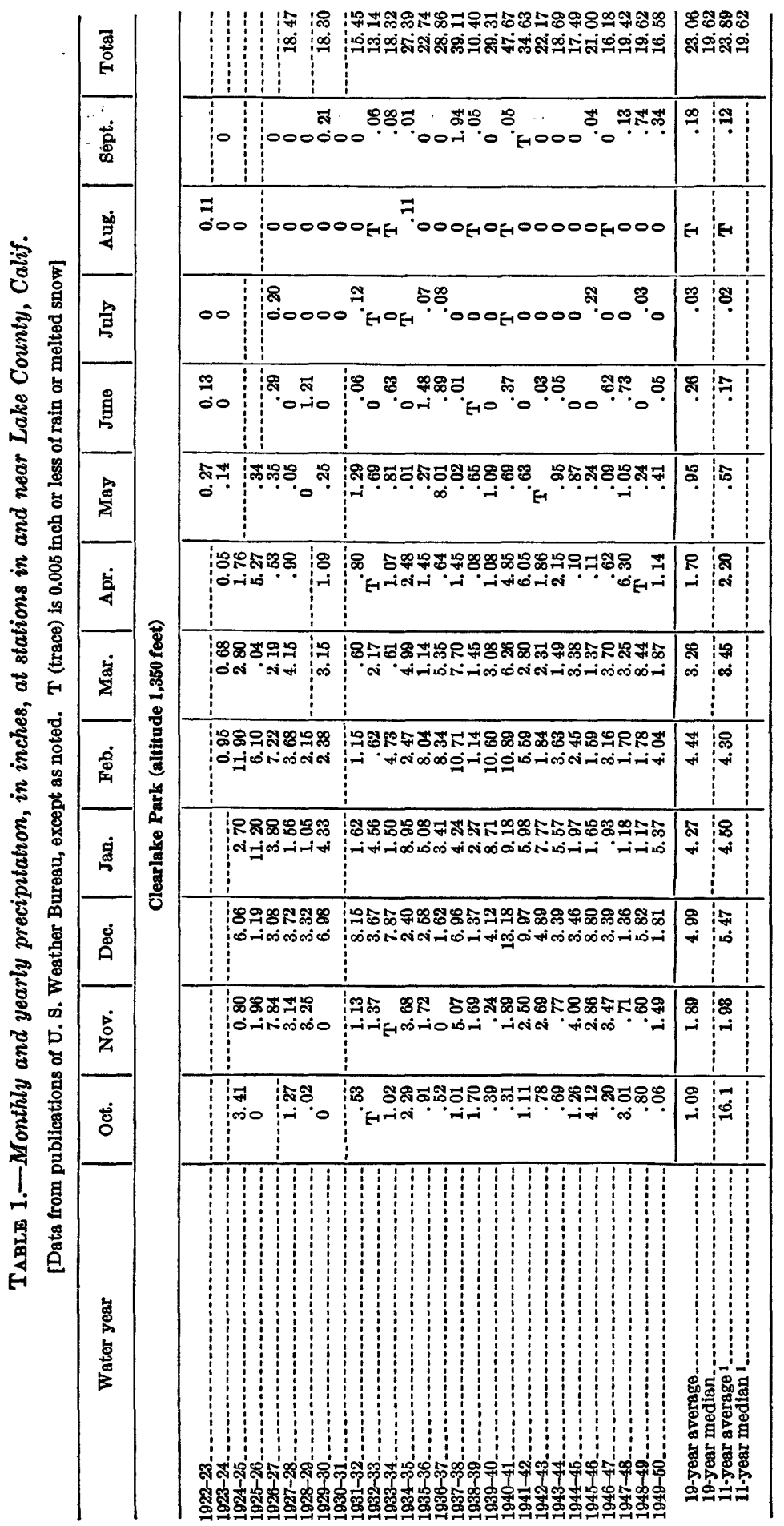




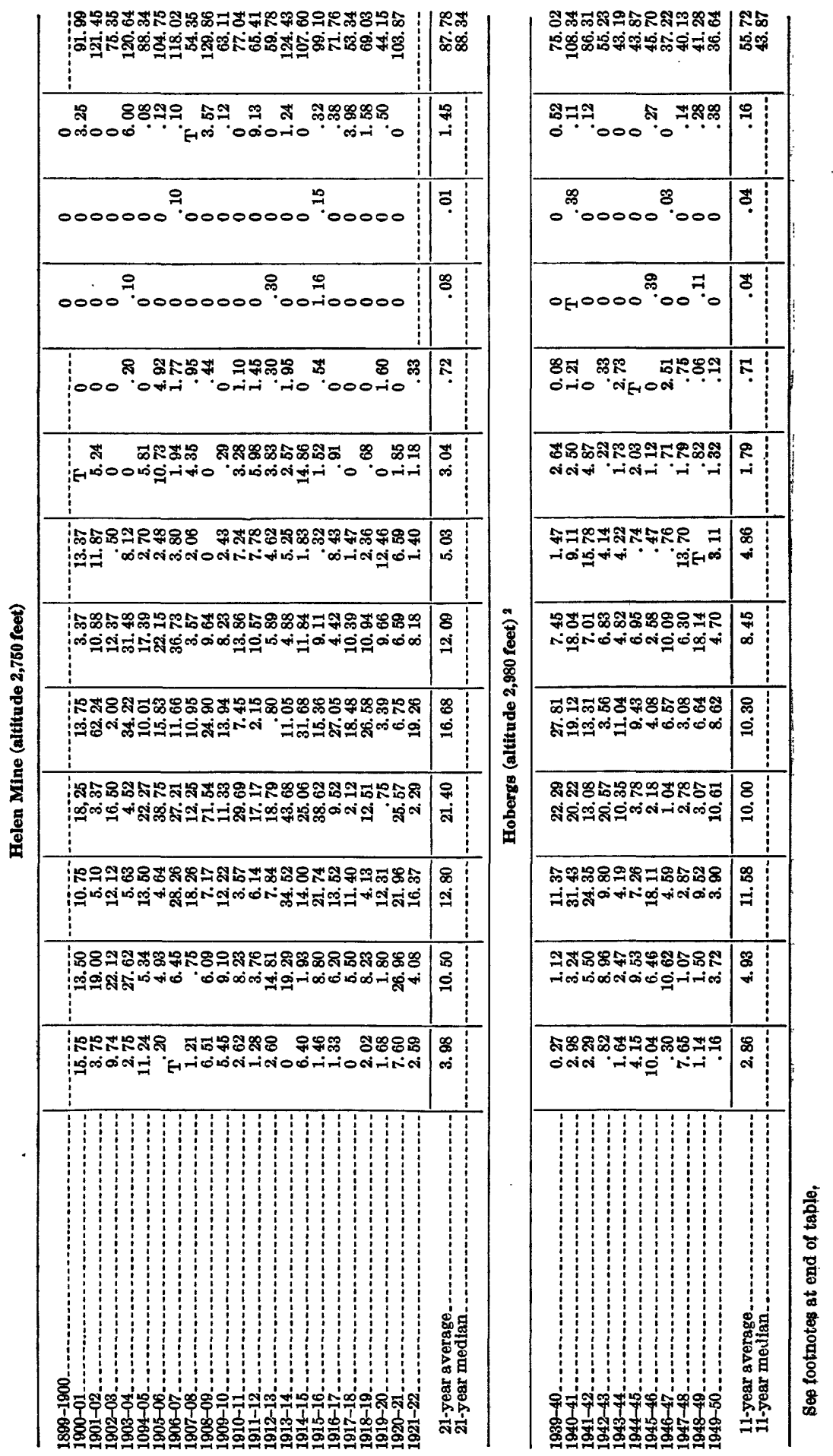


GROUND WATER, LOWER LAKE-MIDDLETOWN AREA, CALIF.

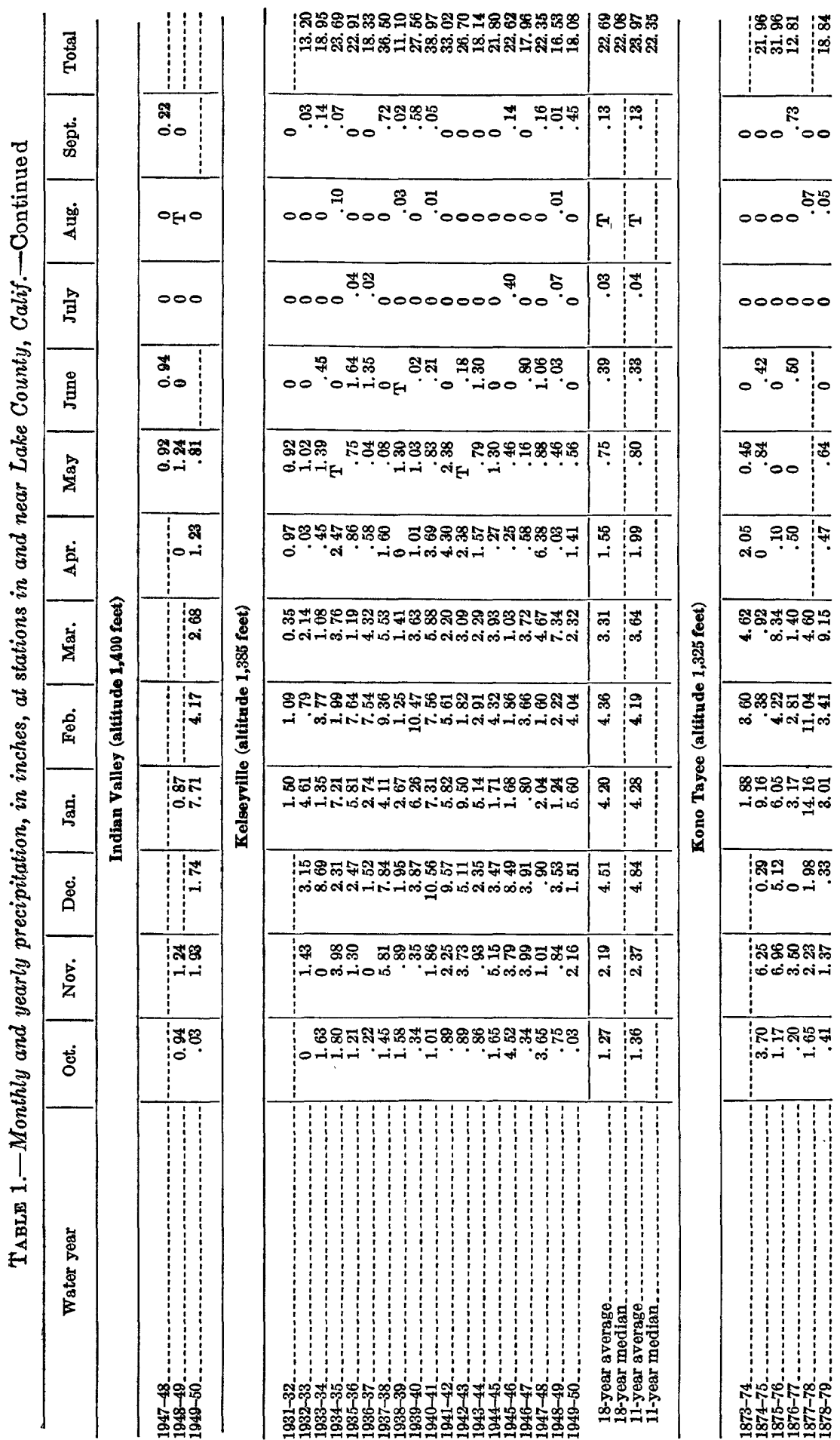


GEOGRAPHIC AND CLIMATIC FEATURES

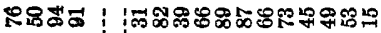

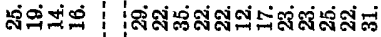

\begin{tabular}{|c|c|}
\hline 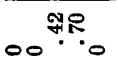 & 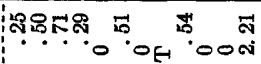 \\
\hline 00000 & OH \\
\hline 00000 & $000 \mathrm{H} 00^{\infty} \overbrace{\infty}^{\infty} 0000$ \\
\hline ํㅗ & 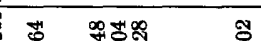 \\
\hline
\end{tabular}

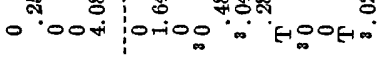

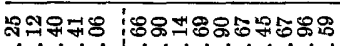

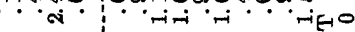

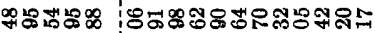

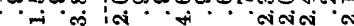

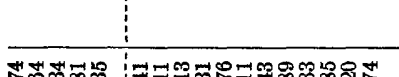

*

!

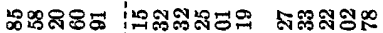

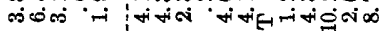

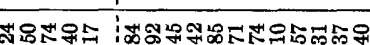

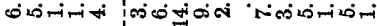

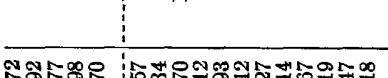

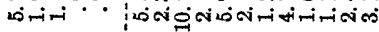

๙

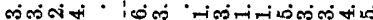

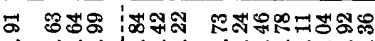

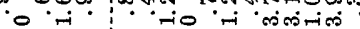

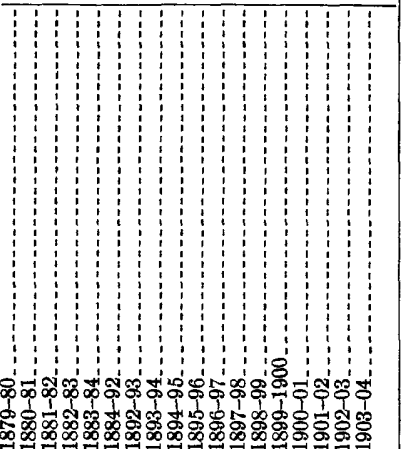

140 두요

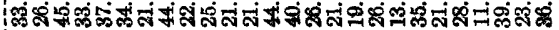

\$ 애

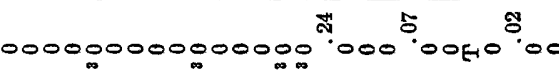

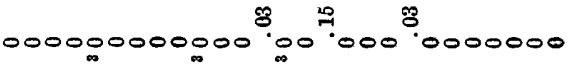
0000 ผ

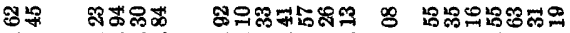

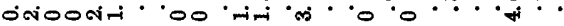

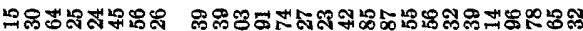

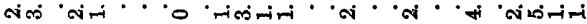

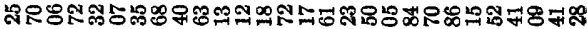

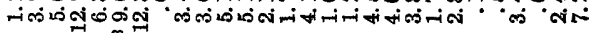

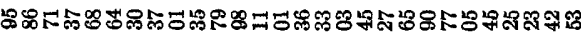

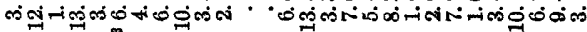

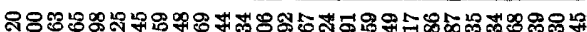

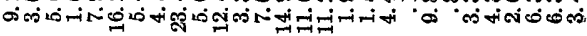

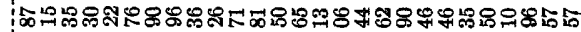

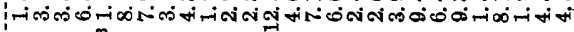

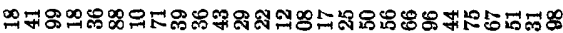

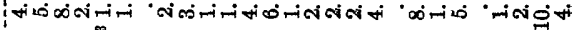

주용ำ

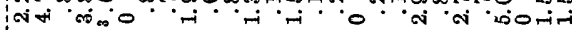

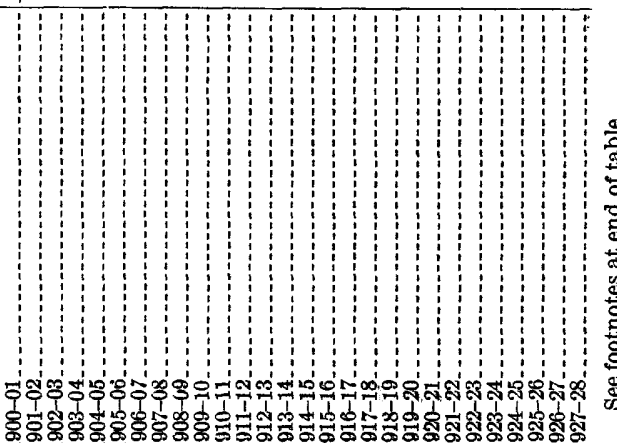


GROUND WATER, LOWER LAKE-MIDDLETOWN AREA, CALIF.
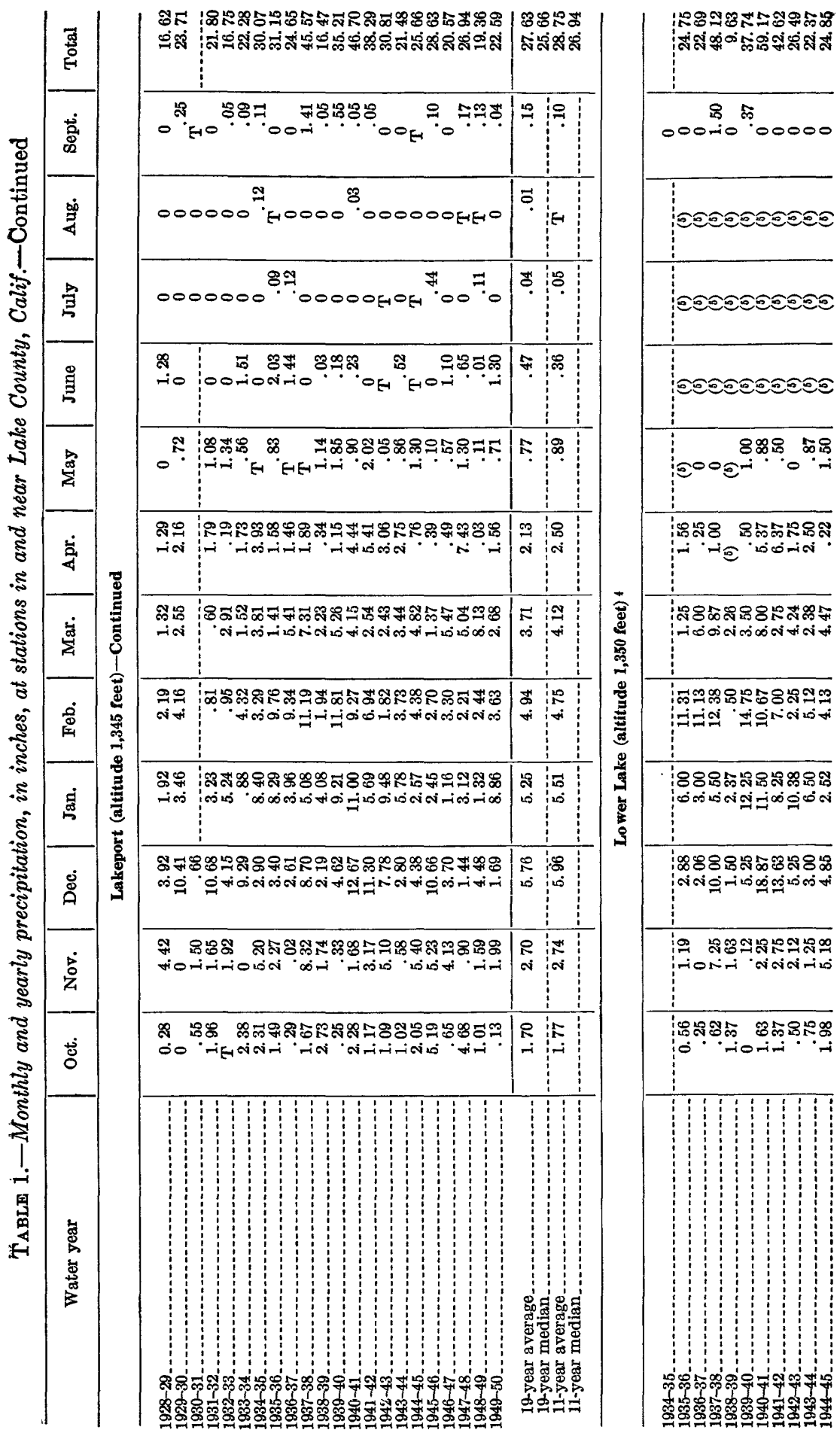


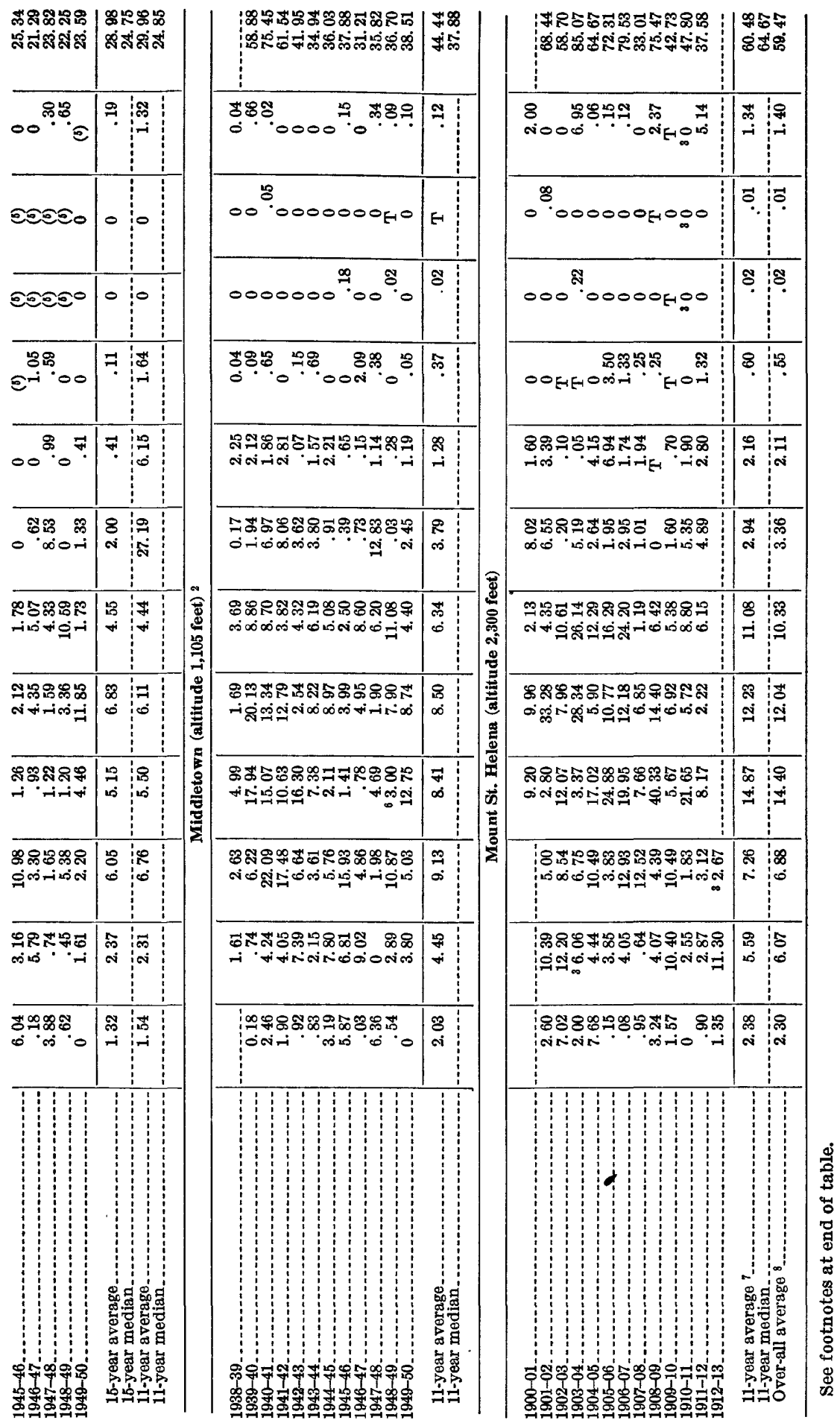




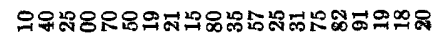

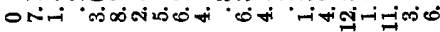

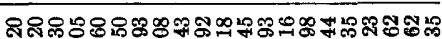

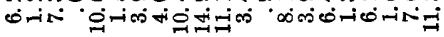

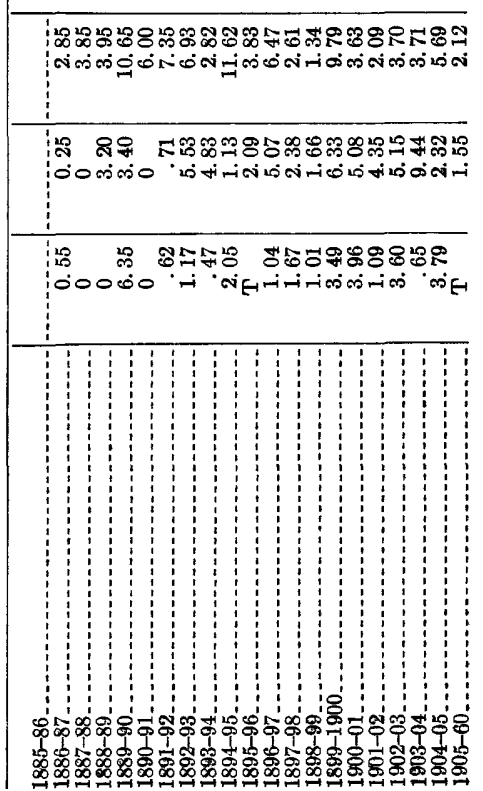




\begin{tabular}{|c|c|c|c|c|}
\hline 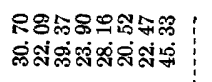 & 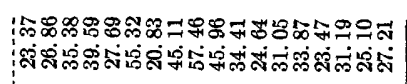 & & जिं & \\
\hline 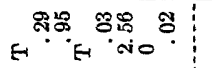 & สำ ৪สำ & & & \\
\hline 0 & 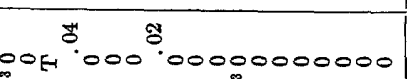 & o & & \\
\hline $0^{8} \cdot 00$ & 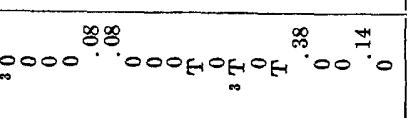 & 范 & $\stackrel{8}{\circ}$ & 褢 \\
\hline 8 & 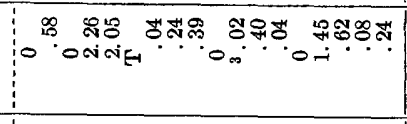 & & 尺్ & 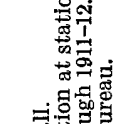 \\
\hline 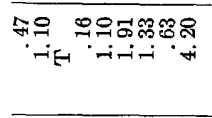 & 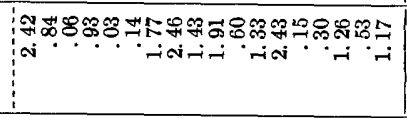 & $\stackrel{\circ}{-}$ & 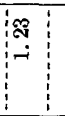 & 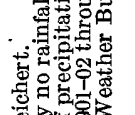 \\
\hline 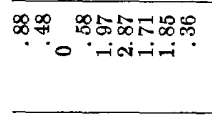 & 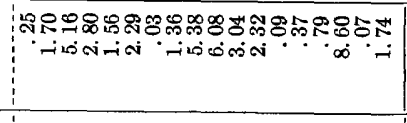 & 尔 & in & 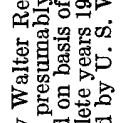 \\
\hline 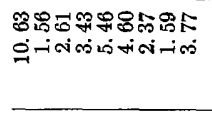 & 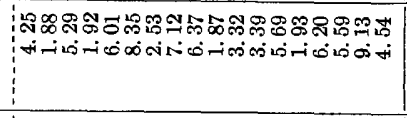 & $\stackrel{4}{i}$ & is & 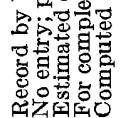 \\
\hline 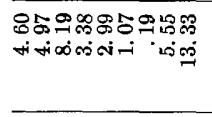 & 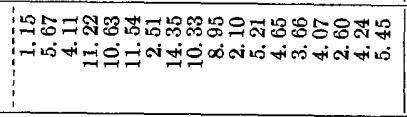 & ๙ึ & is & . \\
\hline 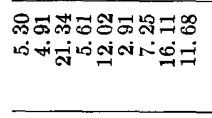 & 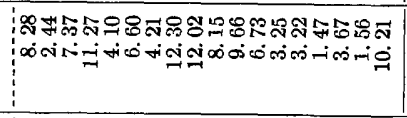 & $\stackrel{5}{5}$ & $0^{\circ}$ & 造: \\
\hline 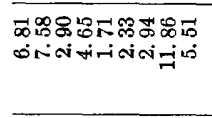 & 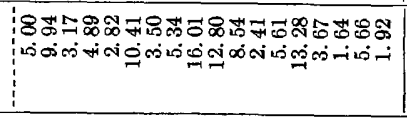 & \begin{tabular}{l}
$\infty$ \\
\multirow{2}{\infty}{} \\
0
\end{tabular} & $\begin{array}{l}8 \\
\infty\end{array}$ & 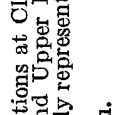 \\
\hline 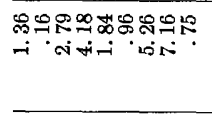 & 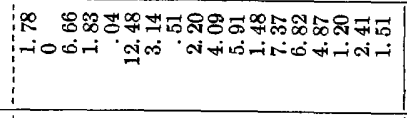 & 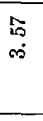 & क & 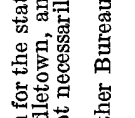 \\
\hline 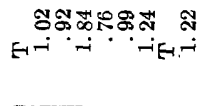 & 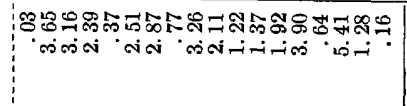 & $\begin{array}{l}\mathscr{8} \\
\text { id }\end{array}$ & $\begin{array}{c}8 \\
8 \\
4\end{array}$ & 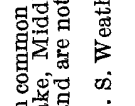 \\
\hline 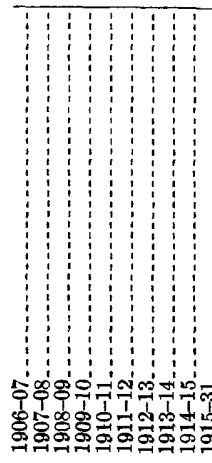 & 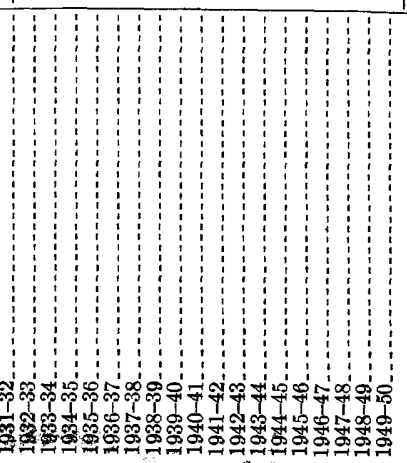 & & 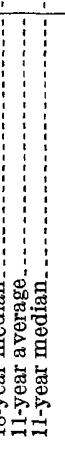 & 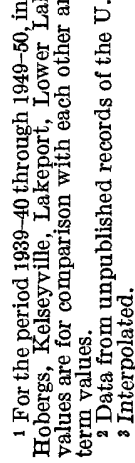 \\
\hline
\end{tabular}




\section{GEOLOGY}

The geology of the Lower Lake-Middletown area is relatively complex and differs considerably from one part of the area to another. Included are sedimentary, igneous, and metamorphic rocks that range in lithology from siliceous shales to unconsolidated alluvium, and from serpentinized basic intrusives to basaltic, andesitic, and rhyolitic extrusives. In age they range from Jurassic(?) to Recent. A complete examination of the geology of the entire area was not attempted. Previous studies were referred to, and some were drawn upon rather heavily, particularly that of Anderson (1936) on the region around the eastern end of Clear Lake.

The rock types and formational units that have been described, insofar as they could be recognized from reconnaissance observation, were briefly studied for each valley with respect to their water-bearing properties. In the following paragraphs they are described briefly, and a generalized statement of their geologic history is made.

\section{SEDIMENTARY ROCKS}

\section{CONSOLWATED ROCKS}

The consolidated sedimentary rocks consist of moderately compacted and silicified sandstones and shales and some serpentinized basic intrusives that belong to the Franciscan group (Jenkins, 1938), Knoxville formation, Chico formation, Shasta series, Martinez formation, and Tejon formation (Dickerson, 1914). These rocks range in age from Jurassic(?) to early Eocene, and all have been deformed by folding and faulting. Although their extent and relationships have not been studied in detail, it is known that the Franciscan rocks, generally the most metamorphosed, occur mainly in the southern and northern parts of the area, and that the Martinez and Tejon formations occur in the central part, southeast of Clear Lake.

An attempt was not made to separate the formations composed of these older consolidated rocks, and a separation is not shown on plate 1. Although they may locally contain minor quantities of water in fractures, they are essentially not water bearing, and are the floor upon which the younger water-bearing formations were deposited.

\section{CACHE FORMATION OF ANDERSON}

The Cache formation, first described by Becker (1888, p. 219) under the name "Cache Lake beds," is a thick series of fluvial and lacustrine clay, silt, sand, and gravel, with minor amounts of tuff, marl, and fresh-water nodular limestone. It is the oldest unconsolidated formation in the Lower Lake-Middletown area, and it crops out to the east and northeast of Clear Lake in a tract of several square miles. The extent of the formation, as shown on plate 1, is mainly 
after Anderson (1936) and Brice (1954). The name "Cache formation" was used by Anderson (1936, p. 633) because there is no Cache Lake in the vicinity and because the deposits are not all lacustrine. According to Anderson, the rocks of the Cache formation "consist chiefly of gravels and sands, striking in a general north-south direction, with westerly dips ranging from 10 to 20 degrees $* * *$ There are at least 1,700 feet of these gravels and sands exposed between Cache Creek and the Franciscan rocks to the west *** probably deposited in a subsiding basin." In the area bordering the southern arm of Clear Lake the dominant rocks of the Cache formation are fine sands and silts, in part tuffaceous. Locally, they contain intercalated gravel lenses and some marls and limestones.

Where observed in the vicinity of Lower Lake and Clearlake Highlands, the Cache formation of Anderson consists of fine sands, silts, and marls, with interbedded limestone, and is for the most part lacustrine. As indicated by logs of water wells, the formation consists of blue clay, sand, gravel, and limestone; these deposits suggest lacustrine conditions also, but the gravels may be fluvial.

The Cache formation is well exposed along State Highway 53 at Clearlake Highlands, and it extends eastward for an unknown distance beyond the North Fork of Cache Creek. At Clearlake Highlands a maturely dissected land surface, covered with a dense growth of chaparral, rises several hundred feet above the present lake level. The topography of most of the formation is indistinguishable from that of the older non-water-bearing formations. Usually, however, the western outcrops of the Cache formation are conspicuously white. Sand and gravel in thick beds crop out along State Highway 20 east of Clear Lake, suggesting that the source for some of the formation may have been in that direction.

Excellent exposures of the Cache formation occur near Lower Lake. West of State Highway 53 at Lower Lake High School, interbedded clay and gravel, with some limestone, strike N. $50^{\circ} \mathrm{W}$. and $\operatorname{dip} 40^{\circ} \mathrm{SW}$. In a cut bank north of the local church, beds of moderately indurated clay, clayey limestone, and limestone are exposed, the bedding striking $\mathrm{N} .70^{\circ} \mathrm{W}$. and dipping $59^{\circ} \mathrm{NE}$. About 1,500 feet north of well $12 / 7-3 \mathrm{~J} 1$, a bed of limestone has a strike of N. $82^{\circ}$ E. and a dip of $36^{\circ} \mathrm{S}$. About 500 feet south of well $12 / 7-3 \mathrm{~J} 1$, 15 feet of calcareous gray clay, under a 6 -foot limestone bed, has a strike of N. $85^{\circ} \mathrm{W}$. and a dip of $47^{\circ} \mathrm{NE}$. Further examination of this area was not possible; however, it appears that the Cache formation has been folded into a syncline, which is covered by younger volcanics to the west.

Due west of wells $12 / 7-1 \mathrm{M} 1,-1 \mathrm{M} 2$, and $-1 \mathrm{M} 3$, along the west bank of Copsey Creek, beds of the Cache formation are in fault con- 
tact with the older sandstones and shales of Cretaceous age. The strike of the fault is N. $80^{\circ} \mathrm{W}$., and the maximum dip is $90^{\circ}$. However, 25 feet north of the fault zone the dip is $71^{\circ} \mathrm{N}$. A measured section of the Cache formation at this locality follows:

Section of the Cache formation of Anderson in the NE $1 / 4 S E_{1 / 4}^{1 /}$ sec. 2, T. 12 N., R. $7 W$. Pliocene and Pleistocene, Cache formation: Feet

Clay and gravel....

Gravel, yellow, cemented.... 2

Clay, limey, with gravel and crossbedded silt_........ 15

Gravel, coarse, moderately cemented.... 7

Clay, limey, white.... 9

Clay, limey, gray 5

Sand, white, cemented................ 2

Clay, gray ....... 5

Fault zone.............. 15

Cretaceous:

Clay

Sandstone _.

Anderson (1936, p. 639) considers the Cache formation to be probably early Pleistocene in age. However, on the basis of lithologic similarity, at least part of the Cache formation may be the western equivalent of the Tehama formation of Sacramento Valley, which is Pliocene in age.

- Along the north edge of Coyote Valley, in secs. 18 and 20, T. 11 N., R. 6 W., Brice (1954) describes outcrops of light-colored cobble gravels, water-laid tuffs, and tuffaceous sands that appear beneath basalt. Similar light-colored water-laid tuffs lie between quartzbearing basalt flows in sec. 15, north of Hells Half Acre. Brice correlates all of these tuffs with the Cache formation. However, the evidence for this correlation does not seem conclusive. Brice (1954) states that the cobble gravels of Coyote Valley are composed mainly of white rhyolite, whereas white rhyolite does not appear in the main area of the Cache formation to the north. These formations could be contemporaneous in part, but they may have been derived from different sources and deposited in different basins.

The yields of most wells in the Cache formation are low, frequently insufficient for domestic needs, but a few wells yield as much as 200 gpm. However, the Cache Formation has been penetrated by only a few wells, and not much is known about its water-bearing properties. Or the basis of the quantity of gravel exposed in the outcrop area of the Cache formation, it is assumed that this formation locally will probably yield moderate quantities of water to irrigation wells.

\section{OLDER ALLUVIUM}

Along the west side of Collayomi Valley and in a large area at the head of Burns Valley, mostly on the north side of the creek, older, 
dissected alluvial deposits form benches 25 to 100 feet above the Recent alluvial fill. (The extent of older and Recent alluvial deposits in the Lower Lake-Middletown area is shown on plate 1.) At most places, these older deposits are maturely dissected and have a brownish-red soil supporting a dense growth of uaderbrush. Where exposed along the creek bottoms, they are composed of bedded sands and gravels. Most of the pebbles and sand grains are oxidized and coated with red iron oxide. At most places the oxide cements the deposit into a fairly compact formation. In Collayomi Valley these deposits are reported to be at least 75 feet thick and appear to represent an older alluvial fill, probably Pleistocene in age. In Burns Valley the thickness of the deposits is unknown. However, they are lithologically indistinguishable from the Cache formation of Anderson, and are mapped as part of that formation.

The deposits are not well sorted and are somewhat indurated or cemented. Thus they would not readily yield water to wells. According to the driller's $\log$ (see p. 25), well 11/7-33L1, which penetrated 100 feet of older alluvium in Collayomi Valley, yields an insufficient supply for domestic needs. However, well 10/7-3P1, which penetrated 77 feet of older alluvium, is reported to yield an adequate domestic supply.

\section{RECENT ALLUVIAL DEPOSITS}

The central parts of all the valleys that were examined are at present being, or recently have been, filled with loose, unconsolidated gravel, sand, and clay. These deposits, derived from the decomposition and erosion of the adjacent mountains, were laid down on alluvial fans of moderate slope, in creek and river channels, on flood plains, and in playas. They are considered Recent in age.

Some valleys contain all types of Recent alluvial deposits, and in others one or more types may be lacking, depending upon the special conditions of deposition in each valley. Along the margins of all the valleys, alluvial fans have been deposited. Ordinarily, these deposits consist of lenticular beds, or tongues, of poorly sorted sand and gravel encased in relatively large amounts of clay and silt. Sand and gravel predominate near the valley margins, and clay and silt predominate in the central parts. In valleys with throughflowing streams, the stream channels ordinarily contain coarse sand and gravel deposits. Flood plain deposits border the stream channels and consist of silt and sand with interbedded gravel. The gravel represents old stream courses, or an interfingering of the flood plain and alluvial-fan deposits. In a closed basin or in any part of a basin without a through-flowing stream, gravel channels are not formed, but the poorly sorted clays, silts, sands, and gravels of the alluvial 
fans grade into the well-sorted clay and silt of a central playa or dry-lake deposits.

Recent alluvial deposits range from only a few inches to slightly more than 200 feet in thickness. With one exception, the alluvium of the valleys is the only important water-bearing material in the Lower Lake-Middletown area.

\section{IGNEOUS ROCKS}

SERPENTINE

The oldest igneous rocks in the area are the ultrabasic intrusions, now wholly serpentinized, in the Franciscan group. They are easily recognized by their greasy luster and green or black color. The small amount of water yielded by these rocks has an unpleasant taste.

\section{VOLCANIC ROCKS}

Many bodies of lava and fragmental volcanic rocks of Pleistocene and Recent age occur in the Lower Lake-Middletown area. Most of them are north of Middletown and have not been tapped by wells, because they underlie a rough untillable land. However, they may absorb appreciable quantities of water from rain and melting snow and store it in joints and fractures. This water discharges from open fractures or at the tops of impermeable zones, and it supplies numerous small springs. Some of the youngest volcanic bodies have changed the movement of surface and ground water by damming preexisting stream valleys. Anderson (1936) and Brice (1954) have differentiated and mapped many flows and bodies of obsidian, scoria, and other fragmental types.

Northeast of Middletown and south of Lower Lake, a series of quartz-bearing olivine basalt flows, which have a gentle southerly dip, rests on older consolidated formations. The flows, mapped by Brice, extend in a band about 3 miles wide from the south side of Excelsior Valley southeastward along the north side of Coyote Valley, at least as far as Putah Creek. The topography is distinctive, characterized by smooth slopes and broad, flat-topped hills, and by the presence of large basalt boulders in the washes. Its areal extent is readily revealed by examination of the map of the Lower Lake quadrangle. Where observed by the writers, the edges of the flows are clearly marked by steep cliffs in which the basalt is exposed. The flows are estimated to be at least 500 feet thick.

Although wells have not been drilled in the area of the flows, springs are numerous. The springs, which yield an adequate supply of water for domestic use on small rauches, are evidently supplied by water in fractures and openings of the flows. 
Several gently sloping lava-capped tablelands are a prominent feature within the outcrop area of the Cache formation east of Clear Lake. Anderson (1936, p. 634-635) describes the lava as basalt that ranges in thickness from 30 to 100 feet. The existing bodies are of small areal extent, but are probably the remnants of a more extensive and continuous flow. Although Anderson believed that the basalt is interbedded with the Cache formation, his evidence is not considered conclusive. The basalt may be unconformable on the Cache formation; if so, it is post-Cache in age. It occurs above the zone of saturation and probably contains little or no water.

Brice (1954) believes that the quartz-bearing olivine basalt north of Coyote Valley and the basalts of the lava caps east of Clear Lake are remnants of several once continuous and nearly contemporaneous flows. He believes that the oldest of these is interbedded with the upper part of the Cache formation.

Bodies of rhyolitic obsidian and silicic dacite (Anderson, 1936, p. 640) and rhyodacite (Anderson, 1936, p. 648) occur south and southeast of Mount Konocti. Anderson believes that the obsidian and silicic dacite are younger than the Cache formation, and that the rhyodacite rests on the obsidian. Where observed by the writers, the rhyolitic obsidian is composed of dense black glassy fractured obsidian, locally called bottle glass. The rhyodacite flow is white and, in places, fragmental; probably, it contains porous zones.

Andesite, basalt, dacite and obsidian occur as numerous isolated small flows and cinder bodies throughout the northern part of the volcanic area. These bodies are considered Recent in age, although all or part of them may be late Pleistocene. Because they are small and form terrane unsuited to agriculture or habitation, wells have not been drilled in them.

\section{GEOLOGIC HISTORY}

The earliest geologic events of the Lower Lake-Middletown area are obscure, but the major events can be determined from work done in regions nearby. In the Late Jurassic(?), sands and muds from a western source accumulated in a shallow geosynclinal sea to become the sedimentary and metamorphic rocks of the Franciscan group and Knoxville formation (Taliaferro, 1943 a, pl. 5A). During and following the period of deposition, these sediments were extensively intruded by ultrabasic igneous rocks in the form of dikes, sills, and flows, which are now wholly sepentinized. The Jurassic was brought to a close throughout the northern California Coast Ranges by uplift and local warping, but the geosyncline was not destroyed.

In the Cretaceous, fine sands and muds accumulated in the shallow sea that was gradually transgressing the geosyncline. These sedi- 
ments became the Shasta series and Chico formation. Near the end of Cretaceous time, presumably, deposition was brought to a close by uplift and folding accompanying a minor orogeny. In earliest Tertiary time the sea again invaded the area, as indicated by the sandstone and shale now known as the Martinez and Tejon formations. During the interval between the deposition of these two units, the sea may have briefly withdrawn; however, evidence of the withdrawal has not been found in the Lower Lake-Middletown area.

At some time following the deposition of the Tejon formation, the land was gradually uplifted and eroded, and the sea withdrew. This episode of erosion evidently continued into the Pliocene, when it was interrupted by a highly complex and (with respect to one valley in comparison with another) varied sequence of events. These included the extrusion of basaltic volcanics, which was apparently restricted to the area south of Excelsior Valley, and the deposition by westwardflowing streams of lacustrine and fluvial clay, silt, sand, and gravel of the Cache formation of Anderson in the area east of Clear Lake. These beds were evidently deposited in a closed or nearly closed basin, which was probably formed by faulting or folding. However, their relationship to the basaltic flows is not known, and specific evidence has not been found regarding the nature and age of the crustal movements that created the basin in which the Cache formation was deposited. Some volcanic activity was taking place in late Cache time, as indicated by the occasional tuff beds in the upper part of the formation. Possibly this activity was related to the extrusion of the basaltic flows farther south.

At about the close of Cache time, basalt was extruded locally to form the lava-capped mesas east of Clear Lake, and renewed crustal movements displaced and deformed the Cache formation. This deformation was locally intense and may have been part of regional movements that elsewhere have been ascribed to early or middle Pleistocene time (Taliaferro, 1943b). Possibly some minor crustal movements have continued to Recent time.

After this deformation, the history of the Lower Lake-Middletown area was predominantly erosional. Around the shores of Clear Lake, erosion was complicated by local extrusion of many types and forms of volcanic rocks. Some of the main drainages may have been established either near the close of Cache time or following the post-Cache time of deformation; others may not have attained their existing pattern until late Pleistocene or Recent time.

In some valleys the progress of erosion was straightforward; in others it was interrupted by minor deformation. Some of the drainages were diverted by piracy or altered by the damming action of late volcanic extrusions. The present configuration of the valleys is 
thought to be the result of stream erosion primarily, although in some the erosion may have been localized in structural depressions. Following a first period of excavation, during which the valleys attained about their present configuration, alluvial deposits were laid down in some valleys. These were partly removed during a second period of erosion, which was terminated by a period of deposition lasting to about the present time. The latest alluvial fill, consisting of clay, silt, sand, and gravel, reached a maximum of more than 200 feet in thickness. Probably the deposition in valleys south of Clear Lake was caused by local downwarping of the basin areas. In valleys farther north, the cause may have been different; in two of these, the latest deposition was brought about by damming of the valleys by lava extrusions.

Late episodes of erosion, deposition, and volcanic extrusion are described in somewhat more detail in the following discussion of individual areas and valleys.

GROUND WATER CONDITIONS BY INDIVIDUAL VALLEYS

\section{COLLAYOMI AND LONG VALLEYS}

\section{PHYSICAL AND CULTURAL Features}

Collayomi and Long Valleys are arms of the same depression in the headward part of the Putah Creek drainage. (See pl. 1.) Collayomi Valley, the larger of the two, includes an arm that extends southward along St. Helena Creek. Middletown, about 5 miles north of the Napa-Sonoma County line, is in the central part of the valley. The total drainage area of streams entering Collayomi Valley between the head of the valley and the junction of Putah Creek and its principal tributary, St. Helena Creek, is about 54 square miles. Of this area, the alluvial plain comprises about 4 square miles. Long Valley, wbich joins Collayomi Valley north of Middletown, has a drainage area of about 10 square miles with an alluvial plain of about $2 \% 4$ square miles; perennial streams do not enter it.

State Highway 29, from Calistoga, traverses the full length of Collayomi Valley along its western side. State Highway 53 branches from Highway 29 in Collayomi Valley southwest of Middletown, goes through Middletown, crosses the lower part of Long Valley, and continues to Clear Lake.

Development of ground water in Collayomi Valley is confined to dug and drilled domestic wells; although of small production, they are adequate for most domestic needs and a small amount of irrigation. The town of Middletown is supplied by private wells. Several dug wells, which yield less than $50 \mathrm{gpm}$, furnish water for a few acres $323058-55-4$ 
of alfalfa or garden. Each of five sumps dug in the gravel channel of St. Helena Creek yield an estimated 200 to $500 \mathrm{gpm}$ and furnish irrigation water for about 100 acres of alfalfa. One farmer irrigates his land by flooding, but for all other irrigation, aluminum pipe and sprinklers are used. Except for pasture irrigation near the old Mirabel mine at the extreme south end of the valley, water is not pumped directly from St. Helena or Putah Creeks.

Development of ground water in Long Valley is limited to domestic wells that are less than 50 feet deep and of low yield. Well 10/6-7C1, which is 102 feet deep, penetrated serpentine at 33 feet; well 10/71D1, which is 241 feet deep, has not been used (see p. 25).

\section{GEOLOGY}

The drainage area of Collayomi and Long Valleys is underlain by non-water-bearing sandstones, shales, and serpentines of the Franciscan group and Knoxville formation. These rocks completely surround the alluvial plains. In a narrow channel about 2 miles below the junction of Putah and St. Helena Creeks, where Putah Creek enters Coyote Valley, the alluvium is absent and almost all drainage out of Collayomi and Long Valleys comes to the surface.

The detailed physiographic history of these valleys is not know, but some events have been deciphered. The pattern of the alluvium of Collayomi, Long, and Coyote Valleys is so irregular that these valleys are considered to be predominantly erosional in origin. Also, they are crudely alined in a northwest-southeast direction. For this, and for one other reason discussed below, the valleys are believed to be structural depressions that were partly downwarped during deposition of the alluvium.

Evidence of warping may be found in the fact that consolidated rock crops out in the bed of Putah Creek in the SE $1 / 4$ sec. 15, T. 11 N., R. $7 \mathrm{~W}$. at an altitude of about 1,025 feet, and that well $11 / 7-35 \mathrm{E} 1$ (pl. 1), about 3 miles upstream at an altitude of 1,070 feet, failed to penetrate hard rock at a depth of 151 feet. Apparently bedrock lies below an altitude of 920 feet at the well. Therefore, the bedrock near the junction of Collayomi and Long Valleys is at least 100 feet lower than it is at the outlet of these valleys, several miles downstream. The altitude of this point is also lower than any point on the drainage divide. Thus, it is believed that the central part of Collayomi and Long Valleys has been warped downward, and that this is the cause of the alluvial filling.

The abrupt change in course of Putah Creek at its junction with Big Canyon Creek, in sec. 15, T. 11 N., R. 27 W., strongly suggests piracy. At one time Big Canyon Creek, which apparently flowed along the present course of Putah Creek into Collayomi and Long 
Valleys, was captured by Putah Creek, which was working headward from the northwest end of Coyote Valley. As a result, the drainage in the reach between Middletown and secs. 15 and 22 was reversed. Evidence that the diversion took place recently was not found; probably it occurred early in the physiographic development of the valleys when the stream grades were 100 or more feet higher than at present.

The lithology of the alluvium of Collayomi and Long Valleys bears on this problem. If Big Canyon Creek flowed into the depression during deposition of the alluvium, the deposits at depth would be those of a closed basin in a relatively moist climate-chiefly finegrained clay and silt (probably lake-bed deposits), with minor amounts of gravel. The beds might be continuous and uniform over a wide area. On the other hand, if Putah Creek drained the valley, even if only intermittently, while the alluvium was being deposited, the beds would tend to be relatively fine grained, but they would probably contain a bigher proportion of sand and silt, the strata probably would be lenticular, and occasional lenses of gravel might occur. If drained by Putah Creek, the ground-water storage capacity would be greater, and the opportunity for replenishment, better. Unfortunately, logs were obtained for only a few wells. The most detailed log is for well 10/7-1D1 (p. 25) in Long Valley. It shows the presence of much gravel to a depth of 107 feet, then a deposit of clay (probably a lake or swamp deposit) with one 2-foot bed of loose gravel to a depth of 230 feet, where serpentine is reported.

The change from fine-grained to coarse-grained deposits may coincide with the date of piracy. However, this evidence does not in itself prove that Collayomi and Long Valleys were a closed depression into which streams flowed from all sides. If Putah Creek flowed through Collayomi Valley throughout the period of deposition of the alluvium, as it does now, its deposits would have blocked the lower end of Long Valley, which has little or no drainage from the southeast, and would have created more or less continuous swamp or lake conditions in Long Valley. The deposits in Long Valley would probably be finegrained under any bypothesis of drainage; indeed, the productivity of most wells seems to bear this out. ${ }^{1}$

A low terrace, as much as half a mile wide, occurs in two areas along the southwestern side of Collayomi Valley. The soil and alluvium exposed in shallow road cuts are yellowish brown, and the deposits are classed as older alluvium. Well 11/7-33L1, drilled in

1 Since completion of fleld work in this area a well drilled near Middletown in the SE14 sec. 34, T. 11 N., R. 7 W. was reported to penetrate alternating beds of gravel, cemented gravel, and blue clay to a depth of 147 feet, dense blue clay to 240 feet, and what is evidently bedrock between 240 and 297 feet. The 93 feet of dense blue clay may represent early lake or swamp deposits. 
this material, is reported to have penetrated sand and sandy clay with an insufficient yield of water for domestic use. (See p. 25.) Cuttings around the hole at the well resemble fragments of sandstone. Some or all of the material below a depth of 38 feet may be consolidated rock. Thus, the older alluvium may be only the thin veneer of a cut terrace.

Nearly all of the ground water in Collayomi and Long Valleys occurs in the alluvium deposited on alluvial fans of low slope, in gravel channels of Putah Creek, St. Helena Creek, and their tributaries, and locally, perhaps, in lake and swamp deposits. Except for the gravel channels, which are probably restricted to Collayomi Valley, it is believed that these alluvial deposits consist mostly of fine-grained material. Wells on the alluvial plain are of low yield, and neither clean nor coarse gravels have been reported by the owners of drilled wells or by well drillers. At present, most of Long Valley is a nearly level plain. For this reason, and because the drainage into the valley is too small to carry coarse material, the deposits immediately underlying the plain must be chiefly clay and silt. It is reported that several "dry holes" have been drilled in Long Valley. One of these, a dug pit about 15 feet deep, was observed by the writers; here the material underlying the alluvial plain was found to be predominantly clay or tight material with thin lenses of gravel. The log of well $10 / 7-1 \mathrm{D} 1$ (p. 25) indicates that at this location the valley fill is almost wholly clay from a depth of 64 to 230 feet.

In Collayomi Valley, on the other hand, the alluvium contains some coarse gravel channels. Along the channels of Putah and St. Helena Creeks the visible shallow deposits range from fine sand to coarse cobbles and boulders, but clean coarse gravels predominate. To date nearly all of the ground water developed in Collayomi and Long Valleys that is in excess of the minimum domestic needs is pumped from sumps in the gravel channel of St. Helena Creek. The shallowest is about 10 feet deep, and its bottom is in the Franciscan group. The deepest is about 16 feet deep, its bottom being in gravel. Each sump is estimated to yield from 200 to $500 \mathrm{gpm}$. It is likely that similar deposits might be found at greater depth in the northwestern and southern arms of Collayomi Valley, but the deposits bave not been adequately tested by existing wells. If one of the older channels of St. Helena or Putah Creeks were penetrated, the yield would probably be comparable to the yield of the sumps. ${ }^{2}$ Most of the present wells are near the valley margins and apparently

\footnotetext{
2 Since completion of field work in this area, two wells were drilled north of the Middletown High School for E. F. Davies. They are reported to be 145 and 153 feet deep, and to penetrate coarse water-bearing gravel. During the summer of 1951 the 145 -foot well was reported to yield 1,200 gpm with a 30-foot drawdown after 10 hours of pumping, and the 153 -foot well was reported to yield $400 \mathrm{gpm}$ with a 50 -foot drawdown after 9 hours of pumping.
} 
penetrate poorly sorted alluvial-fan deposits from which the yields are small.

The maximum known thickness of alluvium in Collayomi and Long Valleys is 230 feet at well 10/7-1D1, as reported by the owaer. The alluvium is probably as thick or thicker at the confluence of the alluvial plains of the two valleys. Well $11 / 7-35 \mathrm{E} 1$, drilled to a depth of 151 feet in this area, did not penetrate bedrock.

\section{Logs of wells in Collayomi and Long Valleys}

Well 10/6-7C1, Shaw

[At edge of alluvial plain in Long Valley. Reported by driller]

\begin{tabular}{|c|c|c|}
\hline & $\begin{array}{c}\text { Thickness } \\
\text { (feet) }\end{array}$ & $\begin{array}{l}\text { Depth } \\
\text { (feet) }\end{array}$ \\
\hline $\begin{array}{l}\text { Alluvium: } \\
\text { Soil, brown-red. } \\
\text { Silt and decomposed serpentine }\end{array}$ & $\begin{array}{r}30 \\
3\end{array}$ & $\begin{array}{l}30 \\
33\end{array}$ \\
\hline $\begin{array}{l}\text { Franciscan group: } \\
\text { Serpentine, }\end{array}$ & 69 & 102 \\
\hline
\end{tabular}

Well 10/7-1D1, Elmer Miller

[On alluvial plain of Long Valley. Reported by owner]

\begin{tabular}{|c|c|c|}
\hline & $\begin{array}{c}\text { Thickness } \\
\text { (feet) }\end{array}$ & $\begin{array}{l}\text { Depth } \\
\text { (feet) }\end{array}$ \\
\hline $\begin{array}{l}\text { Alluvium: } \\
\text { Soil } \\
\text { Gravel, some water. } \\
\text { Clay } \\
\text { Gravel, water, } \\
\text { Clay and mud } \\
\text { Gravel and clay, alternating } \\
\text { Clay, sticky, various colors } \\
\text { Gravel, loose, water } \\
\text { Clay, various colors. } \\
\text { Franciscan group: }\end{array}$ & $\begin{array}{r}5 \\
10 \\
17 \\
32 \\
6 \\
37 \\
90 \\
2 \\
31 \\
11\end{array}$ & $\begin{array}{r}5 \\
15 \\
32 \\
64 \\
70 \\
107 \\
197 \\
199 \\
230 \\
241\end{array}$ \\
\hline
\end{tabular}

Well 10/7-3L1, W. P. Miller

[On alluvial plain of Collayomi Valley half a mile southeast of Middletown. Reported by owner]

\begin{tabular}{l|r|r}
\hline & $\begin{array}{c}\text { Thickness } \\
\text { (feet) }\end{array}$ & $\begin{array}{r}\text { Depth } \\
\text { (feet) }\end{array}$ \\
\hline $\begin{array}{c}\text { Alluvium: } \\
\text { Soil and gravel }\end{array}$ & & 13 \\
7 & 13 \\
\hline
\end{tabular}

Well 11/7-33L1, Otto Stien

[On low bench about 1.5 miles northwest of Middletown in Collayomi Valley. From driller's record]

\begin{tabular}{|c|c|c|}
\hline & $\begin{array}{c}\text { Thickness } \\
\text { (feet) }\end{array}$ & $\begin{array}{l}\text { Depth } \\
\text { (feet) }\end{array}$ \\
\hline $\begin{array}{l}\text { Older alluvium: } \\
\text { Soil, brown, and gravel } \\
\text { Sand, yellow } \\
\text { Clay, sandy, blue. }\end{array}$ & $\begin{array}{l}13 \\
25 \\
62\end{array}$ & $\begin{array}{r}13 \\
38 \\
100\end{array}$ \\
\hline
\end{tabular}




\section{GROUND WATER}

In the Lower Lake-Middletown area, large amounts of ground water occur only in the alluvium, and with few exceptions all the wells observed penetrate the alluvium. Depths to water are shallow; in mid-summer they average less than 15 feet below the land surface. (See table 2.) However, if greater development of ground water occurs in the valleys, summer water levels would be drawn down to greater depths. The position of winter static levels would depend on the relative amount of pumpage and replenishment each season. Periodic water-level measurements in observation wells follow. Miscellaneous data are given in table 2.

10/7-1D1. Elmer Miller. Long Valley. About 1 mile due east of Middletown, 0.85 mile southeast of State Highway 53 along Long Valley road, 350 feet north-northeast of dwelling, 190 feet north of concrete ford in slough trough, 15 feet northwest of dirt road in field. Measuring point, top of casing at weld,1.0 foot above land-surface datum and about 1,075 feet above sea level.

Water levels, in feet below land-surface datum, 1950-52

\begin{tabular}{|c|c|c|c|c|c|}
\hline Date & $\begin{array}{l}\text { Water } \\
\text { level }\end{array}$ & Date & $\begin{array}{l}\text { Water } \\
\text { leveI }\end{array}$ & Date & $\begin{array}{l}\text { Water } \\
\text { level }\end{array}$ \\
\hline $\begin{array}{l}\text { 1950 } \\
\text { July } 11 \ldots \\
\text { Aug. } 8 \\
\text { Aug. } 22 \\
\end{array}$ & $\begin{array}{l}8.13 \\
8.84 \\
9.13\end{array}$ & $\begin{array}{l}\text { Oct. } 11 \text { (1950-Con. } \\
\text { Nov. } 7- \\
\text { Dec. } 27\end{array}$ & $\begin{array}{l}9.82 \\
8.56 \\
4.21\end{array}$ & $\begin{array}{l}\text { Apr. } 26 \\
\text { Oct. } 1051 \\
\text { Mar. 26 } 1952 \\
\end{array}$ & $\begin{array}{r}5.65 \\
10.42 \\
4.15\end{array}$ \\
\hline
\end{tabular}

10/7-10B1. James Silva. Collayomi Valley. About 1.5 miles along highway south of Middletown, and about 0.12 mile northeast of State Highway 29 at end of J. Agapoff's lane, 50 feet north of Silva-Agapoff fence line. Measuring point, center of U. S. G. S. copper washer on south side of 12 -inch pole over sump, level with land-surface datum and about 1,150 feet above sea level.

Water levels, in feet below land-surface datum, 1950-52

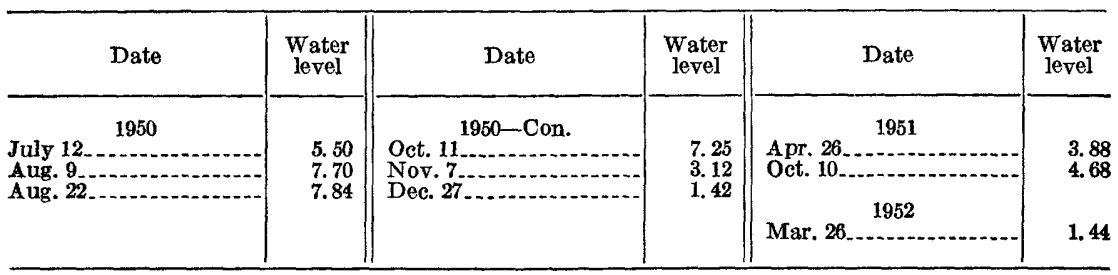


11/7-33L1. Otto Stien. Collayomi Valley. About 1.5 miles northwest of Middletown, 0.15 mile north of road intersection, 140 feet northeast of State Highway 29. Measuring point, top of casing at rivets, 0.8 foot above land-surface datum and about 1,130 feet above sea level.

Water levels, in feet below land-surface datum, 1949-52

\begin{tabular}{|c|c|c|c|c|c|}
\hline Date & $\begin{array}{l}\text { Water } \\
\text { level }\end{array}$ & Date & $\begin{array}{l}\text { Water } \\
\text { level }\end{array}$ & Date & $\begin{array}{l}\text { Water } \\
\text { level }\end{array}$ \\
\hline Oct. 14 & 125.9 & Aug. 9 & 20.81 & Apr. 26 1951 & 11.08 \\
\hline $\begin{array}{l}\text { Mar. } 29.1950 \\
\text { June } 14-11 \\
\text { July } 11\end{array}$ & $\begin{array}{l}15.9 \\
12.77 \\
16.82\end{array}$ & $\begin{array}{l}\text { Sept. } 26 \\
\text { Oct. } 11 \\
\text { Nov. } 7 \\
\text { Dec. } 27\end{array}$ & $\begin{array}{r}125.7 \\
26.78 \\
28.19 \\
5.87\end{array}$ & Mar. 26 & 5.30 \\
\hline
\end{tabular}

1 Measurement by U. S. Bureau of Reclamation.

11/7-35E1. C. H. Bailey. Collayomi Valley. About 0.8 mile northeast of Middletown, about 0.15 mile northwest of State Highway 53, 100 feet northwest of large oak tree, 60 feet northwest of small dwelling, 20 feet northwest of Bailey's private road, on concrete slab. Measuring point, top of casing at weld, 1.0 foot above land-surface datum and about 1,070 feet above sea level.

Water levels, in feet below land-surface datum, 1950-52

\begin{tabular}{|c|c|c|c|c|c|}
\hline Date & $\begin{array}{l}\text { Water } \\
\text { level }\end{array}$ & Date & $\begin{array}{l}\text { Water } \\
\text { level }\end{array}$ & Date & $\begin{array}{l}\text { Water } \\
\text { level }\end{array}$ \\
\hline $\begin{array}{l}\text { Mar. } 30 \\
\text { Muly } 13 \\
\text { Aug. } 90 \\
\text { Aug. } 22 \\
\end{array}$ & $\begin{array}{r}16.1 \\
29.07 \\
9.67 \\
29.77\end{array}$ & $\begin{array}{l}\text { Sept. } 26 . .60-\text { Con. } \\
\text { Oct. } 9 \\
\text { Nov. } 7 \\
\text { Dec. } 27\end{array}$ & $\begin{array}{r}110.1 \\
10.26 \\
8.28 \\
6.08\end{array}$ & $\begin{array}{l}\text { Apr. 26 } \\
\text { Oct. 10 } \\
\text { Mar. 26. } 1952 \\
\end{array}$ & $\begin{array}{r}6.90 \\
10.25 \\
6.69\end{array}$ \\
\hline
\end{tabular}

1 Measurement by U. S. Bureau of Reclamation.

2 Pump operating in sump 11/7-35E2.

11/7-35E2. C. H. Bailey. Collayomi Valley. About 0.8 mile northeast of Middletown. Sump 275 feet northwest of 11/7-35E1. Measuring point, center of U. S. G. S. copper washer at end of central 2-inch by 6-inch pump support, level with land-surface datum and about 1,070 feet above sea level.

Water levels, in feet below land-surface datum, 1950-5\%

\begin{tabular}{|c|c|c|c|c|c|}
\hline Date & $\begin{array}{l}\text { Water } \\
\text { level }\end{array}$ & Date & $\begin{array}{l}\text { Water } \\
\text { level }\end{array}$ & Date & $\begin{array}{l}\text { Water } \\
\text { level }\end{array}$ \\
\hline $\begin{array}{l}\text { July } 13.50 \\
\text { Aug. } 9 \\
\text { Aug. } 22 \\
\end{array}$ & $\begin{array}{r}18.52 \\
7.97 \\
19.42\end{array}$ & $\begin{array}{l}\text { Oct. } 9250-\text { Con. } \\
\text { Nov. } 7- \\
\text { Dec. } 27\end{array}$ & $\begin{array}{l}8.64 \\
6.42 \\
4.34\end{array}$ & $\begin{array}{c}1951 \\
\text { Apr. 26 } \\
\text { Oct. 10. } \\
\text { Mar. 26 } \\
\end{array}$ & $\begin{array}{r}5.12 \\
8.63 \\
4.34\end{array}$ \\
\hline
\end{tabular}

1 Pump operating in sump. 
28 GROUND WATER, LOWER LAKE-MIDDLETOWN AREA, CALIF.

\begin{tabular}{|c|c|c|c|c|c|c|c|c|c|}
\hline 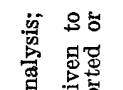 & & 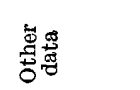 & & & $\mu$ & & & $\begin{array}{l}3 \\
5\end{array}$ & \\
\hline 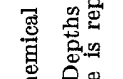 & & 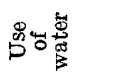 & & 'D & & $\begin{array}{l}\vdots \\
0 \\
0\end{array}$ & is & 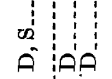 & $\begin{array}{c}\vdots \\
0 \\
0 \\
0\end{array}$ \\
\hline 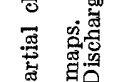 & & 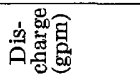 & & & & & & & \\
\hline 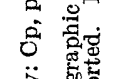 & & 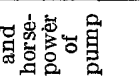 & & & & $\frac{1}{5}$ & & 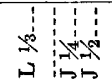 & \\
\hline 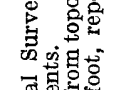 & & 政国 & & & & & & & \\
\hline 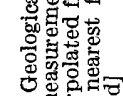 & $\vec{D}$ & 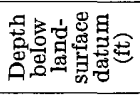 & & $\begin{array}{l}\text { 8nc } \\
\text { rigio } \\
\text { - }\end{array}$ & 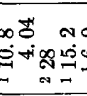 & 0 & T1- & 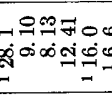 & 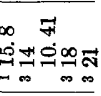 \\
\hline 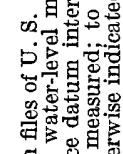 & 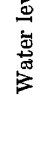 & 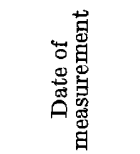 & & 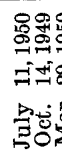 & 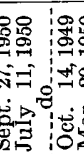 & $\begin{array}{ll} & \\
0 \\
0\end{array}$ & 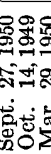 & 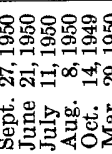 & 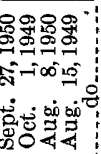 \\
\hline 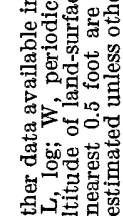 & 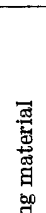 & 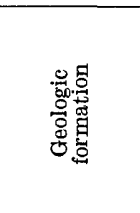 & 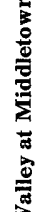 & 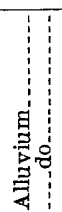 & 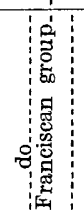 & 章 & & 量。 & $\begin{array}{c:}\vdots \\
\vdots \\
\vdots \\
⿱ 亠 䒑\end{array}$ \\
\hline 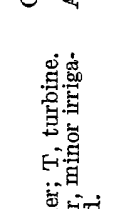 & 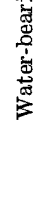 & 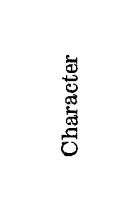 & 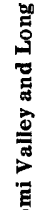 & & 宽 & 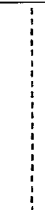 & 豙 & & \\
\hline 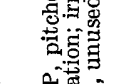 & & 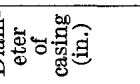 & $\frac{8}{\bar{\theta}}$ & 8 & $\infty \infty \varnothing$ & 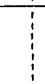 & & 我号: & $\mathfrak{N}$ \\
\hline 可: & & 足语 & & 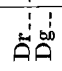 & 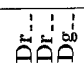 & ค' & $\stackrel{i}{a}$ & 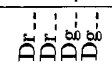 & $\stackrel{1}{\circ}$ \\
\hline 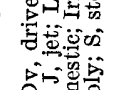 & & 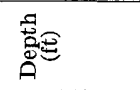 & & \begin{tabular}{l|l|}
0 \\
\multirow{2}{*}{$:$}
\end{tabular} & $\begin{array}{l}0 \\
\text { 매용 }\end{array}$ & $\begin{array}{l}0 \\
\text { के }\end{array}$ & : & 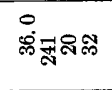 & $\stackrel{\circ}{\circ}$ \\
\hline 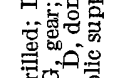 & & 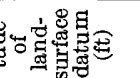 & & $\begin{array}{l}28 \% \\
=7-7\end{array}$ & 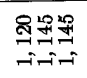 & 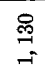 & $\stackrel{8}{\stackrel{9}{9}}$ & 옹영888 & $\stackrel{8}{9}$ \\
\hline A & & 喓要要 & & & 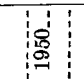 & 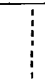 & & 足 & 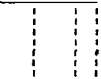 \\
\hline 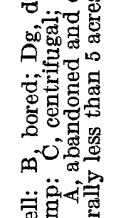 & & 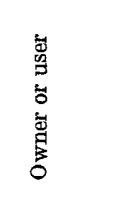 & & 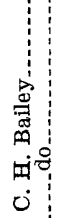 & $\begin{array}{l}1 \\
1 \\
0 \\
0 \\
0 \\
0 \\
0 \\
0\end{array}$ & $\begin{array}{l}D_{0}^{\prime} \\
e_{0}^{0} \\
\sum_{\Sigma} \\
\dot{\Sigma}\end{array}$ & $\begin{array}{l}\dot{1} \\
\dot{0} \\
0 \\
0 \\
\dot{0} \\
\dot{3} \\
\dot{2}\end{array}$ & 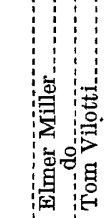 & 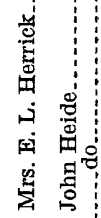 \\
\hline 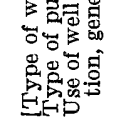 & & 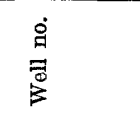 & & 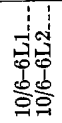 & 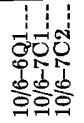 & $\begin{array}{c}\vdots \\
\vdots \\
0 \\
0 \\
0 \\
0 \\
0\end{array}$ & $\begin{array}{l}1 \\
\vdots \\
0 \\
0 \\
0 \\
0 \\
0\end{array}$ & 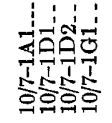 & 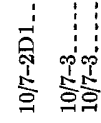 \\
\hline
\end{tabular}




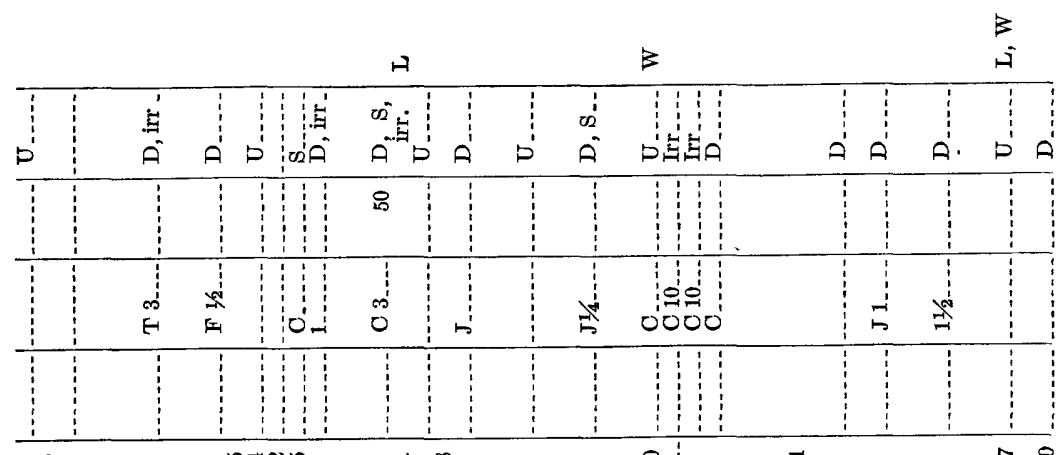

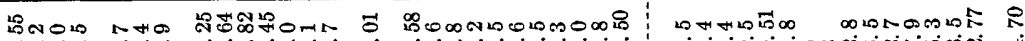

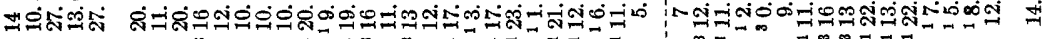

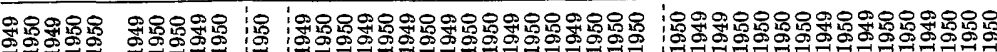

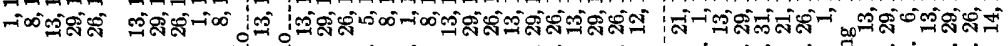

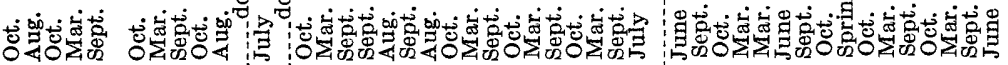

\begin{tabular}{|c|c|c|c|c|c|c|c|c|c|c|}
\hline 差 & & 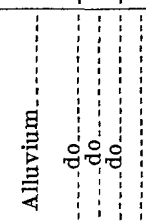 & 量: & & & & 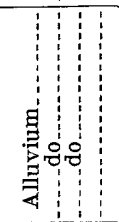 & 童 & & 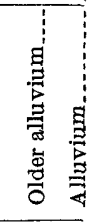 \\
\hline & & & 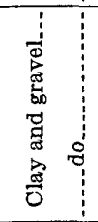 & & & & & & & 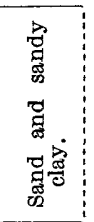 \\
\hline$\infty$ & $\infty$ & 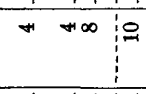 & $\div$ & $\infty$ & 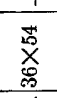 & 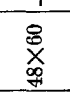 & e气 & $\infty$ & & $\infty$ \\
\hline $\begin{array}{ll}1 \\
0\end{array}$ & $\dot{\Delta}$ & 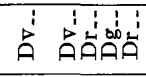 & 定 & $\dot{\Delta}$ & $\stackrel{1}{1}$ & $\stackrel{1}{\circ}$ & 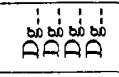 & $\stackrel{1}{\circ}$ & & ¿ \\
\hline 足 吕 & $\hat{\mathfrak{a}}$ & 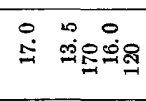 & $\begin{array}{ll}0 & 0 \\
\stackrel{\infty}{9} & \stackrel{\dot{m}}{9}\end{array}$ & $\mathrm{~N}$ & 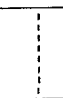 & 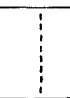 & 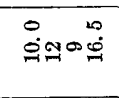 & สิ ฮ્ఝ & & 迥 \\
\hline$\underset{8}{8}$ & $\stackrel{9}{=}$ & 용 $888 \%$ & $₫ \underset{\$}{\sharp}$ & $\stackrel{8}{\stackrel{9}{9}}$ & $\underset{9}{9}$ & I & 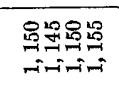 & $\underset{7}{\stackrel{8}{9}}$ & $\underset{-1}{8}$ & \\
\hline & & $\begin{array}{r}1 \\
\\
0 \\
\end{array}$ & 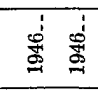 & & & ! & : & & & 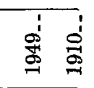 \\
\hline 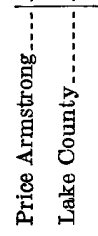 & 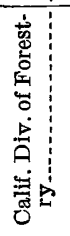 & 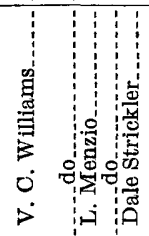 & 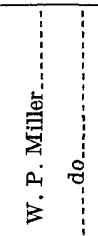 & 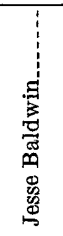 & 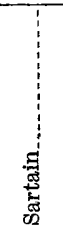 & 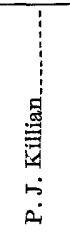 & 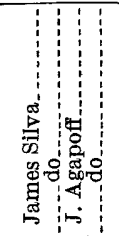 & 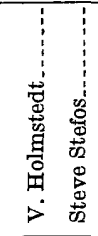 & 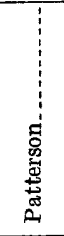 & 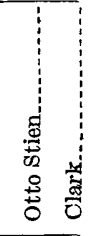 \\
\hline $\begin{array}{ll}\frac{1}{4} \\
\frac{1}{4} \\
\frac{1}{4} \\
\frac{p}{0} \\
\frac{1}{2} \\
\frac{1}{2}\end{array}$ & $\begin{array}{l}1 \\
0 \\
0 \\
0 \\
0 \\
0\end{array}$ & 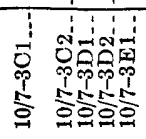 & 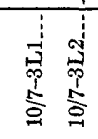 & $\begin{array}{l}\frac{1}{0} \\
\frac{0}{0} \\
\frac{1}{0}\end{array}$ & 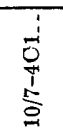 & 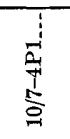 & 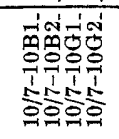 & 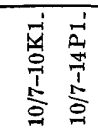 & $\begin{array}{l}\frac{1}{4} \\
\frac{1}{1} \\
\frac{1}{9} \\
0\end{array}$ & 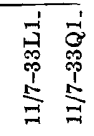 \\
\hline
\end{tabular}


GROUND WATER, LOWER LAKE-MIDDLETOWN AREA, CALIF.

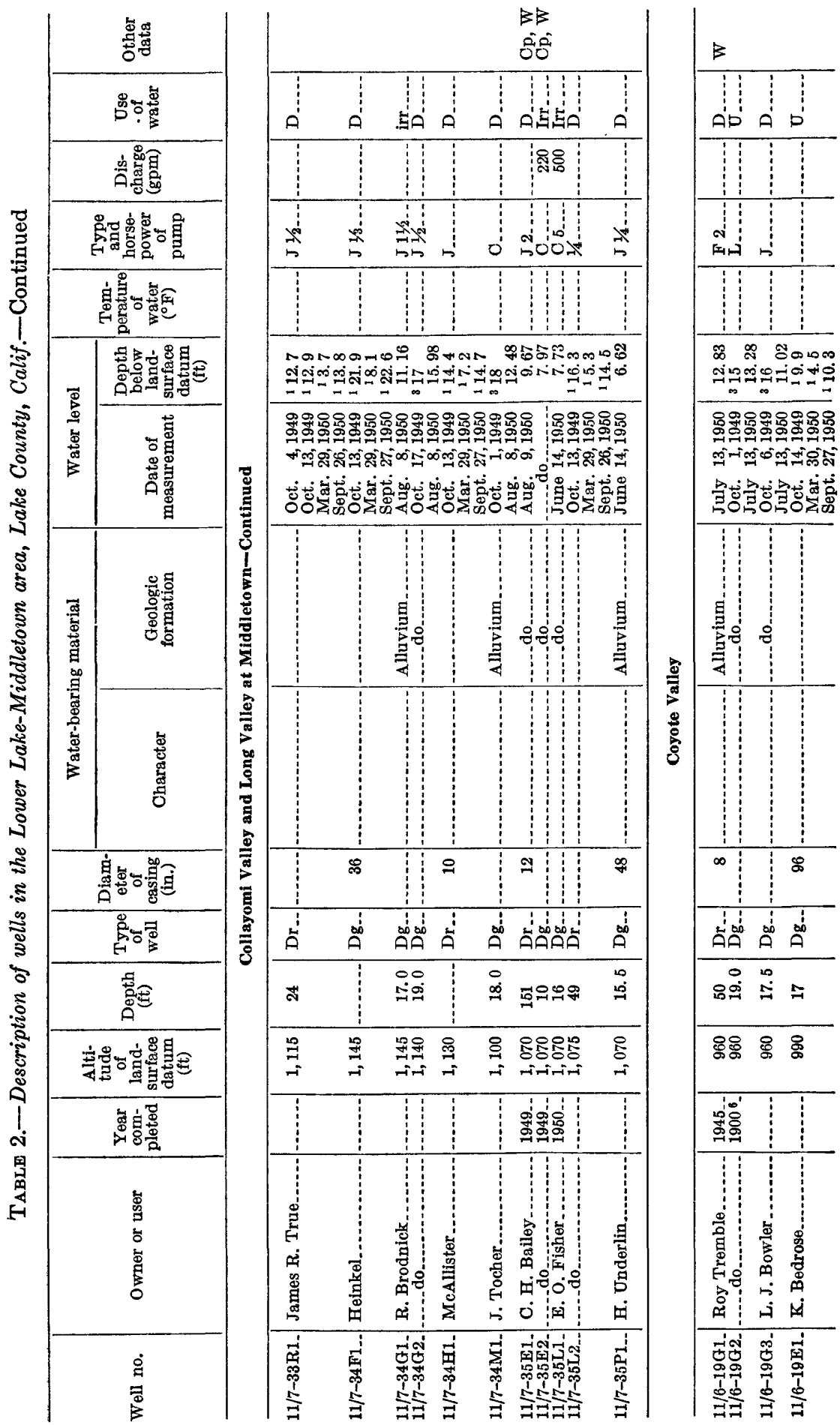




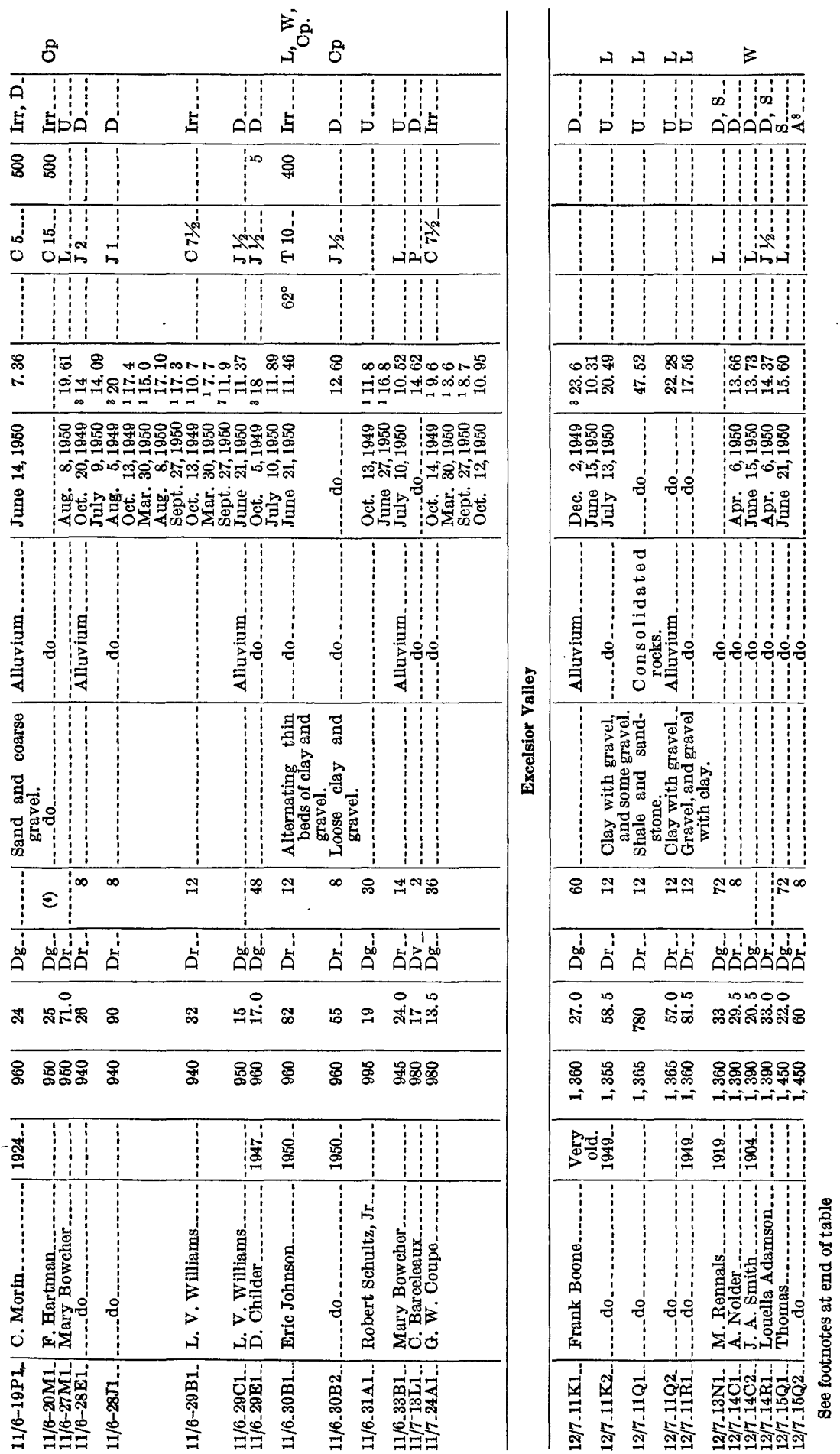


GROUND WATER, LOWER LAKE-MIDDLETOWN AREA, CALIF.

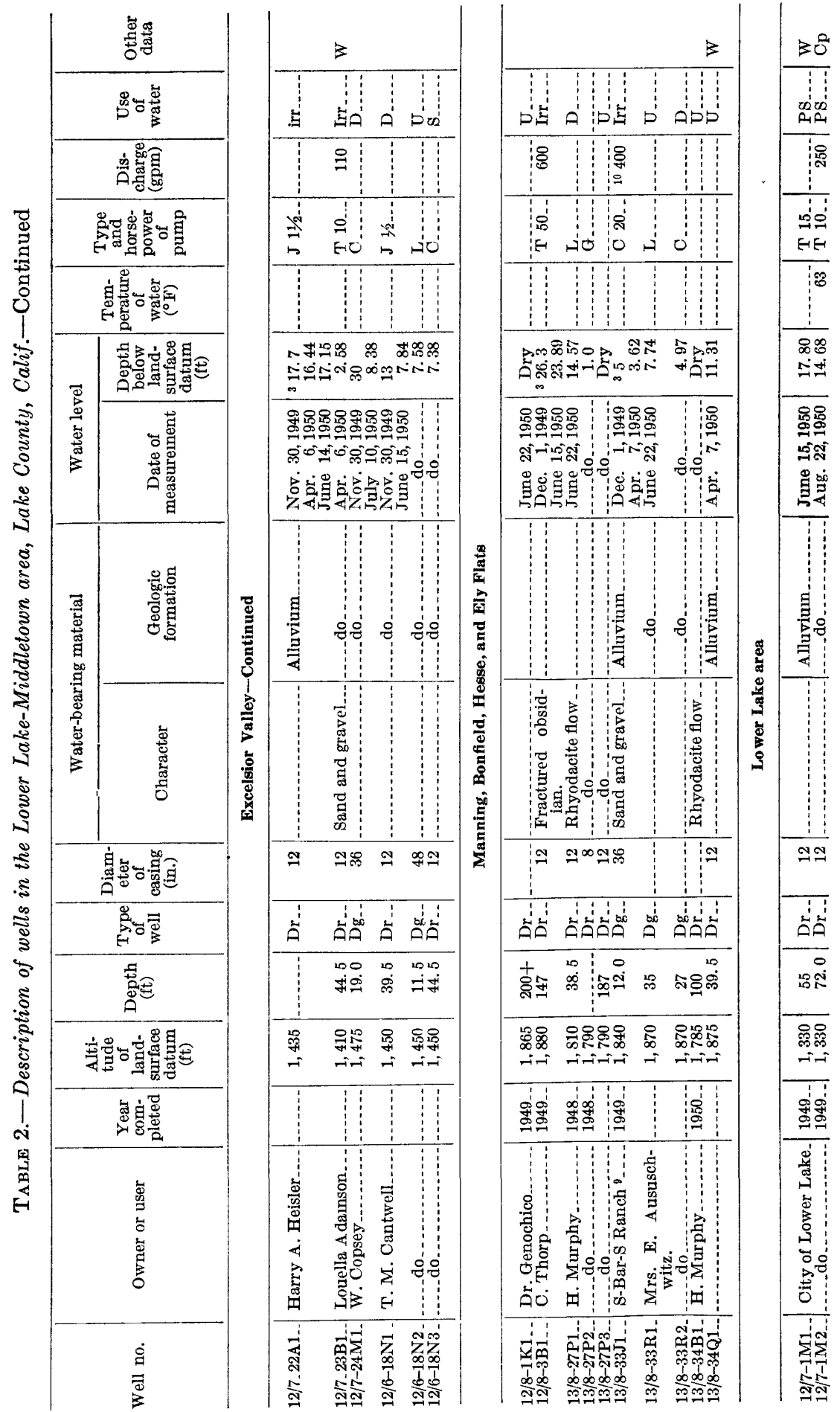




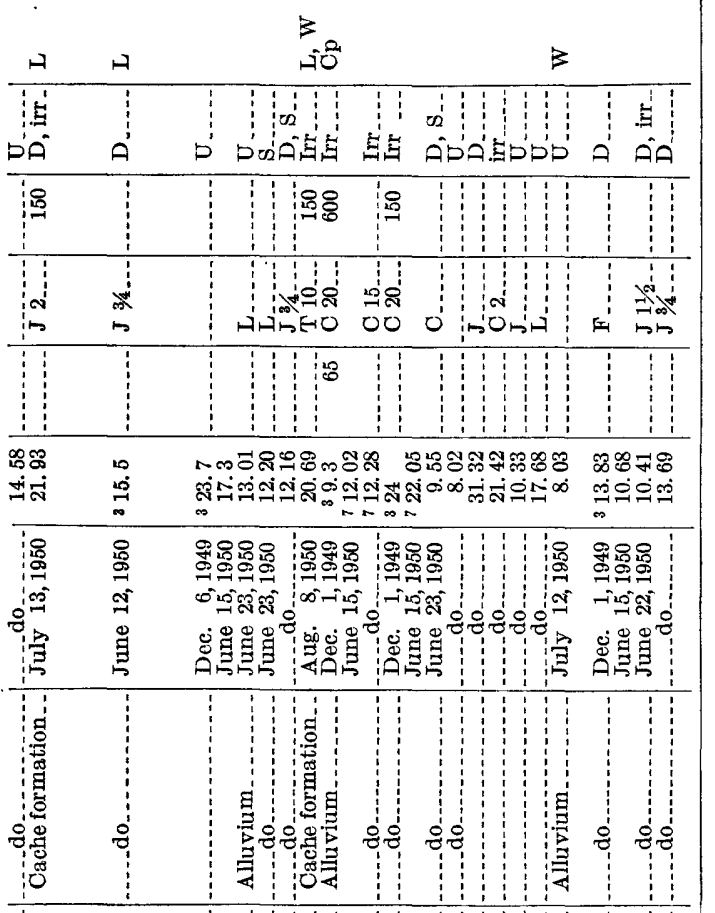

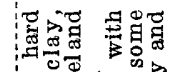

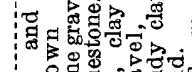

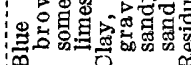

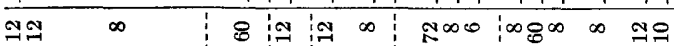

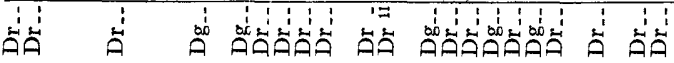

10 no 0 is 00000 o

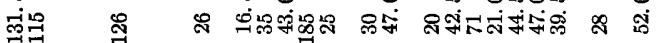

⿸尸𠄌

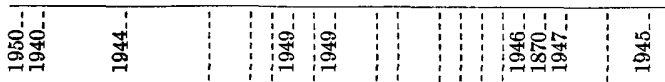

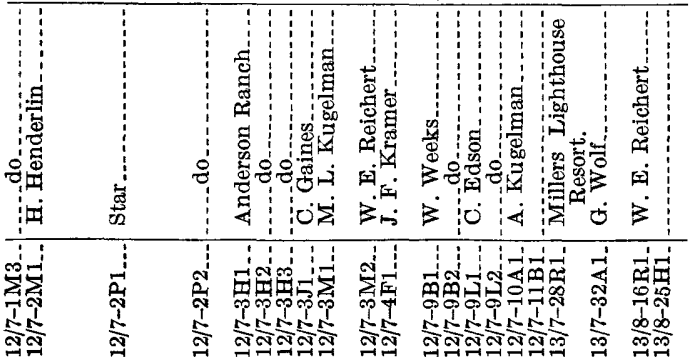

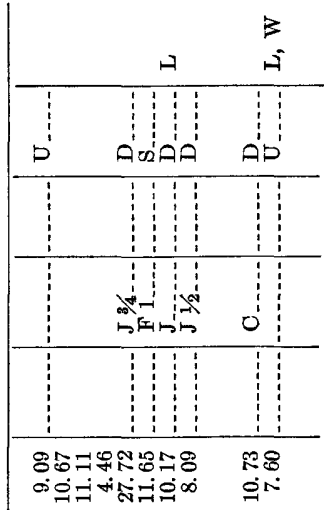

양잉영영

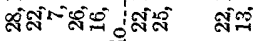

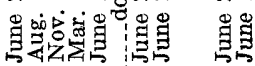

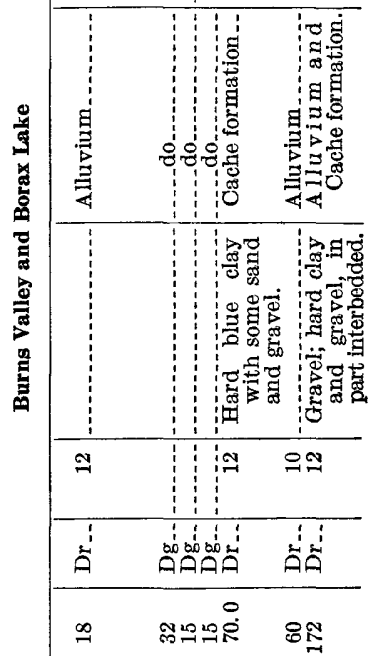

\begin{tabular}{|c|c|c|}
\hline శ్ & 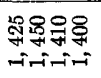 & 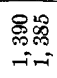 \\
\hline & & \\
\hline $\begin{array}{l}\text { 葛 } \\
\text { 量 } \\
\text { 㽞 }\end{array}$ & 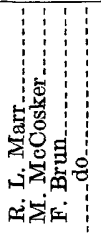 & 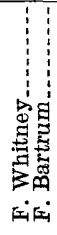 \\
\hline$\underset{\frac{1}{0}}{\frac{1}{2}}$ & 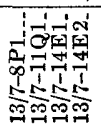 & 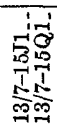 \\
\hline
\end{tabular}


GROUND WATER, LOWER LAKE-MIDDLETOWN AREA, CALIF.

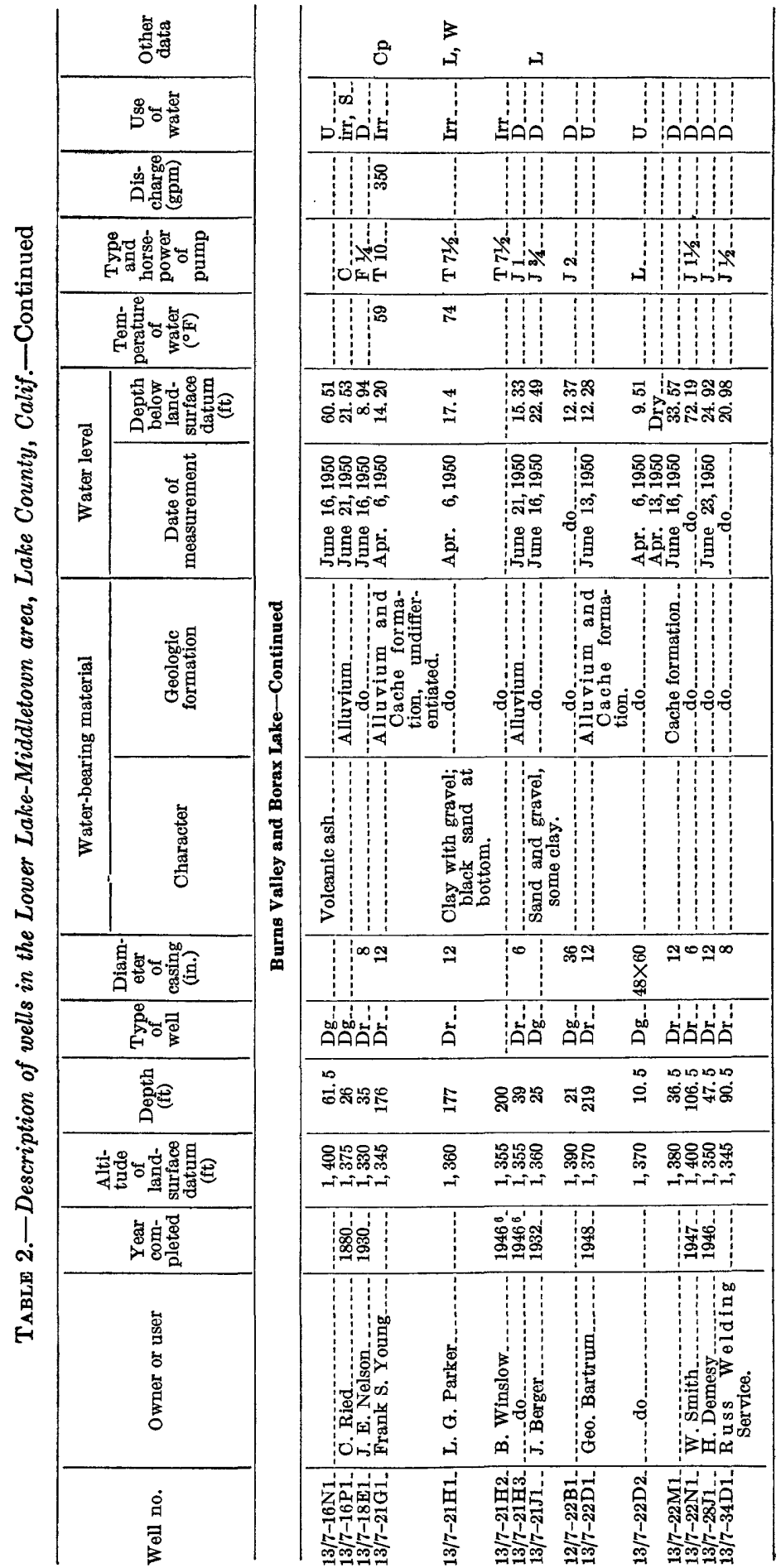


DESCRIPTION OF WELLS

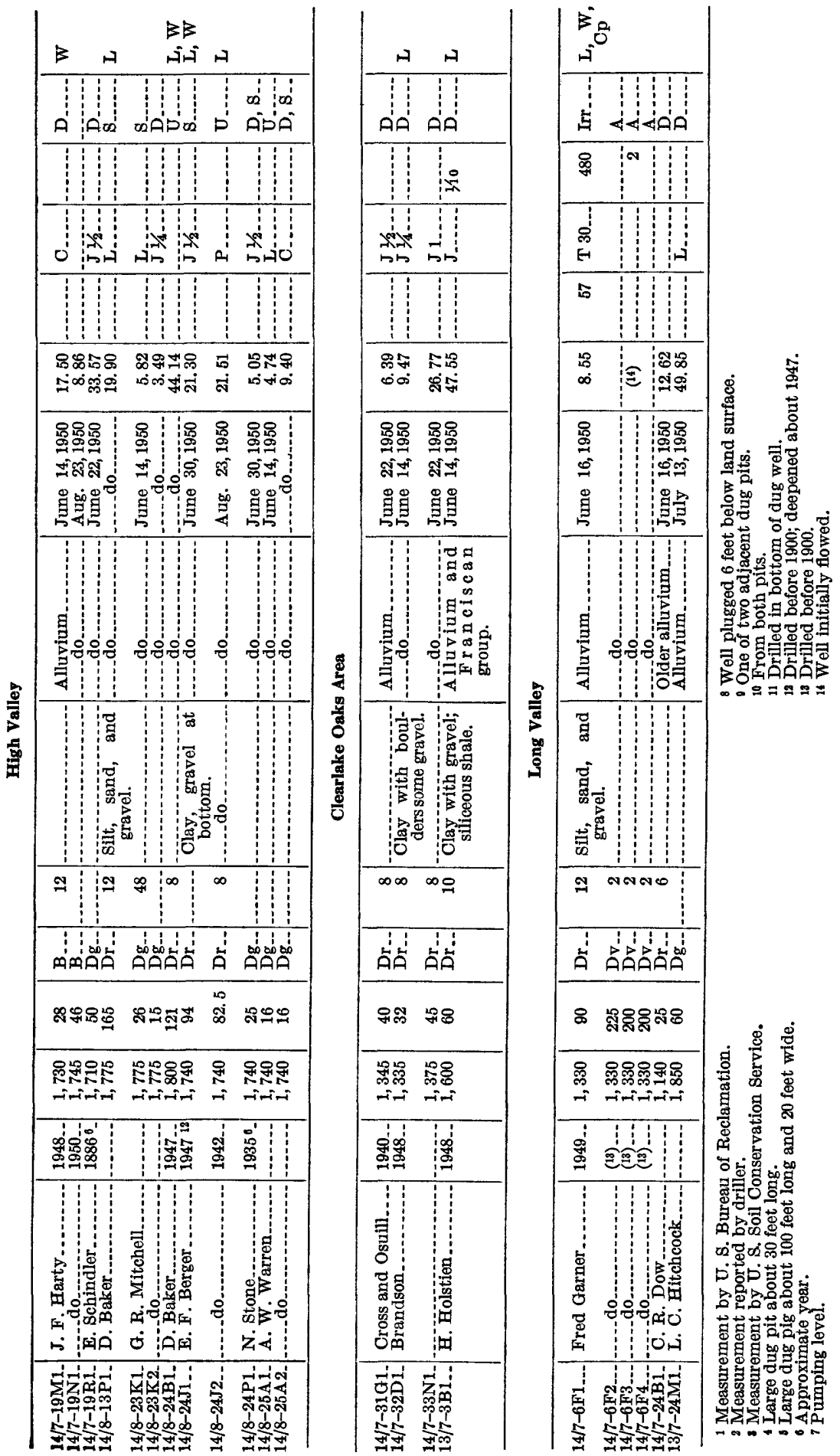


Apparently, the ground water in Long and Collayomi Valleys is not confined or under artesian head. The difference between shallow and deep water levels was not significant in any of the wells that were examined. Wells 10/7-3D1 and 10/7-3D2, about half a mile west of Middletown, were drilled and dug to depths of 170 and 16 feet, respectively. Simultaneous measurements in these wells indicate that the water levels are at the same altitude. Logs of wells are inadequate to reveal the presence of extensive impermeable or confining layers in the alluvium. Also, owners of wells have not reported hardpan, standing water after rains, or other evidence of confining or impermeable layers. Therefore, even though the alluvium of these valleys is fine grained, water that falls on the land surface or flows in the creeks probably can percolate to the ground-water body.

Few data are available on which to base an estimate of the groundwater storage capacity of Collayomi and Long Valleys. However, it is possible to estimate the magnitude of the gross storage capacity of the valley alluvium down to 100 feet. The total area of the alluvium is about 4,400 acres. Within much of this area the alluvium is less than 100 feet thick. However, it is not unreasonable to estimate that the alluvium is at least 100 feet thick within an area of 4,000 acres. Assuming an average depth to water of 10 feet, 90 feet of the alluvium would be saturated. Also, assuming a specific yield of 8 percent, ${ }^{3}$ the amount of ground water in storage would be about 29,000 acre-feet. Because the alluvium is considerably thicker than 100 feet in the central part of the valley, this figure is a minimum estimate of gross storage capacity; there is little information on usable storage capacity.

From the standpoint of its mineral content, all of the water in Collayomi and Long Valleys appears to be suitable for irrigation and domestic purposes. However, residents report that surface or ground water that is in contact with serpentine before use is very hard and unpleasant to the taste. Waring $(1915$, p. 15) indicates that the unpleasant taste is probably caused by magnesium. The following partial chemical analyses of water from representative wells show that the chloride content and hardness are low. The concentration of boron was not determined nor were there sufficient analytical data to compute the percent sodium.

3 Here and elsewhere in the report, estimates of specific yield are based largely on rough comparisons of the lithologies of the deposits with the lithologies and corresponding specific yield values of the Sacramento Valley, as reported by Poland, J. F., Davis, G. H., Olmsted, F. H., and Kunkel, Fred (1951). 
Partial analyses of water from Collayomi Valley, July 13, 1950

\begin{tabular}{|c|c|c|c|c|}
\hline Well & $\underset{\text { (ft) }}{\text { Depth }}$ & $\begin{array}{c}\text { Chloride } \\
(\mathrm{ppm})\end{array}$ & $\underset{(\mathrm{ppm})}{\text { Hardness }}$ & $\begin{array}{c}\text { Specific } \\
\text { conduct- } \\
\text { ance } \\
\text { (micromhos } \\
\text { at } 25^{\circ} \mathrm{C} \text { ) }\end{array}$ \\
\hline $\begin{array}{l}11 / 7-35 \mathrm{E} 12 \\
11 / 7-35 \mathrm{E} 2-1\end{array}$ & $\begin{array}{r}151 \\
10\end{array}$ & $\begin{array}{l}7.3 \\
1.0\end{array}$ & $\begin{array}{l}142 \\
156\end{array}$ & $\begin{array}{l}342 \\
332\end{array}$ \\
\hline
\end{tabular}

\section{POSSIBITTY OF FURTHER DEVELOPMEN'T}

It seems likely that the use of ground water in Collayomi Valley can be expanded considerably. The alluvium in the western part of the valley, which has not been explored by wells, probably contains gravel beds representing old channels of Putah Creek. Possibly, similar gravels may be found near the channel of St. Helena Creek and in the area southwest of Middletown opposite the canyon of Dry Creek. The alluvium northwest of Middletown may be over 200 feet thick, comprising a large reservoir. Of course, the thickness decreases to a feather edge at the margins of the alluvial plain.

The chances of developing very productive wells in Long Valley are small, because most of the alluvium is probably clay and silt. However, by exercising care in the construction and development of new wells (p. 77), the production of ground water, at least in small quantities, can be increased.

The extent to which development of the ground-water bodies can be increased and sustained depends on (1) the rate at which ground water can be withdrawn, (2) the rate it can be replenished, and (3) the total amount of water that reaches the valley each year from the drainage area.

The total amount of water available constitutes the top limit of development. The estimated average precipitation on the 41,000 acres of drainage area tributary to Collayomi and Long Valleys is 36 inches a year, or about 125,000 acre-feet of water. Much of this water is lost to vegetation on the hillsides, and most of the remaining water runs off during storms, having little opportunity to seep into the valley alluvium because the ground-water reservoir is nearly full. Therefore, only a small percent of the water that falls within the drainage area actually replenishes the ground-water body. However; if water levels were lowered by pumping during the summer, more storage space would be available.

The natural discharge of the basin may be an indication of the amount of water available. For any basin, the total inflow must equal the total discharge in a given period, plus or minus the change $323058-55-6$ 
in ground-water storage for that period. Change in storage is difficult to determine, but where there is little or no pumping draft, as in Collayomi and Long Valleys, the change is probably negligible for a short period of time. Therefore, the total amount of water available is about equal to the natural discharge. The natural discharge consists of evapotranspiration and surface runoff from the drainage area. In Collayomi Valley, underflow is negligible. Assuming that the evapotranspiration cannot be salvaged, the surface runoff is a measure of the total amount of water available under natural conditions.

Runoff on Putah Creek near Guenoc at the outlet of Coyote Valley was gaged from January 1904 to July 1906 and has been measured continuously since July 1930 (table 3). The median annual runoff during the water years (Oct. 1 to Sept. 30) 1931-50 was 95,365 acrefeet. The total drainage area above the gage is 106 square miles, of which 64 square miles is the drainage area of Collayomi and Long Valleys, and 42 square miles is the drainage area of Coyote Valley. Prorated in this proportion, the median annual runoff from the drainage area of Collayomi and Long Valleys is about 60,000 acre-feet. For every 1 percent of this amount that would percolate into the ground-water body of Collayomi Valley, the area would sustain an average ground-water draft of 600 acre-feet per year.

The low-water summer runoff affords a minimum value for the available water in a basin. This runoff from Collayomi and Long Valleys was measured at a site on Putah Creek in the NW/1/4 SW $1 / 4$ sec. 26, T. 11 N., R. 7 W. (See pl. 1.) On July 14, 1950, it was 3.7 cfs (cubic feet per second); on August 8, 1950, it was $0.50 \mathrm{cfs}$; and on October 10,1950 , it was only a small trickle. On the same days, the flow of St. Helena Creek into the valleys, measured in the $\mathrm{SE}_{1 / 4}^{1 / \mathrm{SW}^{1 / 4}}$ sec. 14, T. 10 N., R. 7 W., was $0.85 \mathrm{cfs}, 0.38 \mathrm{cfs}$, and $0.56 \mathrm{cfs}$, respectively. At the time of these measurements there was no surface flow in St. Helena Creek near Middletown or in Putah Creek at the bridge on Harbin Springs road in sec. 34. Accordingly, all of the measured flow out of Collayomi and Long Valleys was ground-water discharge. However, the rates obtained are not representative of average conditions, because the measurements were made after several years of subnormal rainfall. Also, some wells were being pumped for irrigation at the time the measurements were made, which may have affected the discharge. Thus the normal low-water discharge would probably average at least $1.5 \mathrm{cfs}$, or 1,100 acre-feet, in the month of lowest flow. The average low flow of all other months is greater than $1.5 \mathrm{cfs}$. Therefore, at least 1,100 acre-feet of water, and possibly several thousand acre-feet, is the minimum amount available for groundwater development each year. This is considerably more than is now being used. 


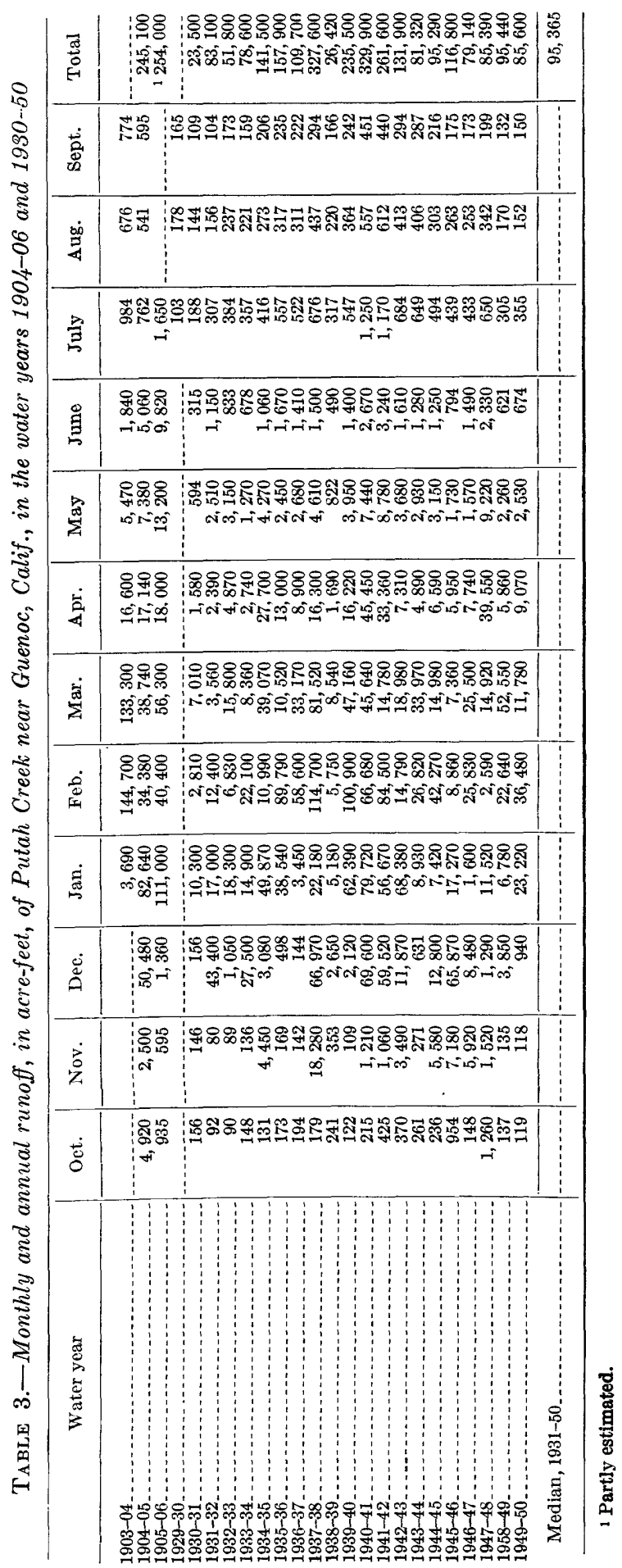




\section{COYOTE VALLEY}

\section{PHYSICAL AND CULTURAL FEATURES}

Coyote Valley (pl. 1) lies about 4 miles northeast of Middletown and is separated from Collayomi and Long Valleys by a ridge composed of Franciscan or Knoxville rocks. Putah Creek cuts through this ridge in a narrow canyon, enters Coyote Valley at its northwest end, and discharges at its eastern end. Coyote Valley, which trends southeast, is irregularly shaped, about 5 miles long, and about $21 / 2$ miles in maximum width. The southeastern part of the valley is nearly isolated by low hills composed of basalt that rise above the alluvial surface. The total drainage area is about 42 square miles, of which the alluvial plain comprises about 6 square miles, or about 4,000 acres.

In 1950 development of ground water in Coyote Valley was limited to about 12 domestic wells and 4 irrigation wells. Some water for irrigation is pumped from Putah Creek. However, the total pumpage has probably never exceeded 400 acre-feet per year, and the groundwater pumpage has probably never exceeded 150 acre-feet per year.

\section{GEOLOGY}

The drainage area of Coyote Valley outside the alluvial plain is underlain by non-water-bearing serpentine, silicified sandstone, and shale of the Franciscan group and Knoxville formation; by non-waterbearing sandstone and shale of Cretaceous age or older; and by voleanics of uncertain age. These consolidated rocks surround the central alluvial plain of the valley except for the two bedrock channels through which Putah Creek flows into and out of the valley from west to east.

Evidence for the physiographic history of Coyote Valley is not available. Probably, Putah Creek has maintained its course through the valley by alluvial filling as the basin subsided, and by excavation of the canyon through the basalt flows bordering the northeastern side of the basin.

As far as is known, the only water-bearing material of Coyote Valley is the alluvium, although volcanic rocks and underlying tuffaceous deposits along the north edge and in the southeastern part of the valley may be water-bearing. The tuffaceous deposits described by Brice (1954) are poorly consolidated and apparently lie at considerable depth beneath the hills to the northeast, where they are overlain by, and perhaps interbedded with, basaltic flows. Similar deposits also crop out along the west base of the hill in sec. $29, T .11 \mathrm{~N}$., R. 6. W. Presumably, these beds underlie the alluvium of Coyote Valley; the basalt perhaps does not. If the tuffs are thick, they might yield water to wells in fairly large quantities. The deepest well in the valley for which a $\log$ is available is $11 / 6-30 \mathrm{~B} 1$, which 
apparently did not pass through the alluvium; it is not known whether or not there are water-bearing beds beneath the alluvium.

The alluvium of Coyote Valley consists of flood-plain and channel deposits of Putah Creek, gently sloping alluvial fan deposits (mostly in the southwestern lobe of the valley, but also near all of the valley margins), and lake or swamp deposits beyond the hills that isolate the southeastern part of the valley.

The alluvial fan deposits and the lake or swamp deposits are composed predominately of fine-grained material. The alluvial fans have low slopes and, like the alluvial fans of Collayomi Valley, only small drainage areas. Also, in the southeastern part of the valley, on the Mary Bowcher ranch, the material at the surface is fine silt and the alluvial plain is nearly flat, suggesting that it was once a swamp or lake bed. Accordingly, the deposits at depth are believed also to be fine grained.

On the other hand, the present channel of Putah Creek contains much coarse gravel. Its flood plain, which appears to cover the entire northwest part of the valley, probably has buried many old stream courses. If so, the yields of wells drilled into the gravels of the stream courses might be comparable to those of the sumps along St. Helena Creek. Wells $11 / 6-19 \mathrm{P} 1$ and $11 / 6-30 \mathrm{~B} 1$ penetrate gravel beds that are presumed to be in old channels of Putah Creek, and each has a reported discharge of about $400 \mathrm{gpm}$. Few wells have been drilled, however, and logs are not available for most of the area.

The thickness of the alluvium in Coyote Valley is unknown. Well 11/6-30B1 was drilled to a depth of 82 feet without reaching bedrock. Assuming that the physiographic history and rate of downwarp are about the same as for Collayomi Valley, an estimated thickness of 200 feet of alluvium appears reasonable.

Logs of wells in Coyote Valley

11/6-30B1, Eric Johnson

[On alluvial plain of Coyote Valley. Reported by foreman]

\begin{tabular}{|c|c|c|}
\hline & $\begin{array}{c}\text { Thickness } \\
\text { (feet) }\end{array}$ & $\underset{\text { (feet) }}{\text { Depth }}$ \\
\hline $\begin{array}{l}\text { Alluvium: } \\
\text { Old dug well. } \\
\text { Clay and gravei (a few feet of each), alternating; bottom in gravel. }\end{array}$ & $\begin{array}{l}22 \\
60\end{array}$ & $\begin{array}{l}22 \\
82\end{array}$ \\
\hline
\end{tabular}

11/6-30B2, Fric Johnson

[On alluvial plain of Coyote Valley. Reported by foreman]

\begin{tabular}{|c|c|c|}
\hline & $\begin{array}{c}\text { Thickness } \\
\text { (feet) }\end{array}$ & $\begin{array}{l}\text { Depth } \\
\text { (feet) }\end{array}$ \\
\hline Alluvium: & \multirow{3}{*}{$\begin{array}{r}20 \\
2 \\
23 \\
10\end{array}$} & \multirow{3}{*}{$\begin{array}{l}20 \\
22 \\
45 \\
55\end{array}$} \\
\hline Gravel. & & \\
\hline Graveì- & & \\
\hline
\end{tabular}




\section{GROUND WATER}

In Coyote Valley, large amounts of ground water occur only in the alluvium, and most of the wells penetrate the alluvium. Static water levels have not been observed at depths greater than 20 feet. However, if the ground water were to be further developed and heavily pumped, the summer levels would drop to greater depths. Periodic water-level measurements in observation wells follow. Miscellaneous data are given in table 2.

11/6-19G1. Roy Tremble. About 0.25 mile north of Putah Creek, about 300 feet east of State Highway 53, 50 feet southeast of dwelling, and 5 feet east of frame tank tower. Measuring point, top of casing east side, 0.9 foot above land-surface datum and about 960 feet above sea level.

Water levels, in feet below land-surface datum, 1949-52

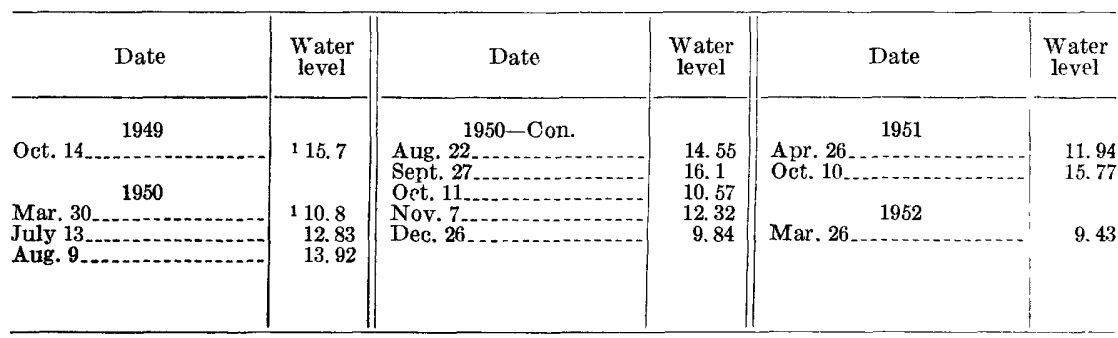

1 Measurement by U. S. Bureau of Reclamation.

11/6-30B1. Eric Johnson. About 0.4 mile east-southeast of State Highway 53 , in walnut orchard 290 feet north of gravel road. Measuring point, top of casing south side, 1.0 foot above land-surface datum and about 960 feet above sea level.

Water levels, in feet below land-surface datum, 1949-52

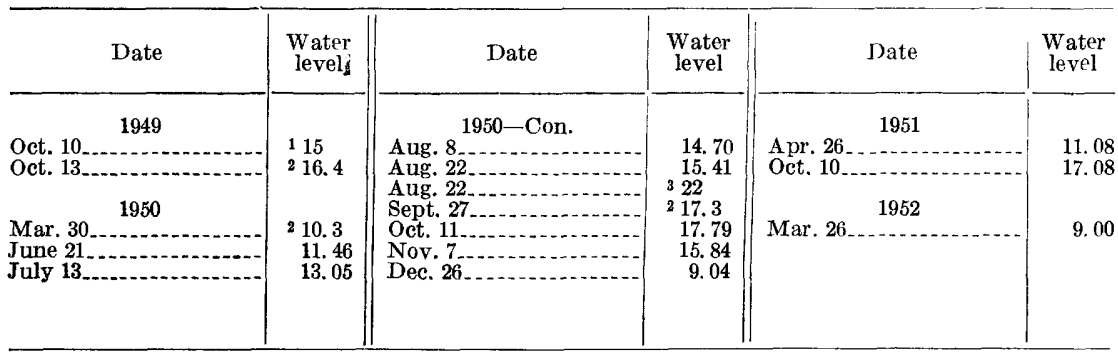

1 Measurement by U. S. Soil Conservation Service.

2 Measurement by U. S. Bureau of Reclamation.

3 Pump operating in well for 5 minutes.

Examination of wells does not indicate confined or artesian water in Coyote Valley. However, the wells may be too few and shallow to have tapped artesian water. If during an earlier period of uplift the outlet of Coyote Valley was higher and held back more water than now, the swamp or basin at the eastern end would have been more extensive and would have received more fine silt and clay than 
now. This material would form an impermeable cover over gravels of Putah Creek that were laid down during earlier stages of deposition. Thus in the eastern part of Coyote Valley, ground water beneath the impermeable cover might be under artesian head. In the western part of the valley the ground water is probably not confined.

Some of the ground water of Coyote Valley is derived from rain that falls on the 42 square miles of drainage area, although most of this water is absorbed by vegetation or carried by the streams as runoff; and some is derived from the outflow from Collayomi and Long Valleys.

The total area of the alluvium in Coyote Valley is about 4,000 acres. Beneath 3,000 acres of this area the alluvium is estimated to be at least 100 feet thick. Assuming that the average depth to water is 10 feet and that the specific yield is 10 percent, the gross ground-water storage capacity of the alluvium is at least 27,000 acre-feet.

From the standpoint of its mineral content, all of the water in Coyote Valley is probably suitable for irrigation and domestic purposes. However, some of the surface water is reported to have an unpleasant taste. The following partial chemical analyses of water from wells and from Putah Creek indicate that the chloride content is low, although the water is moderately hard.

Partial analyses of water from Coyote Valley, 1950

\begin{tabular}{|c|c|c|c|c|c|}
\hline Well or stream & $\begin{array}{l}\text { Depth } \\
\text { (feet) }\end{array}$ & Date sampled & $\begin{array}{c}\text { Chloride } \\
\text { (ppm) }\end{array}$ & $\underset{(p p m)}{\text { Hardness }}$ & $\begin{array}{l}\text { Specific } \\
\text { conductance } \\
\text { (mieromhos } \\
\text { at } 25^{\circ} \mathrm{C} \text { ) }\end{array}$ \\
\hline $\begin{array}{l}11 / 6-20 \mathrm{M} 1 \\
11 / 6-30 \mathrm{~B} 1 \\
11 / 6-30 \mathrm{~B} 2 \\
\text { Putah Creek at Guenoc gage }\end{array}$ & $\begin{array}{r}\text { Sump } \\
82 \\
55\end{array}$ & $\begin{array}{l}\text { Oct. } 12 \\
\text { Aug. } 22 \\
\text { July } 13 \\
\text { Oct. } 10\end{array}$ & $\begin{array}{r}9.4 \\
7.4 \\
9.0 \\
13\end{array}$ & $\begin{array}{l}219 \\
169 \\
190 \\
214\end{array}$ & $\begin{array}{l}444 \\
346 \\
387 \\
438\end{array}$ \\
\hline
\end{tabular}

POSSIBILITY OF FURTHER DEVELOPMENT

The extent to which ground-water development can be increased in Coyote Valley depends, as it does in Collayomi and Long Valleys, on the rate at which ground water withdrawn can be replenished, and on the total amount of water that reaches the valley each year from the drainage area.

On the basis of the runoff record near Guenoc (table 3), the median annual outflow from Coyote Valley is about 95,000 acre-feet. Prorated on an areal basis, about 60,000 acre-feet of the runoff is from Collayomi and Long Valleys. Accordingly, the median annual inflow to Coyote Valley from its own drainage area is about 35,000 acre-feet. 
The median minimum flow of Putah Creek near Guenoc is about 160 acre-feet per month. Because there is no through flow of Putah Creek during the period of low discharge, this figure represents the minimum monthly ground-water discharge for Coyote Valley. For a 12-month period this discharge is about 2,000 acre-feet, which is the amount of water that would be available for use each year, provided it could all be pumped.

If the ground water draft were increased, it is likely that more of the winter runoff would go into storage. Probably enough water would then be available to irrigate much of the alluvial plain, although around the margins and in the southeastern part it might be difficult to obtain wells of adequate yield.

\section{EXCELSIOR AND IITTLE HIGH VALLEYS}

PHYSICAL AND CULTURAL Features

Excelsior Valley (pl. 1), is an irregularly shaped valley which lies from 1 to 2 miles south of the town of Lower Lake. It is drained by Copsey Creek, a small, intermittent tributary to Cache Creek. The valley consists of northern and southern parts, separated by a barrier of consolidated rocks through which Copsey Creek has cut a narrow channel. There are no towns within the drainage area, but State Highway 53, from Middletown to Lower Lake, passes along the western side of the valley. Little High Valley is a small undeveloped tributary basin about 1 mile southeast of the southern part of Excelsior Valley, from which it is separated by consolidated rocks. The total drainage area of both valleys is 10,400 acres, or about 16 square miles. Of this area, the alluvial plain of both parts of Excelsior Valley comprises about 1,400 acres, and that of Little High Valley comprises about 250 acres. Ground-water development is limited to a few domestic wells of low production and one irrigation well, which is reported to pump $100 \mathrm{gpm}$.

\section{GEOLOGY}

The drainage area of Excelsior Valley, except for the alluvial plain and the lava plateaus, is underlain by sandstone and shale, the greater part of which are probably Cretaceous in age. Drilling reports indicate that these consolidated rocks are "dry." Well 12/7-11Q1, drilled to a reported depth of 780 feet, did not penetrate water-bearing zones. The lava plateaus at the southeastern end of the valley and along the western edge of the drainage area are rough and untillable, and, as far as is known, have not been tapped by wells. However, the lavas may absorb considerable precipitation and store it in joints and fissures. In a few places this water discharges as springs from open fractures or at the top of impermeable zones. 
The floor of Little High Valley contains an alluvial fill in a shallow basin in volcanic rocks. Because of the small size of the drainage area, the fill is probably shallow and fine grained. Wells have not been drilled here.

Excelsior Valley is considered to be predominantly erosional in origin. The very irregular pattern of the alluvium seems incompatible with simple warping. Consolidated rock crops out in the creek bed at the road crossing in sec. 14, T. 12 N., R. 7 W., and Brice (1954) maps a thread of shale along the creek channel across the entire northern part of the valley. Thus, the maximum thickness of the alluvium is probably not more than about 25 feet. A number of test wells have been drilled near the outlet of the valley (wells $12 / 7-11 \mathrm{~K} 2$, $-11 Q 1$, and $-11 \mathrm{Q} 2)$. The logs, reported by the owner, indicate a thickness of as much as 80 feet of alluvium in that area, but it is believed that the drillers have misidentified some of the consolidated rock. In much of Excelsior Valley the consolidated rock is a soft shale that can be bored easily with a hand auger. Therefore, the shale is frequently thought to be clay, and drilling is continued to unnecessary depths in the hope of penetrating water-bearing gravel. A comparison of cuttings of this "clay" with the shale exposed in the channel of Copsey Creek would be of help to anyone in doubt. In the southern part of Excelsior Valley, well 12/7-23B1 penetrated shale at a depth of about 45 feet. Because of the constriction between the southern and northern parts of Excelsior Valley, Copsey Creek may have deposited more of its load in the southern part. Nearly all of the wells in Excelsior Valley are near the border of the alluvial plains; the thickness and character of the alluvium in the middle are not well known.

The only water-bearing material of consequence in Excelsior Valley is the aluvium, predominantly a flood-plain deposit. Neither Copsey Creek nor its unnamed tributary from Little High Valley are depositing, or appear to have deposited, fans of large size. The channel gravels of these creeks are only a few feet thick, and except for a few pools along Copsey Creek in the southern part of Excelsior Valley, the streams do not carry water during the summer months. Where observed in creek banks and as reported in well logs, the alluvium is composed of clay or flood-plain silt, clay with gravel, and fine- or medium-grained gravel. Only one irrigation well is known in Excelsior Valley, and the domestic wells have small yields. Most of these wells are less than 50 feet deep and supply only the minimum domestic needs of the small ranches. Therefore, it appiars that ground-water development in Excelsior Valley cannot be much increased. 
Logs of wells in Excelsior Valley

12/7-11K2, Frank Boone

[On alluvial plain near Copsey Creek. Reported by owner]

\begin{tabular}{|c|c|c|}
\hline & $\underset{\text { (feet) }}{\text { Thickness }}$ & $\begin{array}{l}\text { Depth } \\
\text { (feet) }\end{array}$ \\
\hline $\begin{array}{l}\text { Alluvium: } \\
\text { Soil } \\
\text { Gravel } \\
\text { Clay with gravel } \\
\text { Gravel } \\
\text { Shale, soft, blue. }\end{array}$ & $\begin{array}{r}20 \\
6 \\
22 \\
5 \\
1\end{array}$ & $\begin{array}{l}20 \\
26 \\
48 \\
53 \\
54\end{array}$ \\
\hline
\end{tabular}

12/7-11Q1, Frank Boone

[In apple orchard on alluvial plain. Reported by owner]

\begin{tabular}{l|r|r}
\hline & $\begin{array}{r}\text { Thickness } \\
\text { (feet) }\end{array}$ & $\begin{array}{r}\text { Depth } \\
\text { (feet) }\end{array}$ \\
\hline $\begin{array}{c}\text { Alluvium: } \\
\text { Clay and gravel, some water cased off....... }\end{array}$ & 80 \\
Shale and sandstone, no water.... & 80 \\
\hline
\end{tabular}

12/7-11Q2, Frank Boone

[On alluvial plain about 500 feet west of Copsey Creek. Reported by owner]

\begin{tabular}{|c|c|c|}
\hline & $\begin{array}{c}\text { Thickness } \\
\text { (feet) }\end{array}$ & $\begin{array}{l}\text { Depth } \\
\text { (feet) }\end{array}$ \\
\hline $\begin{array}{l}\text { Alluvium: } \\
\text { Soil, clay and gravel }\end{array}$ & $\begin{array}{l}20 \\
37\end{array}$ & $\begin{array}{l}20 \\
57\end{array}$ \\
\hline
\end{tabular}

12/7-11R1, Frank Boone

[On alluvial plain near Copsey Creek, about 500 feet south of 12/7-11K2. Reported by owner]

\begin{tabular}{|c|c|c|}
\hline & $\begin{array}{c}\text { Thickness } \\
\text { (feet) }\end{array}$ & $\begin{array}{l}\text { Depth } \\
\text { (feet) }\end{array}$ \\
\hline 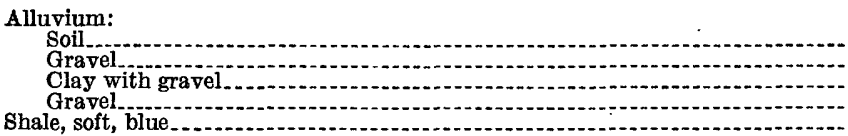 & $\begin{array}{r}19 \\
7 \\
44 \\
9 \\
1\end{array}$ & $\begin{array}{l}19 \\
26 \\
70 \\
79 \\
80\end{array}$ \\
\hline
\end{tabular}

GROUND WATER

Except for a few springs, ground water in Excelsior Valley occurs only in the alluvium. The only water obtained by wells in the consolidated rocks seeps from the overlying soil. As far as is known, wells have not been drilled in the lava plateau southeast of Excelsior Valley. Periodic water-level measurements in two wells in the alluvium of Excelsior Valley follow. Miscellaneous data are given in table 2. 
12/7-14C2. J. A. Smith. About 1.4 miles south of Lower Lake, 0.05 mile west of State Highway 53, 30 feet west of frame dwelling, under frame tank tower. Measuring point, center of U. S. G. S. copper washer on side of 2- by 6-inch support at land surface, and about 1,390 feet above sea level.

Water levels, in feet below land-surface datum, 1949-52

\begin{tabular}{|c|c|c|c|c|c|}
\hline Date & $\begin{array}{l}\text { Water } \\
\text { level }\end{array}$ & Date & $\begin{array}{l}\text { Water } \\
\text { level }\end{array}$ & Date & $\begin{array}{l}\text { Water } \\
\text { level }\end{array}$ \\
\hline 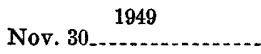 & 117 & Aug. 22 & 16. 22 & Apr. 26_. 1951 & 6.23 \\
\hline \begin{tabular}{l}
\multicolumn{1}{c}{1950} \\
June $15 \ldots$ \\
Aug. 8
\end{tabular} & $\begin{array}{l}13.73 \\
15.81\end{array}$ & $\begin{array}{l}\text { Nov. } 7 \\
\text { Dec. } 26-\end{array}$ & $\begin{array}{r}16.49 \\
8.90\end{array}$ & Mar. 26. 1952 & 2.75 \\
\hline
\end{tabular}

1 Measurement by Soil Conservation Service.

12/7-23B1. Louella Adamson. About 2.5 miles south of Lower Lake, about 0.3 mile south of Adamson Ranch entrance on State Highway 53, 0.25 mile south of Copsey Creek, in open field 115 feet north and 30 feet east of fence corner. Measuring point, hole in north side of pump base, 0.3 foot above land-surface datum, and about 1,410 feet above sea level.

Water levels, in feet below land-surface datum, 1950-52

\begin{tabular}{|c|c|c|c|c|c|}
\hline Date & $\begin{array}{l}\text { Water } \\
\text { level }\end{array}$ & Date & $\begin{array}{l}\text { Water } \\
\text { level }\end{array}$ & Date & $\begin{array}{l}\text { Water } \\
\text { level }\end{array}$ \\
\hline $\begin{array}{l}\text { Apr. } 6 \ldots 50 \\
\text { July } 10 \\
\text { Aug. } 8 \\
\end{array}$ & $\begin{array}{l}2.58 \\
6.15 \\
7.02\end{array}$ & $\begin{array}{l}\text { Oct. } 11.50-\text { Con. } \\
\text { Nov. } 726 \\
\text { Dec. } 26\end{array}$ & $\begin{array}{r}6.80 \\
6.52 \\
.10\end{array}$ & $\begin{array}{l}1951 \\
\text { Apr. 26. } \\
\text { Oct. 10 } \\
\text { Mar. 26. } 1952 \\
\end{array}$ & $\begin{array}{r}1.50 \\
6.30 \\
.18\end{array}$ \\
\hline
\end{tabular}

Evidence that the ground water in Excelsior Valley is confined or under artesian pressure has not been found. Water levels in the southern part of the valley stand about 10 feet below land surface. Apparently, the water levels are somewhat higher here than they are in the northern part, probably because of the bedrock barrier between the two parts.

The ground-water storage capacity of the alluvium in Excelsior Valley is very small. The alluvium is thin, and at places the water table may be only a few feet above the bedrock surface. At some places, where consolidated rock may extend above the water table, the alluvium will not contain water. It is believed that the thickness of saturated material is greater in the southern than in the northern part of the valley.

The only pumpage of consequence is from well $12 / 7-23 \mathrm{~B} 1$, which is reported to sustain a draft of about $110 \mathrm{gpm}$. However, the total quantity of water that has been pumped is very small. 
All of the ground water in Excelsior Valley is derived from precipitation that falls within the drainage area. Water does not reach the valley by underground percolation from other basins or by streams from other drainage areas. Because of the thinness and low permeability of the alluvium, water from the creek cannot readily seep into the ground-water body. Most of the replenishment, therefore, is probably from rainfall on the alluvium and seepage from the adjoining hillsides.

\section{POSSIBILITY OF FURTHER DEVELOPMENT}

A large quantity of water falls on the drainage area of Excelsior Valley. Most of it is absorbed by the soil and transpired by plants; however, the remaining water is more than sufficient to recharge the ground-water body. The storage capacity of the alluvium may be roughly estimated as being between 1,000 and 2,000 acre-feet. However, it would be impossible to pump more than a few hundred acrefeet each year because of the low permeability of the alluvium. In the areas of deepest alluvium, the supply of ground water is probably sufficient to meet moderate domestic needs; bowever, irrigation wells of large yields probably cannot be developed. Wells drilled in the consolidated sandstone and shale, regardless of depth, cannot be expected to yield much water.

Estimates of the amount of water available from the lava plateaus southeast of Excelsior Valley have not been made, but it is likely that wells drilled in structural troughs or depressions might yield enough water for domestic and stock use. The alluvium of Little High Valley is too thin to contain much ground water.

\section{MANNING FLAT}

Manning Flat (pl. 1) is a small alluvial plain about 5 miles west of the town of Lower Lake along the highway to Kelseyville. Its total drainage area covers about 2 square miles, and its alluvial plain, about 200 acres. Until recently Manning Flat was a closed basin containing an intermittent lake. All precipitation on hillslopes that was not lost by transpiration and evaporation accumulated in the central part of the basin and slowly evaporated or was consumed by plants. The Soil Conservation Service at Middletown reports that 50 or 75 years ago a tunnel was dug through the divide to drain the water of Manning Flat into Thurston Lake, another closed basin more than 400 feet lower in altitude. The tunnel later collapsed and is now a gully that is advancing headward into the Flat. Wash from this gully has greatly reduced the size of Thurston Lake.

The slopes along the south side of the narrow part of Manning Flat are underlain by silicic dacite, the western and northwestern 
sides are underlain by obsidian, and the other bordering slopes are underlain by rhyodacite. The alluvial deposit of the flat is composed of fine silt with a maximum thickness of about 20 feet. It is entirely above the water table, and after a rain it is immediately drained by the large gully. Nothing is known about the water-bearing properties of the silicic dacite, but the formation is believed to be not water bearing. Well $12 / 8-1 \mathrm{~K} 1$, drilled to a depth of slightly more than 200 feet in the rhyodacite, was dry on June 22, 1950. However, the obsidian probably is water bearing, because in other areas wells that penetrate it yield large quantities of water.

It is unlikely that ground water can be developed from the alluvium or the silicic dacite. However, the rhyodacite might contain water; if so, its zone of saturation is deeper than any wells in the flat that have been drilled.

\section{BONFIELD, HESSE, AND ELY FLATS}

\section{PHYSICAL AND CULTURAL FEATURES}

Bonfield, Hesse, and Ely Flats (pl. 1), west of Manning Flat, are a series of shallow basins along the channel of Thurston Creek, which flows into Thurston Lake. The total drainage area is about 12 square miles. Numerous dry holes and two successful irrigation wells have been drilled in parts of these areas.

\section{GEOLOGY AND GROUND WATER}

Bonfield, Hesse, and Ely Flats are underlain by alluvial deposits as much as 20 feet thick. In most places the alluvial deposits are probably poorly sorted or are fine grained. Except for well 13/8-33J1, at the lower end of Hesse Flat, wells that penetrate the alluvium have small yields. Well $13 / 8-33 \mathrm{~J} 1$ has a yield reported to be about $400 \mathrm{gpm}$. It consists of 2 pits, which are 12 feet deep, about 25 feet apart, and which are connected to 1 pumping plant. Examination of the material from the pits indicates that here the alluvium is composed of coarse sand, gravel, and boulders of ash and obsidian. The alluvium of other parts of these flats is probably too thin and fine grained to yield even enough water for most domestic needs. Additional water must be obtained from the underlying formations.

The alluvial fill and the surrounding drainage areas of Bonfield, Hesse, and Ely Flats are underlain by the same formations that surround Manning Flat. Bonfield Flat, the southernmost of the three, is in an area underlain predominantly by rhyolitic obsidian, but it is bordered on the south by a body of silicic dacite. Hesse Flat is underlain by rhyolitic obsidian, and Ely Flat is in the area. of rhyodacite. 
Obsidian is the only one of these formations that yields water in appreciable quantities. The manager of the Amber Knoll Orchard reports that well $12 / 8-3 \mathrm{~B} 1$ was drilled in fractured obsidian (locally called bottle rock), but that it bottomed in a hard gray rock that was not obsidian. The well is reported to yield between 600 and $1,000 \mathrm{gpm}$. It was originally 162 feet deep, hence the obsidian is probably at least 160 feet thick at that place. Evidently, the rock is sufficiently fractured to store considerable water, but the extent of the reservoir is not known.

Yields from wells in Ely Flat, which is surrounded by hills underlain by rhyodacite, are insufficient, even for domestic supply. Well 13/8-27P1, 38.5 feet deep, has no pump, although it contains water. Well 13/8-27P2, reported to be shallow, is dry during the summer. Evidently, these wells tap perched water in the surface zone of soil and weathered rock. Wells $13 / 8-34 \mathrm{~B} 1$, and $13 / 8-27 \mathrm{P} 3$, which are 100 and 187 feet deep, respectively pass through the thin alluvium of Thurston Creek and penetrate the rhyodacite. On June 22, 1950, these wells were dry, indicating that there was little seepage into them from the shallow perched water, and that the regional water table in the rhyodacite is deeper than 187 feet. In the zone of saturation, the rhyodacite might be a good water bearer.

There is no information about the water-bearing properties of the silicic dacite along the south side of Bonfield Flat. However, wells drilled in the western part of the flat might yield water from the obsidian, depending on its permeability and thickness and on the position of the water table. If wells of adequate capacity were developed, the possibility of sustaining a good yield would depend on the size of the water body that was tapped and the opportunities for replenishment. However, this information is not available.

Ground water occurs in the alluvium of all three basins, in the obsidian bordering Bonfield and Hesse Flats, and presumably in rhyodacite at considerable depth. In most wells the water stands 10 to 20 feet below the surface; as far as known, the water is not confined. Wells in the rhyodacite around Ely Flat evidently were not deep enough to reach the regional water body, which may slope steeply northward toward Clear Lake. The relationship between ground water in the obsidian and in the underlying formations is not known. The water table in the obsidian appears to be relatively shallow; however, it may be perched on underlying impermeable material. Following are periodic water-level measurements in a 39.5-foot well drilled on the alluvial flat in the area underlain by rhyolitic obsidian. Miscellaneous data are given in table 2. 
13/8-34Q1. Hesse Flat. About 7 miles west of Lower Lake, along highway to Kelseyville. About 0.52 mile east of road to Konocti Bay, 50 feet east of gravel road to Amber Knolls Orchard, in open field, 25 feet north of the center line of Lower Lake-Kelseyville highway. Measuring point, top of casing, 1.1 feet above land-surface datum, and about 1,875 feet above sea level.

Water levels, in feet below or above (+) land-surface datum, 1950-52

\begin{tabular}{|c|c|c|c|c|c|}
\hline Date & $\begin{array}{l}\text { Water } \\
\text { level }\end{array}$ & Date & $\begin{array}{c}\text { Water } \\
\text { level }\end{array}$ & Date & $\begin{array}{l}\text { Water } \\
\text { level }\end{array}$ \\
\hline $\begin{array}{l}\text { Apr. } 7.1950 \\
\text { May } 180 \\
\text { June } 15 \\
\text { July } 11 \\
\end{array}$ & $\begin{array}{l}11.31 \\
12.49 \\
14.29 \\
15.24\end{array}$ & $\begin{array}{l}\text { Aug. } 1950-\text { Con. } \\
\text { Oct. } 11 . \\
\text { Nov. } 7 \\
\text { Dec. } 26\end{array}$ & $\begin{array}{r}17.39 \\
19.42 \\
18.80 \\
9.21\end{array}$ & $\begin{array}{l}\text { Apr. } 26 \ldots 51 \\
\text { Oct. } 10 \\
\text { Mar 26 } 1952 \\
\end{array}$ & $\begin{array}{r}2.35 \\
10.17 \\
+1.1\end{array}$ \\
\hline
\end{tabular}

The source of water in the flats is the precipitation that falls within the drainage area. Presumably, the water discharges toward Clear Lake. An estimate of the quantity and utility of available water was not possible because of insufficient data on the depth, extent, and specific yield of the water-bearing formations. However, the storage capacity is known to be small.

\section{POSSIBIITYY OF FURTHER DEVELOPMENT}

The possibility of future ground-water development in Bonfield, Hesse, and Ely Flats cannot now be evaluated. Much of the land is rough, brush covered, and not suitable for agriculture. However, if water were available, walnuts and perhaps other crops could be grown at a profit in some localities. Therefore, the geologic and hydrologic features of these areas warrant further investigation. Detailed mapping of the extent of the rhyolitic obsidian and its structural relationship to other formations may reveal the existence of a small, but productive, water body; and it might indicate that ground water can be developed in the area east of Ely Flat if deeper wells are drilled.

\section{LOWER LAKE AREA}

\section{PHYSICAT AND CULTURAL FEATURES}

The Lower Lake area (pl. 1) is the lowland at the southeast end of Clear Lake. It includes the alluvial plains of Cache, Herndon, and Seigler Canyon Creeks, the reclaimed land and adjoining narrow alluvial plain surrounding the southeastern tip of the lake, and the terraced area immediately north of the town of Lower Lake. There are numerous domestic wells in the area, several irrigation wells, and the municipal wells that supply the town of Lower Lake. Also, some lake water is pumped for both domestic and irrigation use. 


\section{GEOLOGY}

The principal water-bearing formations in the Lower Lake area are the alluvium and the Cache formation of Anderson. The hills south of Lower Lake are underlain by Cretaceous and Tertiary sedimentary rocks. These older formations are largely not water bearing and were not studied in detail. Wells in these formations are dry, or they yield only a minimum domestic supply. The slopes bordering the reclaimed land on the south are underlain by basalt of Pleistocene age. Nothing is known about the water-bearing character of the basalt.

Davis (1933, p. 197-200) discussed the physiographic history of Clear Lake, ascribing its formation to the damming of eastwardflowing drainage by the rbyodacite and subsequent damming of westward-flowing drainage by landslides. Anderson (1936, p. 662663) supports this hypothesis, but Brice (1954) does not wholly agree with it. Further information was not obtained during this investigation. Cache Creek, flowing eastward on a very low gradient, drains the lake. The lake has been sounded, and nowhere is its depth reported to be greater than about 45 feet. As of March 1944, the lake surface was at an altitude of 1,326 feet, only about 25 feet above the base of the Clear Lake Water Company dam about $2 \frac{1}{2}$ miles. northeast of Lower Lake.

The alluvium is probably thin, and apparently was deposited during relatively recent stages of Clear Lake and not in valleys of the preexisting drainage. If the valley of Herndon Creek formerly drained westward, which is suggested by its alignment, its prealluvial floor could not be much below the level of the bottom of Clear Lake. If the valley of Herndon Creek drained eastward into Cache Creek, the base of the alluvium would be slightly above the bottom of the gorge below the Clear Lake Water Company dam. The altitude of the present surface of the alluvium is about 1,350 feet. Hence, regardless of the direction of drainage, the alluvium is probably not more than 50 to 75 feet in maximum thickness. At most places it probably is less. Unfortunately, logs are not available for wells. that pass through the alluvium.

Few wells have been drilled in the alluvium northwest of Lower Lake, and all of the known wells are less than 50 feet deep. The land has been reclaimed or is a low, flat lake plain. Althougb logsare not available for these wells, it is known that the alluvium was. deposited on the former floor of Clear Lake under quiet conditions, and that it probably consists of clay, silt, and sand, with some gravel 
and perhaps some marl. Irrigation wells $12 / 7-3 \mathrm{M} 1$ and $-3 \mathrm{M} 2$ are on the lake plain. Well $12 / 7-4 \mathrm{~F} 1$ is at the edge of the lake plain, but probably derives much of its water from the alluvium. Although less than 50 feet deep, these wells yield between 400 and $600 \mathrm{gpm}$ with only a few feet of drawdown.

Numerous wells have been drilled along the lakeshore for the resorts north and south of Clearlake Highlands. All were reported to yield sufficient water to satisfy the demands, but the water is unpleasant to drink because of a soda taste. Lake water, with a strong odor of algae, is used in preference to the ground water.

The 3 municipal wells for the town of Lower Lake are on the alluvial plain of Herndon Creek about 1 mile east of the town. Logs are not available for these wells, but the alluvium is probably composed of clay, clay and gravel, and some interbedded gravel. Only one of the municipal wells is pumped at a time. Well $12 / 7-1 \mathrm{M} 2$, originally 55 feet deep, did not yield enough water during the summer of 1950 , and was deepened to 72.5 feet. Mr. Star, superintendent of the water department, reports that this well yields $250 \mathrm{gpm}$ with a drawdown of about 40 feet and a pumping level of 53 feet.

Moderate yields are obtained from the Cache formation. Wells $12 / 7-3 J_{1}$ and $12 / 7-2 \mathrm{M} 1$, drilled in the synclinal trough of the Cache formation near the town of Lower Lake (see p. 54), each yield a minimum of $150 \mathrm{gpm}$. Well $12 / 7-2 \mathrm{M} 1$ is drilled through gravel, limestone, and clay, and bottoms in a "volcanic" gravel which yields water freely. This well has not been tested, but may yield several hundred gpm. The discharge of well 12/7-3J1, 185 feet deep, was estimated at $165 \mathrm{gpm}$. The owner, Mr. Gaines, reports that in irrigating 10 acres of permanent pasture this well has been pumped at the rate of $240 \mathrm{gpm}$. According to the log, the well penetrates nothing but clay below 34 feet. If this well will yield 240 gpm, it seems likely that the clay contains some beds of sand or gravel. Judging from well 12/7-2M1, which penetrates gravel beneath a thick section of clay, well $12 / 7-3 \mathrm{~J} 1$, if deepened, might also penetrate permeable beds beneath the clay and have a greater yield.

Well 12/7-2P1, drilled to a depth of 126 feet, yields a sufficient supply of water for domestic needs. However, it was reported that 75 feet to the southwest a well now destroyed was drilled to a depth of 240 feet and was "dry". The log of well 12/7-2P1 suggests that this well was drilled in the Cache formation, whereas the "dry hole" may have been drilled in the Cretaceous rocks. 


\title{
Logs of wells near Lower Lake
}

\author{
12/7-2P1, Mr. Star
}

[From records of U. S. Soil Conservation Service. Cased from surface to 126 feet, perforated from surface to 60 feet and from 116 to 126 feet]

\begin{tabular}{|c|c|c|}
\hline & $\begin{array}{c}\text { Thickness } \\
\text { (feet) }\end{array}$ & $\begin{array}{c}\text { Depth } \\
\text { (feet) }\end{array}$ \\
\hline $\begin{array}{l}\text { Soil } \\
\text { Cache formation: }\end{array}$ & 5 & 5 \\
\hline $\begin{array}{l}\text { Clay, red and blue } \\
\text { Clay and gravel, mixed. } \\
\text { Clay, blue } \\
\text { Sand and clay } \\
\text { Sand, white. }\end{array}$ & \begin{tabular}{r|r}
55 & 3 \\
27 & \\
10 & \\
26 &
\end{tabular} & $\begin{array}{r}60 \\
63 \\
90 \\
100 \\
126\end{array}$ \\
\hline
\end{tabular}

\section{2/7-2M1, H. Henderlin}

[In Lower Lake. Reported by owner. Cased from surface to 115 feet, perforated from 85 to 115 feet]

\begin{tabular}{|c|c|c|}
\hline & $\underset{\text { (feet) }}{\text { Thickness }}$ & $\begin{array}{l}\text { Depth } \\
\text { (feet) }\end{array}$ \\
\hline Soil Cache formation: & \multirow{5}{*}{$\begin{array}{r}18 \\
2 \\
17 \\
5 \\
65 \\
8\end{array}$} & 18 \\
\hline Gravel & & 20 \\
\hline $\begin{array}{l}\text { Clay, hard, brown } \\
\text { Limestone }\end{array}$ & & $\begin{array}{l}37 \\
42\end{array}$ \\
\hline Olay, blue & & 107 \\
\hline Gravel, “volcanic”' & & 115 \\
\hline
\end{tabular}

12/7-3J1, C. Gaines

[A quarter of a mile northwest of Lower Lake. Reported by owner]

\begin{tabular}{|c|c|c|}
\hline & $\begin{array}{c}\text { Thickness } \\
\text { (feet) }\end{array}$ & $\begin{array}{l}\text { Depth } \\
\text { (feet) }\end{array}$ \\
\hline $\begin{array}{l}\text { Soil } \\
\text { Cache formation: }\end{array}$ & 34 & 34 \\
\hline $\begin{array}{l}\text { Gravel. } \\
\text { Clay }\end{array}$ & $\begin{array}{r}3 \\
148\end{array}$ & $\begin{array}{r}37 \\
185\end{array}$ \\
\hline
\end{tabular}

\section{GROUND WATER}

Ground water in the vicinity of Lower Lake occurs chiefly in the alluvium and the Cache formation of Anderson. Midsummer measurements of depths to water in wells in these formations range between 12 and 25 feet. Periodic water-level measurements in observation wells are given below. Miscellaneous data are given in table 2.

12/7-1M1. Town of Lower Lake. Municipal standby well. About 0.75 mile northeast of Lower Lake, 0.15 mile west of gravel access road on alluvial plain, 0.13 mile north of $90^{\circ}$ turn on dirt access road to dairy, 25 feet west of center line of dirt road, 10 feet east of well 12/7-1M2, 40 feet south of well 12/71M3. Measuring point, top of casing north side, 0.5 foot above land-surface datum, and about 1,330 feet above sea level. 
Water levels, in feet below land-surface datum, 1950-52

\begin{tabular}{|c|c|c|c|c|c|}
\hline Date & $\begin{array}{c}\text { Water } \\
\text { level }\end{array}$ & Date & $\begin{array}{l}\text { Water } \\
\text { level }\end{array}$ & Date & $\begin{array}{l}\text { Water } \\
\text { level }\end{array}$ \\
\hline Oct. 5 & \multirow{3}{*}{$\begin{array}{l}118 \\
217.80 \\
219.36\end{array}$} & $\begin{array}{c}1950-\text { Con. } \\
\text { Aug. } 8\end{array}$ & \multirow{3}{*}{$\begin{array}{r}16.18 \\
14.61 \\
\text { 218. } 53 \\
17.41 \\
12.46\end{array}$} & Apr. 27. 1951 & \multirow{3}{*}{$\begin{array}{r}10.70 \\
216.43 \\
7.34\end{array}$} \\
\hline June 15 & & $\begin{array}{l}\text { Oct. } 11 \\
\text { Nov. } 7\end{array}$ & & 1952 & \\
\hline July 12 & & Dec. 26 & & Mar. 26........ & \\
\hline
\end{tabular}

1 Measurement by U. S. Soil Conservation Service.

2 Pump operating in well 12/7-1M2.

12/7-3J1. C. Gaines. About 0.6 mile west of northwest corner of Lower Lake, 160 feet north of center line of gravel road to Gaines' dwelling, 20 feet west of section-line fence, in frame pump house on concrete slab. Measuring point, top of casing north side, 0.4 foot above land-surface datum, and about 1,375 feet above sea level.

Water levels, in feet below land-surface datum, 1950-52

\begin{tabular}{|c|c|c|c|c|c|}
\hline Date & $\begin{array}{l}\text { Water } \\
\text { level }\end{array}$ & Date & $\begin{array}{l}\text { Water } \\
\text { level }\end{array}$ & Date & $\begin{array}{l}\text { Water } \\
\text { level }\end{array}$ \\
\hline 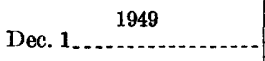 & 120.5 & $\begin{array}{c}1950-\text { Con. } \\
\text { Aug. } 22\end{array}$ & 22. 35 & Apr. 27 1951 & 13. 14 \\
\hline $\begin{array}{l}\text { June } 15 \\
\text { Jug. } 8 \\
\text { Aug }\end{array}$ & $\begin{array}{r}217.64 \\
20.69\end{array}$ & $\begin{array}{l}\text { Nov. } 7 \\
\text { Dec. } 26 .\end{array}$ & $\begin{array}{l}19.74 \\
14.57\end{array}$ & Mar. 26 & 11.06 \\
\hline
\end{tabular}

1 Measurement by U. S. Soil Conservation Service.

Pump operating in well.

13/7-28R1. Millers' Lighthouse Resort. In Clearlake Highlands. About 250 feet east of Clear Lake, 35 feet south of the center line of Millers' road to beach. Measuring point, top of casing west side, 0.5 foot above land-surface datum, and about 1,330 feet above sea level.

Water levels, in feet below land-surface datum, 1950-52

\begin{tabular}{|c|c|c|c|c|c|}
\hline Date & $\begin{array}{l}\text { Water } \\
\text { level }\end{array}$ & Date & $\begin{array}{c}\text { Water } \\
\text { level }\end{array}$ & Date & $\begin{array}{l}\text { Water } \\
\text { level }\end{array}$ \\
\hline $\begin{array}{l}\text { July } 12 \\
\text { Aug. } 950 \\
\text { Oct. } 11 \\
\text { Nov. } 7\end{array}$ & $\begin{array}{r}8.03 \\
9.96 \\
10.32 \\
10.27\end{array}$ & $\begin{array}{c}1950-\text { Con. } \\
\text { Dec. } 26.1951 \\
\text { Apr. } 27 . .\end{array}$ & $\begin{array}{l}6.48 \\
3.72\end{array}$ & 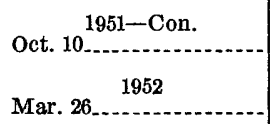 & $\begin{array}{l}8.64 \\
\text { 2. } 77\end{array}$ \\
\hline
\end{tabular}

It appears that the ground water in the alluvium is not confined or under artesian pressure. But the ground water in the Cache formation. of Anderson west of Lower Lake does appear to be under an artesian head. Mr. H. Henderlin reports that during the drilling of his well 12/7-2M1, water under artesian head was tapped between 107 and 115 feet. During very wet weather this well is reported to flow, 
whereas nearby shallow wells do not. The extent of the confined water in the Cache formation is not known, but if well 12/7-3J1 bad been drilled through the clay (p. 54), gravel that yielded water under an artesian bead might have been penetrated.

The water in the Cache formation is probably derived largely from the infiltration of rain that falls on the outcrop area. That in the alluvium is derived partly from infiltration of rain and partly from seepage from Herndon Creek and Clear Lake. The lake has an extensive drainage area, and it would seem that ample water is available from that source. In part, at least, the beds of the Cache formation are in hydraulic continuity with the alluvium; and if draft from the Cache formation were greater than replenishment directly to the formation, the deficiency probably could be made up by percolation from the alluvium, fed in turn by Clear Lake.

The alluvium is probably thin and does not store more than 3,000 to 4,000 acre-feet of water at the most. The alluvium overlies the Cache formation in about two-thirds of the area, and considerable additional storage space is available in that formation. However, its thickness and specific yield in this area are unknown, and an estimate of overall storage capacity, gross or usable, has not been made.

The quality of water in the Lower Lake area merits considerable investigation. Most of the wells drilled in the alluvium adjacent to the lake or on reclaimed land have a strong soda taste. This taste is so unpleasant that the resorts along the shore of Clear Lake use the lake water, with a strong odor of algae, in preference to ground water. Partial analyses of water from well 12/7-1M2, which probably penetrates the Cache formation, and from well $12 / 7-3 \mathrm{M} 1$, which taps the alluvium, indicate that the water is low in chloride content and that it is hard or very hard. The percent of sodium is not known.

Partial analyses of water near Lower Lake, 1950

\begin{tabular}{|c|c|c|c|c|c|}
\hline Source & $\begin{array}{c}\text { Depth } \\
\text { (feet) }\end{array}$ & Date sampled & $\underset{(\mathrm{ppm})}{\text { Chloride }}$ & $\underset{(\mathrm{ppm})}{\text { Hardness }}$ & $\begin{array}{l}\text { Specific } \\
\text { conductance } \\
\text { (micromhos } \\
\text { at } 25^{\circ} \mathrm{C} \text { ) }\end{array}$ \\
\hline $\begin{array}{l}\text { 12/7-1M2 } \\
\text { Clear Lake at McFarland's resort }\end{array}$ & $\begin{array}{l}72 \\
25\end{array}$ & $\begin{array}{l}\text { Oct. 11 } \\
\text { June 15 } \\
\text { Aug. 23. }\end{array}$ & $\begin{array}{l}15 \\
11 \\
11\end{array}$ & $\begin{array}{l}180 \\
237 \\
174\end{array}$ & $\begin{array}{l}447 \\
662 \\
370\end{array}$ \\
\hline
\end{tabular}

Boron, a tasteless element, is present in the lake water near Cache Creek. In small quantities it is harmless to humans and animals, but concentrations greater than $1 \mathrm{ppm}$ are toxic to many plants, and concentrations greater than $3 \mathrm{ppm}$ are toxic to most plants. Walnuts are particularly sensitive to boron poisoning. Table 4 gives the re- 
sults of boron tests that were made by the Rubidoux Laboratory of the U. S. Department of Agriculture for the water of Cache Creek at Clear Lake. Presumably, the samples were taken near the outlet of Clear Lake and represent lake water. They were taken periodically from January 1939 to October 1941.

TABLE 4.-Chemical analyses of water from Cache Creek at Clear Lake, California

[Analyses reported by L. V. Wilcox]

\begin{tabular}{|c|c|c|c|c|c|}
\hline Laboratory no. & Date & $\begin{array}{l}\text { Boron } \\
\text { (ppm) }\end{array}$ & Laboratory no. & Date & $\begin{array}{l}\text { Boron } \\
\text { (ppm) }\end{array}$ \\
\hline & 1939 & & & 1940-Con. & \\
\hline 12571 . & Jan. 20 & 2.28 & 14254 & June 30 & 1.09 \\
\hline 12603. & Feb. 18 & 2.31 & $14717 \ldots$ & July 31 & 1.11 \\
\hline $12676 \ldots$ & Mar. $19 \ldots$ & 1.73 & 14720 & Aug. 31 & 1.13 \\
\hline 12796 & Apr. 21.. & 1.15 & 15651 & Sept. 30 . & 1.24 \\
\hline $12873 .-$ & May 13 & 1.21 & $15653 .$. & Oct. $31 \ldots$ & 1.26 \\
\hline $12960 \ldots$ & June $14 \ldots$ & 1. 29 & & 10041 & \\
\hline $13080 \ldots \ldots$ & $\begin{array}{l}\text { July } 7 \\
\text { Aug. } 2\end{array}$ & $\begin{array}{l}1.28 \\
1.52\end{array}$ & 15936 & Feb_ 1941 & 1.00 \\
\hline $13379 \ldots$ & Sept. 16 & 1.75 & $15937 \ldots$ & Mar..... & .92 \\
\hline 13460. & Oct. 8 & 1.55 & $15938 \ldots$ & Apr & .82 \\
\hline $13544 \ldots$ & Nov. 15 & 1.76 & $15939 \ldots$ & May & .80 \\
\hline & 1940 & & 16329 & July...- & .74 \\
\hline 14176 . & Mar. 31 & 1.30 & $10426 .-$ & Sept..... & .76 \\
\hline 14179 & $\begin{array}{l}\text { Apr, } 30 \\
\text { May } 31 \ldots \ldots\end{array}$ & $\begin{array}{l}1.19 \\
1.20\end{array}$ & 16919 & Oct.... & .95 \\
\hline
\end{tabular}

11941 samples are monthly composites.

The boron concentration was highest in January and February 1939' and lowest in July 1941. Although the source and variation of boron concentration are not fully known, it seems possible that the low concentration in 1941 was due to dilution of the contaminated water by fresh rain and stream water during the wet winter of that year. The source of the boron is presumably related to the volcanics of late Cenozoic age that occur at many places around the lake. Boron is known to be present at Borax Lake, northwest of Clearlake Highlands.

\section{POSSTBILITY OF FURTHER DEVELOPMENT}

It is likely that considerably more water can be developed in the Lower Lake area, but the amount that can be used will depend on the chemical quality. Any well drilled in the alluvium would probably tap ground water in sufficient quantity for domestic needs and local irrigation. At some places, however, the water may be unsatisfactory for domestic use because of unpleasant taste. Also, it is possible that water containing an excessive concentration of boron may be obtained. Wells near the lakeshore may draw water with a high boron content from the lake or from other sources as yet not identified. 
The extent, sources of replenishment, and yield of the ground water in the Cache formation are not entirely known. Additional study of this formation is warranted in connection with future development, because untapped supplies of ground water may be present in the area north of Lower Lake and east of Clearlake Highlands.

\section{BURNS VALLEY}

PHYSICAL AND CULTURAL FEATURES

Burns Valley (pl. 1) is a narrow elongate valley traversed by intermittent unnamed creeks that flow southwestward, entering Clear Lake between Clearlake Highlands and Clearlake Park. The tributary drainage area comprises about $12 \frac{1}{2}$ square miles, or 8,000 acres, about 1,000 acres of which is covered by alluvium. State Highway 53 from Clearlake Highlands crosses the eastern end of this valley and continues north to join State Highway 20. The development of ground water is limited to many shallow domestic wells and three irrigation wells that are less than 200 feet deep. Lake water, pumped by the Highlands Water Co., supplies almost all of the water used by the resorts along the lakeshore at the mouth of the valley and for some distance on either side.

\section{GEOLOGY}

The drainage area of Burns Valley is underlain by the Franciscan group, the Cache formation, and some basaltic rocks. The Franciscan group underlies a large area northwest of the alluvial plain and is in fault contact with the Cache formation of Anderson, which underlies the remainder of the drainage area to the east and south. The Cache formation underlies a terraced terrane bordering part of the alluvial plain and the high hills to the southeast. In a large area around Quackenbush Mountain and in a few localities across: the valley to the north, the Cache formation is overlain by basalt. The only other rock observed in the drainage area of Burns Valley is a small body of rhyolitic obsidian southeast of Borax Lake.

On either side of the upper part of the alluvial plain are remnants. of terraces along at least two levels. These terraces may represent. an older alluvial filling of Burns Valley. However, it is considered more likely that the terraces are erosional in origin, that they cut across the Cache formation, and that they represent a graded condition of the streams at some time before the formation of Clear Lake. Accordingly, these beds are mapped with the Cache formation of Anderson on plate 1. The alluvial fill was formed by subsequent 
downcutting and later backfilling by streams graded to the lake. The complete physiographic history is somewhat more complicated.

The alluvium occupies the lowland and is composed of the gravel channels and flood plains of several unnamed creeks. At most places the alluvium rests on the Cache formation, but locally, in the northern part of the valley near the lake, it lies on or against the older rocks.

The alluvium and the Cache formation are the principal waterbearing deposits of Burns Valley. Logs of wells drilled through the alluvium into the Cache formation are not sufficiently detailed to determine accurately the differences between the formations. However, a few logs (p. 60) and the outcrops of the formations indicate that the alluvium is composed of silt, sand, silt and gravel, and locally clean gravel. The maximum thickness of the alluvium at the lower end of the valley is probably not greater than about 50 feet and it thins to a feather edge at the upper end of the valley.

Well logs and surface outcrops that were examined indicate that much of the Cache formation in Burns Valley is composed of material similar to the alluvium, but more cemented and indurated. It also contains some clean sand and, locally, some interbedded tuff. Limestone has not been reported in well logs, but thin beds of limestone, sand, and marl crop out in the western part of the area. The thickness of the Cache formation in Burns Valley is unknown.

Thus, the alluvium contains material that is sufficiently loose and coarse grained (although it probably contains little coarse gravel) to yield water in moderate quantities. However, its saturated thickness is not great, and a well intended for irrigation would probably be more successful if drilled into the underlying Cache formation. The Cache formation contains water-bearing beds, but it is somewhat more indurated than the alluvium and locally contains considerable clay, as shown by logs of wells 13/7-14E2 and 13/7-15Q1 (p. 60). Therefore, small to moderate yields can be obtained from most wells in the Cache formation, but some wells would probably have poor yields.

A small body of olivine dacite overlain by a rhyolite-obsidian flow is probably not sufficiently permeable to yeild water readily. Well $13 / 7-16 \mathrm{~N} 1$, which was dug in fragmental obsidian, is 61.5 feet deep. On June 16, 1950, the water level in this well was 60.51 feet below land surface, and at that time the well would not have yielded sufficient water for domestic needs. Other data on wells that penetrate these formations are not available. 


\section{Logs of wells in Burns Valley}

13/7-14E2, F. Brun

[On alluvial plain, 250 feet east of creek. Reported by driller]

\begin{tabular}{l|r|r}
\hline & $\begin{array}{r}\text { Thickness } \\
\text { (feet) }\end{array}$ & $\begin{array}{c}\text { Depth } \\
\text { (feet) }\end{array}$ \\
\hline $\begin{array}{c}\text { Alluvium: } \\
\text { Silt with gravel. }\end{array}$ & 12 & 12 \\
Cache formation: \\
Clay, hard, blue, with some sand and gravel, no water
\end{tabular}

13/7-15Q1, F. Bartrum

[On alluvial plain. Reported by G. Bartrum]

\begin{tabular}{|c|c|c|}
\hline & $\begin{array}{l}\text { Thickness } \\
\text { (feet) }\end{array}$ & $\begin{array}{l}\text { Depth } \\
\text { (feet) }\end{array}$ \\
\hline $\begin{array}{l}\text { Alluvium: } \\
\text { Surface material } \\
\text { Gravel }\end{array}$ & $\begin{array}{l}15 \\
25\end{array}$ & $\begin{array}{l}15 \\
40\end{array}$ \\
\hline $\begin{array}{l}\text { Cache formation: } \\
\text { Clay and gravel mixed, gray }\end{array}$ & 132 & 172 \\
\hline
\end{tabular}

13/7-21H1, L. G. Parker

[On alluvial plain. Reported by owner]

\begin{tabular}{l|r|r}
\hline & $\begin{array}{r}\text { Thickness } \\
\text { (feet) }\end{array}$ & $\begin{array}{c}\text { Depth } \\
\text { (feet) }\end{array}$ \\
\hline $\begin{array}{l}\text { Alluvium and Cache formation, undifferentiated: } \\
\quad \text { Silt and silt with gravel....... }\end{array}$ & 173 & 173 \\
$\begin{array}{l}\text { Cache formation: } \\
\text { Sand, black, main source of water....... }\end{array}$ \\
\hline
\end{tabular}

13/7-21J1, J. Berger

[On alluvial plain. Reported by owner]

\begin{tabular}{|c|c|c|}
\hline & $\begin{array}{c}\text { Thickness } \\
\text { (feet) }\end{array}$ & $\underset{\text { (feet) }}{\text { Depth }}$ \\
\hline $\begin{array}{l}\text { Alluvium: } \\
\text { Adobe } \\
\text { Hardpan } \\
\text { Sand and gravel. }\end{array}$ & $\begin{array}{r}5 \\
0.5 \\
19.5\end{array}$ & $\begin{array}{c}5 \\
5.5 \\
25\end{array}$ \\
\hline
\end{tabular}

\section{GROUND WATER}

The ground water of Burns Valley occurs in both the Recent alluvium and the Cache formation. The water levels in wells on the alluvial plain of Burns Valley range from about 5 to 15 feet below land surface, and have a seasonal variation of from 5 to 8 feet. Outside the alluvial plain, the water level is probably several tens of feet to more than 100 feet below the land surface, depending on the landsurface altitude. Periodic water-level measurements in two wells drilled through the alluvium and into the Cache formation of Anderson follow. Miscellaneous data are given in table 2. 
13/7-15Q1. F. Bartrum. On alluvial plain. About 1 mile northwest of four corners along the Ogelene Canyon Road, 0.12 mile west of half-section line, 63 feet north of road, in walnut orchard. Measuring point, top of casing at weld, 1.0 foot above land-surface datum, and about 1,385 feet above sea level.

Water levels, in feet below land-surface datum, 1949-52

\begin{tabular}{|c|c|c|c|c|c|}
\hline Date & $\begin{array}{l}\text { Water } \\
\text { level }\end{array}$ & Date & $\begin{array}{l}\text { Water } \\
\text { level }\end{array}$ & Date & $\begin{array}{l}\text { Water } \\
\text { level }\end{array}$ \\
\hline $\begin{array}{c}1949 \\
\text { Dec. 12 }\end{array}$ & 16 & $\begin{array}{l}1950-\text { Con. } \\
\text { Aug. } 23 .\end{array}$ & 11.46 & Apr. 27 1951 & 3. 15 \\
\hline $\begin{array}{l}1950 \\
\text { June } 13 . \\
\text { Aug. } 9\end{array}$ & $\begin{array}{r}7.60 \\
10.91\end{array}$ & $\begin{array}{l}\text { Nov. } 7 \\
\text { Dec. } 26\end{array}$ & $\begin{array}{r}11.81 \\
4.62\end{array}$ & Mar. 26 1952 & 0.29 \\
\hline
\end{tabular}

1 Measurement by U. S. Soil Conservation Service.

13/7-21H1. L. G. Parker. On alluvial plain. About 0.52 mile north of four corners, 170 feet west and 40 feet south from road intersection. Measuring point, top of casing at rivets, 0.6 foot above land-surface datum, and about 1,360 feet above sea level.

Water levels, in feet below land-surface datum, 1949-52

\begin{tabular}{|c|c|c|c|c|c|}
\hline Date & $\begin{array}{l}\text { Water } \\
\text { level }\end{array}$ & Date & $\begin{array}{l}\text { Water } \\
\text { level }\end{array}$ & Date & $\begin{array}{l}\text { Water } \\
\text { level }\end{array}$ \\
\hline $\begin{array}{c}1949 \\
\text { Dec. } 2 \ldots\end{array}$ & 124.95 & $\begin{array}{l}1950-\text { Con. } \\
\text { Aug. } 23 .\end{array}$ & 23.07 & Apr. 26 1951 & 18. 2 \\
\hline $\begin{array}{l}\text { Apr. } 6 \\
\text { Aug. } 9.50 \\
\end{array}$ & $\begin{array}{l}17.4 \\
20.49\end{array}$ & $\begin{array}{l}\text { Nov. } 7 \\
\text { Dec. } 26 . .\end{array}$ & $\begin{array}{l}23.65 \\
16.6\end{array}$ & Mar. 26 1952 & 11.01 \\
\hline
\end{tabular}

1 Measurement by U. S. Soil Conservation Service.

Significant differences between the water levels in shallow and deep wells have not been observed. Also, evidence has not been observed to indicate the existence of confined or artesian water within the Recent alluvium. However, some artesian head probably would be evident in deep wells that pass through clay beds in the Cache formation.

Almost all of the ground water of Burns Valley is derived from rain that falls within the $12 \frac{1 \%}{2}$ square miles of drainage area. As far as is known, all of it discharges into Clear Lake. Of course, wells at the lakeshore draw some water from the lake.

Assuming that the alluvium and Cache formation of Anderson are in hydraulic continuity, the ground-water body of Burns Valley extends for considerable distances in all directions beyond the alluvial plain, except to the northwest. Inasmuch as the Cache formation is at least 200 feet thick, the total volume of ground water in storage may be between 50,000 and 75,000 acre-feet. However, it would not be economically feasible either to unwater or to replenish most of this 
storage volume because of the nature of the terrane. Most of the ground-water withdrawals probably will be made from the alluvium, and will be replaced by movement of water from the reservoir outside the alluvial plain and from the lake. Therefore, water levels beneath the plain would not decline rapidly, even though the rate of natural replenishment were exceeded. Assuming a specific yield of 8 percent and an average decline of water levels of 50 feet in the alluvial plain, which comprises about 1,000 acres, only about 4,000 acre-feet of storage space would be created.

Except for a narrow strip of land several hundred feet wide along the lakeshore, the ground water of Burns Valley appears to be satisfactory for irrigation and domestic use from the standpoint of its mineral content. A partial analysis of water from well $13 / 7-21 \mathrm{G} 1$, more than half a mile from the lake, is as follows: chloride, $6.9 \mathrm{ppm}$; hardness, $63 \mathrm{ppm}$; and specific conductance, 263 micromhos at $25^{\circ}$ C. This water appears to be of good quality. However, water from the lake, as has been indicated, may contain boron in amounts harmful to plants. Also, several wells drilled within a few hundred feet of the lake have been destroyed because the water obtained had a strong "soda" taste.

\section{POSSIBILITY OF FURTHER DEVELOPMENT}

Little use has been made of the ground water of Burns Valley. Before 1936 only a few acre-feet of water per year was pumped; from 1936 through 1947, not more than 10 acre-feet per year; during 1948 , about 20 acre-feet; and during 1949 , about 30 acre-feet. Of this total, only a few acre-feet per year has been pumped for domestic use. Most of the pumpage was by wells $13 / 7-21 \mathrm{G} 1$ and $13 / 7-21 \mathrm{H} 2$. Well $13 / 7-21 \mathrm{H} 1$ pumped slightly less than 2 acre-feet per year. Pumpage by all other wells in the valley has been very small.

The deposits that underlie and surround Burns Valley are water bearing, although not highly permeable; accordingly, ground water in moderate quantities probably can be obtained from any properly constructed well that is deep enough, except along the margin of the alluvium in sec. 16 where rocks of the Franciscan group would be penetrated. The water-yielding properties of the volcanics in the immediate vicinity of Clearlake Park are not known. Data are insufficient for estimating the quantity of water that could be withdrawn yearly without depleting the natural supply; however, withdrawals probably could be increased many times what they are at present.

\section{BORAX LAKE BASIN}

Borax Lake (pl. 1) lies in a closed basin from 1 to 2 miles northwest of Clearlake Park. The total drainage area covers about 21/2 square 
miles, or about 1,600 acres. Nearly all of the basin floor is occupied by Borax Lake, a shallow intermittent lake surrounded by a narrow band of alluvium. Borax $\left(\mathrm{Na}_{2} \mathrm{O} \cdot 2 \mathrm{~B}_{2} \mathrm{O}_{3} \cdot 10 \mathrm{H}_{2} \mathrm{O}\right)$ was first discovered here in 1856 (Whitney, 1865, p. 98), and by 1890 much of it had been mined from the lake. The evaporated salts contain 62 percent sodium carbonate, 20 percent sodium cbloride, and 18 percent borax (Lindgren, 1933, p. 326). A few pilings standing on the lake bed are all that remain of the old workings. The only development of ground water consists of shallow wells that supply several ranches with water for domestic and stock use.

The alluvial plain of Borax Lake and the adjacent alluvial fans are underlain by the metamorphosed sediments of the Franciscan group. Borax Lake and Burns Valley are separated by lava flows of olivine dacite (Anderson, 1936) overlain by lava flows of rhyolite-obsidian.

Borax Lake now occupies the headward part of a southeastwardtrending valley excavated in the Franciscan group. Evidently, this valley was at one time continuous with Burns Valley, both draining into Clear Lake. According to Anderson $(1936$, p. 654 ), the outlet of the valley was dammed during Recent time, first by olivine dacite flows and later by the lava flows of rhyolite-obsidian, creating the lake.

Small streams draining the hillsides deposited alluvial fans that form the narrow band of alluvium around the lake. The most extensive alluvium covers about 150 acres at the east end of the lake. The slopes of the fans are fairly steep, but they probably do not contain much coarse-grained material. Beneath and near the lake the deposits probably consist mostly of silt and sand. Their thickness is not known, but it probably ranges from 50 to 75 feet.

In most of the area the alluvium rests on rocks of the Franciscan group, which are not water bearing, and at the southeastern end of the basin, against volcanic rocks. As far as is known, these rocks have not been drilled and nothing is known of their water-bearing properties.

Wells drilled into the alluvial fans at most places can be expected to yield water for domestic or stock use. Wells situated much above the level of Borax Lake are not likely to have large yields, and wells situated close to the lake are likely to obtain water with a high boron content, which would be toxic to most plants. Therefore, the possibility of developing irrigation wells in this area is poor.

\section{VALLEY EAST OF CLEARLAKE OAKS}

PHYSICAL AND CULTURAL FEATURES

Near Clearlake Oaks a narrow unnamed valley (pl. 1), which is actually part of the Clear Lake basin, extends eastward from the 
lake. Its total drainage area covers about 4,000 acres, of which nearly 1,000 acres is alluvial plains. The valley has two parts. The western part, about 800 acres in extent, is mostly lake plain, which is. bordered on the north and south by steep hillsides. Schindler Creek, the intermittent outlet of High Valley drainage, descends in a steep. gorge to the north side of the lake plain. In a narrow pass at the easternmost edge of this part of the valley, the lake plain merges. with the eastern part of the valley. The floor of the eastern part is. a sloping alluvial plain about 2 miles long and less than half a mile in maximum width. State Highway 20 traverses both parts of the valley from the "Williams Wye" near the eastern end to Clearlake Oaks at the extreme western margin of the lake plain. There are no. irrigation wells in this area, and only a few domestic wells. The only well that is known in the eastern part is $13 / 7-3 \mathbf{B} 1$, which supplies a gasoline station with less than 200 gallons of water per day. On the lake plain of the western part, some land near Clearlake has been reclaimed and is irrigated by pumpage from the lake. Information as to the quality of this water is not available. Residents of the area, which includes the town of Clearlake Oaks, obtain water from domestic wells.

The entire drainage area of this valley is underlain by rocks of the non-water-bearing Franciscan group, except for a few isolated small bodies of fragmental volcanic rocks. Therefore, the alluvium is the only water-bearing formation of consequence. Little information on its lithology and thickness is available, but it is probably not more than a few tens of feet thick, and most of it is probably fine grained. Although in the eastern part the alluvium is not tapped by wells, small supplies of domestic water probably could be obtained. Several shallow wells (see $\log$ of well $14 / 7-32 \mathrm{D} 1$ ) are reported to penetrate some gravel. Near the margins of the alluvium some coarse gravel would be expected in the deposits of steep streams, such as Schindler Creek. Wells drilled in the alluvium of the western part of the valley yield adequate amounts of water for domestic use, but it is not known if water is available in amounts sufficient for irrigation.

Log of well 14/7-32D1, Bradson

[On alluvial plain]

\begin{tabular}{|c|c|c|}
\hline & $\begin{array}{l}\text { Thickness } \\
\text { (feet) }\end{array}$ & $\begin{array}{l}\text { Depth } \\
\text { (feet) }\end{array}$ \\
\hline 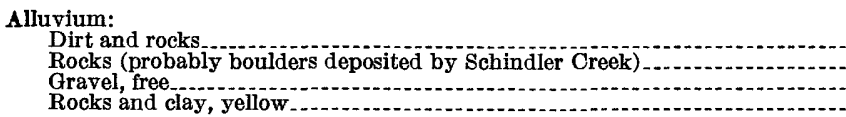 & $\begin{array}{r}17 \\
9 \\
1 \\
5\end{array}$ & $\begin{array}{l}17 \\
26 \\
27 \\
32\end{array}$ \\
\hline
\end{tabular}




\section{GROUND WATER}

Near Clear Lake the depth to water is at most places less than 25 feet. As far as is known, the water is not confined. Except for seepage from the lake, the source of ground water is rainfall within the drainage area. This area is small, however, so little water goes into storage. Also, the alluvium probably does not yield water readily. During winter rains, water from High Valley flows down Schindler Creek, but most of it passes directly into Clear Lake.

The quality of the ground water is poor. Water from well $13 / 7$ $3 \mathrm{~B} 1$ is reported to have a high soda and iron content. Some domestic wells in the western part of the valley have been destroyed because the taste of the water was so unpleasant. The lake water is also unsatisfactory; it is reported that grain irrigated at the Bradley ranch by water from Clear Lake was "killed by some chemical in the water," which may have been boron (see p. 56-57).

Thus, it is not likely that ground-water development can be much increased in this valley.

\section{HIGH VALLEY}

\section{PHYSICAL AND CULTURAL FEATURES}

High Valley (pl. 1) is a nearly closed, somewhat isolated basin lying immediately north of Clearlake Oaks. It consists of a flat or gently sloping alluvial plain about 3 miles long and 1 mile in average width (about 2,000 acres) surrounded by a narrow band of high, steeply sloping hills, except at the east end. The total drainage area is about 12 square miles. The central alluvial area is about 400 feet above the level of Clear Lake, which accounts for the name "High Valley". Short, steep intermittent creeks drain the surrounding hillsides, most of them terminating within the alluvial plain. In winter, when there has been enough rain, the water will form pools on the plain and flow in shallow channels to the head of Schindler Creek, an intermittent creek, then drain into Clear Lake near Clearlake Oaks. Some of the water remains on the plain, particularly at the extreme eastern end of the valley, forming temporary swamps.

There are no towns nor through highways in the valley, but there are several ranches and small farms. Much of the alluvial plain is cultivated and dry-farmed, grain being the principal crop. Development of water is limited to domestic wells of low production and to two sumps, one of which is used for irrigation of pasture. Where natural conditions have not been disturbed, the alluvial plain is covered with native grasses and spotted with oak trees; the hills are covered with chaparral. 


\section{GEOLOGY}

High Valley is the headwater remnant of a larger valley which extended eastward and was a tributary of the North Fork of Cache Creek. This valley was eroded in silicified sandstones and shales of the Franciscan group which compose the hills on the north and south sides and the west end. Subsequently, the valley was dammed by the extrusion of andesitic volcanics, apparently from the vicinity of Round Mountain. The resulting closed depression was partly filled by alluvial fans of the side streams to make the present alluvial floor. Schindler Creek, cutting headward from. Clear Lake, has breached the hills that border the south side of the valley, and, aided by continuing deposition of alluvium in High Valley has captured its drainage.

The surface of the alluvium in the central part of High Valley is flat and poorly drained. Two small remnants of a swampy lake that once covered the valley floor still exist, one at the east end and one at the west end of the alluvial plain. Thus, at least the uppermost material was deposited as a swamp or lake fill behind the lava dam across the eastern end of the valley. As would be expected, part of the alluvium is fine grained. The soil on the deposits, called Klamath silty clay loam, has been described by Carpenter, Storie, and Cosby (1931, p. 35-36) as follows: "The substratum to a depth of 22 or more inches consists of extremely compact bluish-gray, dense, waxy clay $* * *$ in need of drainage, though it is doubtful if drainage would pay, even if it were possible $*^{*} *$ on account of the tightness and imperviousness of the subsoil".

The central part of the alluvial plain is bordered by alluvial fans, which contain material that is coarser grained and better drained. Carpenter, Storie, and Cosby (1931, p. 20-21) describe the soil on these deposits as follows: "The Rincon gravelly sandy loam $* * *$ occupies alluvial fans throughout the area $* * *$ Surface drainage and subdrainage under natural conditions are well developed. Wellrounded gravel of medium size constitutes 15 or 20 percent of the soil mass. The gravels in the subsoil are similar to those in the surface soil and compose about the same proportion of the soil mass".

In the NW $1 \frac{1}{4} \mathrm{NW} 1 \frac{1}{4}$ sec. 19, T. 14 N., R. 7 W., on Stice's ranch, a sump 15 or 20 feet deep was dug on the toe of the alluvial fan. It penetrated some clay and gravel in the first few feet, but the formation is mostly non-water-bearing clay. Some of the clay is massive, and some is finely bedded with prints of organic matter. Near the top of the sump are two seams of white volcanic ash or dust, each about 6 inches thick. The ash has an index of refraction of 1.51 and is uniformly fine grained. 
In the $\mathrm{NE}_{1 / 4}^{1 / 2 E} \mathrm{NE}_{4}^{1 / 4}$ sec. 25 , T. $14 \mathrm{~N}$., R. 8 ,W., on Warren's ranch, two sumps were dug about 16 feet deep. Except for some fine sand in the bottom, these sumps were dug entirely in clay. Ash beds are not exposed on the sump walls.

All wells in High Valley are shallow and start in the alluvium. Only two wells definitely penetrate bedrock; a third well may penetrate it. The deepest well in the central part of the valley, 14/824J1, 94 feet deep, drilled in the bottom of a 37-foot pit, did not penetrate consolidated rock. Logs of these wells follow:

\section{Logs of wells in High Valley}

14/8-13P1, D. Baker

[On alluvial fan. Reported by former owner]

\begin{tabular}{l|r|r}
\hline & $\begin{array}{r}\text { Thickness } \\
\text { (feet) }\end{array}$ & \multicolumn{1}{c}{$\begin{array}{c}\text { Depth } \\
\text { (feet) }\end{array}$} \\
\hline $\begin{array}{l}\text { Alluvium: } \\
\text { Soil and rock........ }\end{array}$ & 100 \\
Franciscan group & \\
\hline
\end{tabular}

14/8-24B1, D. Baker

[On alluvial fan near central part of alluvial plain. Reported by former owner]

\begin{tabular}{|c|c|c|}
\hline & $\begin{array}{c}\text { Thickness } \\
\text { (feet) }\end{array}$ & $\begin{array}{l}\text { Depth } \\
\text { (feet) }\end{array}$ \\
\hline $\begin{array}{l}\text { Alluvium: } \\
\text { Soil and rock }\end{array}$ & \multirow{3}{*}{$\begin{array}{l}75 \\
25 \\
21\end{array}$} & \multirow{3}{*}{$\begin{array}{r}75 \\
100 \\
121\end{array}$} \\
\hline Clay, some gas in formation. & & \\
\hline Franciscan group. & & \\
\hline
\end{tabular}

14/8-24J1, E. F. Berger

[On central part of alluvial plain about 1,000 feet northeast of well 14/8-24J2. From driller's records]

\begin{tabular}{|c|c|c|}
\hline + & $\begin{array}{c}\text { Thickness } \\
\text { (feet) }\end{array}$ & $\begin{array}{c}\text { Depth } \\
\text { (feet) }\end{array}$ \\
\hline $\begin{array}{l}\text { Alluvium: } \\
\text { Old dug well } \\
\text { Clay } \\
\text { Gravel, pea size. }\end{array}$ & $\begin{array}{r}37 \\
53 \\
4\end{array}$ & $\begin{array}{l}37 \\
90 \\
94\end{array}$ \\
\hline
\end{tabular}

14/8-24J2, E. F. Berger

[On central part of alluvial plain. Reported by owner]

\begin{tabular}{|c|c|c|}
\hline & $\underset{\text { (feet) }}{\text { Thickness }}$ & $\begin{array}{l}\text { Depth } \\
\text { (feet) }\end{array}$ \\
\hline $\begin{array}{l}\text { Alluvium: } \\
\text { Material undescribed }\end{array}$ & 65 & 65 \\
\hline $\begin{array}{l}\text { Gravel } \\
\text { Sandstone (may be Franciscan group) }\end{array}$ & $\begin{array}{r}17 \\
5\end{array}$ & $\begin{array}{l}82 \\
87\end{array}$ \\
\hline
\end{tabular}


From an examination of well logs, sumps, and physical features, it appears that the central part of the alluvium of High Valley is composed of clay, some sand or silt, and probably an occasional bed of gravel. These deposits interfinger with somewhat coarser grained, but less well-sorted, alluvial-fan material along the sides of the valley. The maximum thickness of this alluvium is unknown, but it is probably slightly more than 100 feet. At least the upper deposits of the central part of the alluvium are sufficiently fine grained to prevent the ready downward percolation of water from the surface, and they may confine water beneath them. The specific yield of this material is very low. Most of the beds of gravel are probably at greater depth.

The Franciscan rocks, which nearly surround High Valley, are not water bearing. Little is known about the volcanic flows, but they appear to be somewhat jointed and may absorb and transmit considerable water in fractures or in rubbly zones between flows.

\section{GROUND WATER}

Nearly all of the water used in High Valley is pumped from wells dug or drilled in the alluvium. Periodic water-level measurements in three wells follow. Miscellaneous data are given in table 2.

14/7-19M1. J. F. Harty. On alluvial plain. About 0.2 mile west of $90^{\circ}$ turn in road, 150 feet northwest of cement-block house, 30 feet south of center line of road. Measuring point, top of casing south side, 0.6 foot above landsurface datum, and about 1,730 feet above sea level.

Water-levels, in feet below land-surface datum, 1950-52

\begin{tabular}{|c|c|c|c|c|c|}
\hline Date & $\begin{array}{l}\text { Water } \\
\text { level }\end{array}$ & Date & $\begin{array}{l}\text { Water } \\
\text { level }\end{array}$ & Date & $\begin{array}{l}\text { Water } \\
\text { level }\end{array}$ \\
\hline \begin{tabular}{l}
\multicolumn{1}{c}{1950} \\
June 14 \\
Aug. 7 \\
Aug. $23 . \ldots$
\end{tabular} & $\begin{array}{l}17.50 \\
21.08 \\
18.20\end{array}$ & $\begin{array}{l}\text { 1950-Con. } \\
\text { Oct. } 11 \text {. } \\
\text { Nov. } 11 \\
\text { Dec. } 26\end{array}$ & $\begin{array}{l}18.65 \\
18.60 \\
16.61\end{array}$ & $\begin{array}{c}1951 \\
\text { Apr. 27 } \\
\text { Mar. 26 }\end{array}$ & $\begin{array}{l}15.64 \\
12.78\end{array}$ \\
\hline
\end{tabular}

14/8-24B1. D. Baker. On alluvial fan, 0.4 mile north of road, on concrete slab about 150 feet southwest of ranch house. Measuring point, top of casing north side, 0.6 foot above land-surface datum, and about 1,800 feet above sea level.

Water levels, in feet below land-surface datum, 1949-52

\begin{tabular}{|c|c|c|c|c|c|}
\hline Date & $\begin{array}{l}\text { Water } \\
\text { level }\end{array}$ & Date & $\begin{array}{l}\text { Water } \\
\text { level }\end{array}$ & Date & $\begin{array}{l}\text { Water } \\
\text { level }\end{array}$ \\
\hline Dec. 2 . 1949 & 165.4 & $\begin{array}{c}1950-\text { Con. } \\
\text { Aug. } 23 \ldots \ldots\end{array}$ & 61.31 & Apr. $27 \quad 1951$ & 21. 59 \\
\hline $\begin{array}{l}\text { June } 14 \ldots 50 \\
\text { Aug. } 7 \ldots \ldots\end{array}$ & $\begin{array}{l}44.14 \\
58.20\end{array}$ & $\begin{array}{l}\text { Nov. } 7 \\
\text { Dec. } 26\end{array}$ & $\begin{array}{l}46.43 \\
59.43\end{array}$ & Mar. 26__. 1952 & 14. 26 \\
\hline
\end{tabular}

1 Measurement by U. S. Soil Conservation Service. 
14/8-24J1. E. F. Berger. On alluvial plain, 0.15 mile south of road, 50 feet west of dirt access road, 50 feet south of fence line. Measuring point, center of copper washer nailed on 2 -inch by 6 -inch board over well, 0.2 foot above landsurface datum, and about 1,740 feet above sea level.

Water levels, in feet below land-surface datum, 1950-52

\begin{tabular}{|c|c|c|c|c|c|}
\hline Date & $\begin{array}{l}\text { Water } \\
\text { level }\end{array}$ & Date & $\begin{array}{l}\text { Water } \\
\text { level }\end{array}$ & Date & $\begin{array}{l}\text { Water } \\
\text { level }\end{array}$ \\
\hline $\begin{array}{l}\text { 1950 } \\
\text { June } 30 \\
\text { Aug. 23 } \\
\text { Oct. } 1111 \\
\text { Nov. } 11 . \\
\end{array}$ & $\begin{array}{l}21.30 \\
22.50 \\
22.82 \\
22.08\end{array}$ & $\begin{array}{c}\text { Dec. } 26 \ldots 50-\text { Con. } \\
1951 \\
\text { Apr. } 27 \ldots \ldots\end{array}$ & 2. 66 & 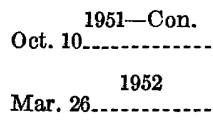 & 21.47 \\
\hline
\end{tabular}

Data are few, but they seem to suggest that the water levels in dug wells that are less than 26 feet deep stand within 4 to 10 feet of the land surface, and that the water levels in deeper wells stand at 20 to 60 feet below land surface. Exceptions are well 14/7-19M1 (table 2), reported to be 28 feet deep, in which the water level in June 1950 was 17.50 feet below land-surface datum; and well 14/8-24J1, 94 feet deep, in which the water level rose from a low of 23 feet in October 1950 to less than 3 feet in December 1950. Both of these wells are in the central part of the alluvial plain where some separation of water bodies would be expected on account of the fine-grained upper material. Possibly the restraining clays are only 25 to 30 feet thick, and are above a main deep water body. More data are needed to demonstrate a separation of water bodies.

It may be significant that in well $14 / 8-24 \mathrm{~J} 1,94$ feet deep, in the central part of the alluvial plain, the seasonal range in water levels is 20 feet or more. In well 14/8-24B1, 121 feet deep, near the central part of the plain, it was nearly 50 feet. This range cannot be caused by pumping because there is very little artificial draft on the groundwater body. Thus, there must be considerable natural summer discharge from the area. It is unlikely that Schindler Creek, the only surface outlet, carries all of this discharge. The creek is reported to flow only during the rainy season, and when observed on June 14, 1950, in the steep canyon crossing sec. 29 north of State Highway 20 near Clearlake Oaks, it was dry. The creek-bed gravel and alluvium are too thin to carry any significant quantity of underflow.

Therefore, it is possible that some of the ground-water discharge may pass eastward beneath the volcanics down the old buried valley. At least two perennial springs, $14 / 7-23 \mathrm{~J} 1$ and $14 / 7-24 \mathrm{~N} 1$, discharging at the base of one of the volcanic flows that dam High Valley, each had an estimated flow of about $25 \mathrm{gpm}$ in the autumn of 1950. Their altitude, about 1,575 feet, is low enough for them to carry ground- 
water discharge from High Valley. Of course, they may be fed in part by infiltration of rain on the surface of the volcanics. Spring 14/7-23B1, at an altitude of about 1,240 feet, is low enough to carry ground water from High Valley, but the discharge is only a few gallons per minute. This spring issues from fractures in a window of Franciscan rock in an area of volcanic flows. Spring 14/7-25P1 discharges as a slow seep from the volcanic flows and appears to have no relationship to the discharge of High Valley.

Partial analyses of water from springs east of High Valley, August 7, 1950

\begin{tabular}{|c|c|c|c|c|}
\hline Spring & $\begin{array}{c}\text { Chloride } \\
\text { (ppm) }\end{array}$ & $\underset{(\mathrm{ppm})}{\text { Hardness }}$ & $\begin{array}{l}\text { Specific } \\
\text { conduct- } \\
\text { ance } \\
\text { (microm- } \\
\text { hos at } 25^{\circ} \\
\text { c.) }\end{array}$ & $\begin{array}{l}\text { Tempera- } \\
\text { ture }\left({ }^{\circ} \mathrm{F}\right)\end{array}$ \\
\hline $\begin{array}{l}14 / 7-23 \mathrm{~B} 1 \\
14 / 7-23 \mathrm{~J} 1 \\
14 / 7-24 \mathrm{~N} 1\end{array}$ & $\begin{array}{r}985 \\
6.6 \\
7.7\end{array}$ & $\begin{array}{r}842 \\
82 \\
92\end{array}$ & $\begin{array}{l}714 \\
215 \\
255\end{array}$ & $\begin{array}{l}68 \\
64 \\
65\end{array}$ \\
\hline
\end{tabular}

From a comparison of the partial analyses of these waters it appears that spring $14 / 7-23 \mathrm{~B} 1$ has a different source from springs $14 / 7-23 \mathrm{~J} 1$ and $14 / 7-24 \mathrm{~N} 1$. Water from the first spring has too high a chloride content to be of use, whereas water from the other springs appears to be satisfactory for most uses.

As far as is known, analyses have not been made of the ground water of High Valley proper. The water appears to be suitable for domestic and agricultural purposes; however, water obtained in or near the volcanic rocks should be tested for boron.

Much is yet to be learned about the occurrence of the ground water of High Valley. Because the ground-water body may be continuous for several miles eastward beneath the volcanics, and because of the lack of data on the lithology of the deeper alluvium in High Valley proper, an attempt has not been made to estimate the storage capacity. The shallow alluvium appears to be relatively impermeable; therefore, replenishment of the ground-water body might be very slow, even though a large capacity might exist.

The source of the water in High Valley is precipitation that falls within the drainage area. However, inasmuch as most of the ground water may discharge eastward, the effective drainage area for water reaching the alluvial plain may be that part of the total area that lies west of Schindler Creek, an area of about 8 square miles $(5,000$ acres).

\section{POSAIBHITY OF FURTHER DEVELOPMENT}

Existing well logs are generalized, but they seem to indicate that most of the alluvium is fine grained and that it will yield enough water 
for domestic use, but probably not enough for irrigation. However, the full thickness of the alluvium has not been adequately explored; it might be worthwhile, therefore, to drill several test holes to bedrock at the center of the valley, where coarse gravel and a larger supply of water might be located below the fine sediments. Also, considerable water might be obtained from wells drilled through the andesites east of High Valley if gravels of the old High Valley creek are buried beneath the andesites. This land is rugged, however, and the water might have to be transported some distance before it could be used.

Although it is possible that properly constructed wells would yield more water than existing wells and that gravels might be penetrated beneath the fine sediments, the possibility of much further groundwater development in High Valley is not favorable.

\section{LONG VALLEY}

\section{PHYSICAL AND CULTURAL FEATURES}

Long Valley (pl. 1), the northernmost valley considered, lies about 5 miles north of Clearlake Oaks. Water from the area, about 34 square miles, is drained by Long Valley Creek, which joins the North Fork of Cache Creek. The alluvial plain is about 6 miles long and half a mile.wide, or about 2,000 acres in area, and in its natural state is covered with grass and large oak trees. A very dense growth of large, tall oak trees occurs along the main channel of Long Valley Creek. At the west end of the valley, the alluvial plain is bordered by hills slightly more than 2,000 feet high. Present development of ground water is limited to one 12 -inch irrigation well, $14 / 7-6 \mathrm{~F} 1$, at the Garner ranch.

\section{GEOLOGY}

The greater part of the drainage area of Long Valley is underlain by non-water-bearing silicified sandstone and shale of the Franciscan group. Except where breached by a narrow channel at the east end of the valley, these consolidated rocks completely surround the alluvial plain. Therefore, almost all drainage out of the valley comes to the surface. The central alluvial flood plain of Long Valley Creek is underlain by unconsolidated silt, sand, and occasional layers of gravel, derived from the weathering and erosion of the surrounding consolidated rocks. The alluvium is at least 200 feet thick; several test wells driven to that depth at the Garner ranch did not penetrate the underlying bedrock. This is the only water-bearing material of consequence in the drainage area.

The alluvial fans at the sides of the valley are narrow and steep and for the most part are above the zone of saturation; although they may be coarse grained, they would probably yield little water. The 
flood plain deposits, on the other hand, slope only about 25 feet per mile. Also, Long Valley carries, and probably carried all during the Pleistocene, numerous large rounded pebbles and cobbles. Residents report that most of the year the creek has a large flow for the full length of its course. During and after heavy rains this flow probably flushes much of the silt and finer material out of the channel gravels. Therefore, it is likely that thick deposits of these gravels occur below the zone of saturation and that they would yield considerable quantities of water if penetrated by wells.

\section{GROUND WATER}

Only a few wells have been drilled into the alluvium of Long Valley. Well 14/7-6F1, drilled in October 1949, is 90 feet deep, and was logged by the driller as penetrating silt, sand, and gravel. This well was first pumped on June 17, 1950. Periodic water-level measurements follow. Miscellaneous data are given in table 2.

14/7-6F1. Fred Garner. On alluvial plain. About 500 feet west of dwelling, 10 feet north of fence line, on concrete slab. Measuring point, base of pump southeast corner, 1.0 foot above land-surface datum, and about 1,330 feet above sea level.

Water levels, in feet below land-surface datum, 1949-52

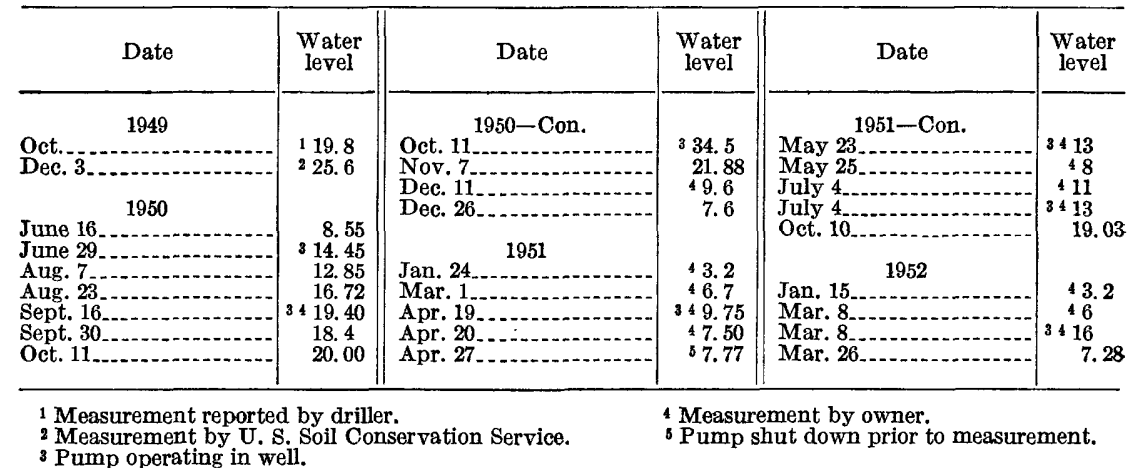

Fred Garner reports that before 1900 his father drove three 2-inch test wells near the ranch house. One was about 200 feet deep and flowed at a rate of about $2 \mathrm{gpm}$. However, the water had such a high "soda" content that it was unusable for domestic purposes, and the well was destroyed. The other two wells, which were about the same depth, did not flow or contain noticeable amounts of "soda"; they were also destroyed. The present 90 -foot irrigation well, about 500 feet south of the old test holes, does not flow and does not contain noticeable amounts of objectionable salts. It may be that the flowing test well tapped a deep water body of poor quality that was under low artesian head. The following table indicates that the water in the irrigation well and in Long Valley Creek is of satisfactory quality. 
Partial analyses of water in Long Valley, 1950

\begin{tabular}{|c|c|c|c|c|}
\hline Source & $\begin{array}{c}\text { Date } \\
\text { sampled }\end{array}$ & $\underset{\text { (ppm) }}{\text { Chloride }}$ & $\begin{array}{l}\text { Hard- } \\
\text { ness } \\
\text { (ppm) }\end{array}$ & $\begin{array}{c}\text { Specific } \\
\text { conduct- } \\
\text { ance } \\
\text { (micromhos } \\
\text { at } 25^{\circ} \mathrm{C} \text { ) }\end{array}$ \\
\hline $\begin{array}{l}\text { Well 14/7-6F1 } \\
\text { Long Valley Creek }\end{array}$ & $\begin{array}{l}\text { June } 29 \\
\text { Aug. } 7\end{array}$ & $\begin{array}{l}3.9 \\
1.7\end{array}$ & $\begin{array}{l}80 \\
80\end{array}$ & $\begin{array}{l}662 \\
213\end{array}$ \\
\hline
\end{tabular}

With the possible exception of deep water tapped by the now destroyed flowing test well, it would appear that the ground water in the central part of Long Valley is unconfined, and that water in the creek can readily percolate downward to the ground-water body. The log of the Garner ranch irrigation well does not indicate a thick stratum that might act as a confining bed. However, confining conditions may exist in other parts of the valley.

All of the ground water is derived from rain that falls within the drainage area. Water does not percolate from other basins. Except at well $14 / 7-6 \mathrm{~F} 1$ (see p. 72 ), the depth to water throughout the valley is not known. Because of the near perennial flow of Long Valley Creek, and because of the similarity of vegetation over the flood plain, it is believed that water levels are between 10 and 30 feet beneath the surface throughout the year. Assuming that the saturated alluvium is 100 feet thick with a specific yield of 10 percent, and that its areal extent is 2,000 acres, the total amount of ground water in storage would be about 20,000 acre-feet.

\section{POSSIBIIITY OF FURTHER DEVELOPMENT}

Considerably more water for irrigation and domestic use can probably be developed in Long Valley. The well at the Garner ranch yielded about $480 \mathrm{gpm}$ for 10 to 12 hours a day during most of the summer of 1950. The alluvial gravels of Long Valley Creek, from which it draws, extend several miles up and down the stream from the Garner ranch and could be tapped by other properly located wells.

The total amount of water available for replenishment of the groundwater body constitutes the maximum development that can be expected. However, there is little information on which to base an estimate. About 30 inches of rain per year, or about 55,000 acrefeet of water, falls on the 22,000 acres of the Long Valley drainage area. Much of it is absorbed by vegetation, and of the remainder, the greater part probably runs off during storms. Therefore, only a small percent of the water that falls within the drainage area is actually available to replenish the ground-water body.

The maximum development can also be estimated from the natural discharge. Under natural conditions the total inflow must equal the 
total outflow for a given period, plus or minus the change in groundwater storage for that period. Inasmuch as the pumping draft is negligible in Long Valley, the change in ground-water storage is assumed to be negligible, also. Accordingly, the total amount of water available is equal to the natural discharge.

The discharge consists of evapotranspiration and of surface runoff in Long Valley Creek. Since 1930, the U. S. Geological Survey has. maintained a gaging station on the North Fork of Cache Creek, about. 2 miles below the mouth of Long Valley Creek. The median annual runoff for the water years 1931-50 from the 198 square miles of drainage area above the gage was 78,000 acre-feet per year. The runoff from Long Valley Creek, prorated according to its 34 square miles of drainage area, is about 13,000 acre-feet. (See table 5.)

The discharge of Long Valley Creek at a measuring site in the $\mathrm{SE}_{1 / 4}^{1 / \mathrm{NE}_{1 / 4}}$ sec. 15 , T. $14 \mathrm{~N}$., R. $7 \mathrm{~W}$., was about 1 second-foot as. measured on June 29, 1950, 0.25 second-foot on August 7, and about 0.2 second-foot on October 11 . There was no surface runoff across the main part of the valley during the period of these measurements; hence all of the discharge was ground water. However, the measurements are not representative of long-term average conditions, 1950 being a year of below average rainfall; the discharge would be considerably higher in an average year. It is reported that during previous years, side channels in the vicinity of the measuring site have flowed much later in the season than at present. However, there are times when Long Valley Creek has no flow. The average low-water discharge may be about 1 second-foot or about 700 acrefeet a year. Therefore, the total water available annually is between 700 and 13,000 acre-feet. These figures might be increased slightly by the amount of evapotranspiration loss that would be salvaged through the lowering of summer water levels if pumpage were substantially increased. The amount of increase is probably small and is not considered here.

It would not be possible to pump the amount of water that is discharged. However, by lowering the water table so as to induce additional seepage from the creek in winter, it would seem entirely possible to obtain several times the low-water discharge. Considering that the 200-foot flowing well that was driven before 1900 was reported to yield water of unpleasant taste, it is possible that at depths greater than 100 feet some of the water will be of poor quality. 


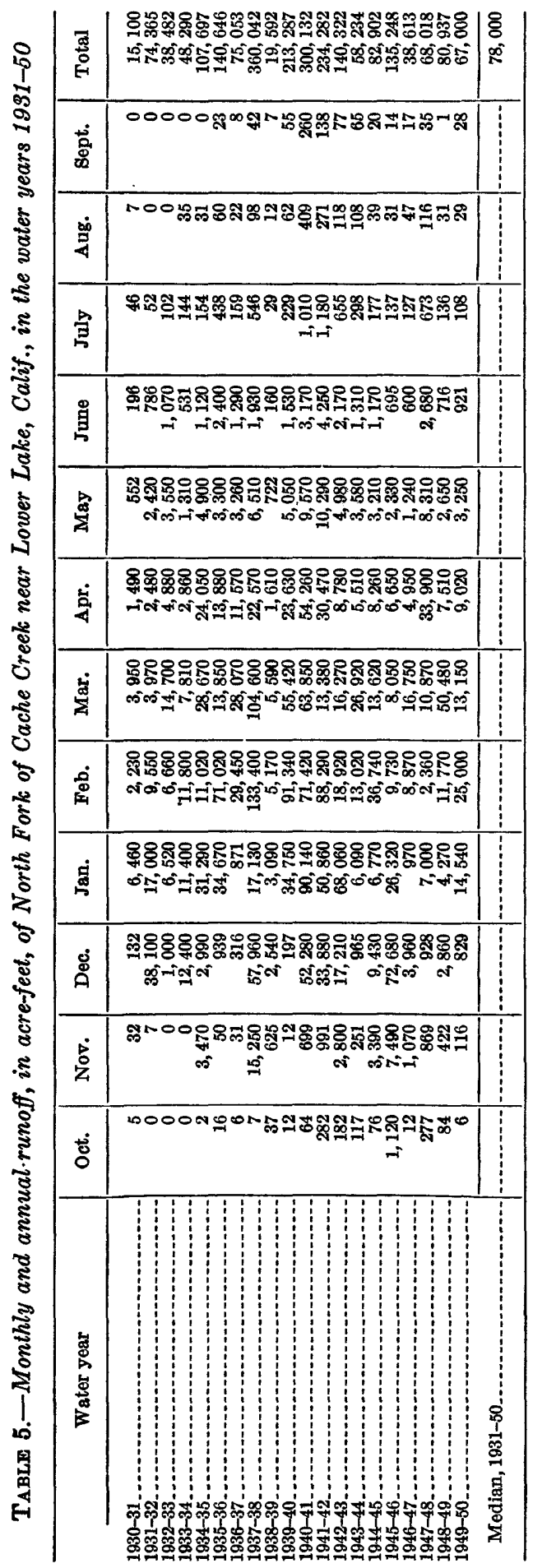




\section{UTILIZATION OF A GROUND-WATER BASIN}

Some of the valleys of the Lower Lake-Middletown area show promise of being able to support considerable further development, whereas others do not. In most of the valleys the ground water is relatively undeveloped. Nevertheless the construction of a few irrigation wells, with the observed or anticipated decline of water levels, has caused some ranchers to fear that their water supply will be impaired. However, some decline of water levels is necessary if a large amount of water is to be taken from the ground.

The ground-water reservoirs in most valleys of the Lower LakeMiddletown area can be likened to a pitcher that is filled with gravel, sand, silt, and clay, and that contains water up to a certain level. The consolidated bedrock corresponds to the sides and bottom of the pitcher, and the gravel, sand, silt, and clay correspond to the alluvial fill. The ground-water body is the water in the pitcher, and the water table is the top of the saturated zone. Actually, natural reservoirs are more varied and complicated. The basin filling may consist partly of lava flows and volcanic tuff, and there may be several kinds and ages of alluvium. Also, some of the water may be confined and under artesian head, and at places the water level may coincide with or be above the land surface.

Under natural conditions the level of the ground water remains about constant or fluctuates within relatively narrow limits, depending on the prevailing balance between inflow and outflow. If the outflow is greater than the inflow, as it ordinarily is in California groundwater basins during summer, the water level declines slightly. If the outflow is less than the inflow, as it is in winter, the water level rises.

When irrigation wells are added to this system, summer water levels will decline more than they will under natural conditions. However, this is not necessarily a cause for concern. In order for water to flow toward a well, the water level in the well must be lower than it is in the surrounding material. By artificially lowering the water level, space is created for storage of much or all of that part of the following winter's precipitation that is available for replenishment of the ground-water body. If the water level is not artificially lowered, little storage space will exist, and much of this available water will be discharged and lost for future use.

The critical point is whether or not the water levels recover after the pumping season, or after several pumping seasons if in a series of dry years. The average amount of water that can be pumped out of a ground-water reservoir year after year without permanently depleting the supply, without exceeding the natural rate of inflow, without lowering water levels below the economic limit of pumping 
lift, and without drawing in water of deleterious chemical quality has to be determined separately for each ground-water basin. This amount is called the safe yield of the basin. Its determination depends on many factors that often require records of several years of pumpage, water-level changes, rainfall, runoff, and other elements.

By knowing the safe yield, an orderly and efficient development of a ground-water basin can be made. Not enough data are available at present to determine the safe yield for basins in the Lower LakeMiddletown area. It appears that the safe yield of all of these basins, except possibly Excelsior Valley, has not been approached. Nevertheless, continued measurements of water levels in wells, stream discharge, and rainfall, and the collection of drillers' logs and the taking of water samples for chemical analysis ought to be accomplished before water problems arise. With these data the safe yield will be easier to determine and water problems will be easier to solve.

\section{METHODS OF DRILLING AND DEVELOPING WELLS IN THE LOWER LAKE-MIDDLETOWN AREA}

Most of the wells in the Lower Lake-Middletown area have been dug by hand or drilled by small rigs using the percussion, or cabletool, method. Many of the existing domestic wells were dug and lined with stone or brick by the original homesteaders of the several ranches. Very few of these old dug wells have been deepened by the present owners. Thus, the water levels have not declined greatly since the wells were dug. Some of the new wells are hand dug, but most wells for domestic use are now drilled by cable tools. At present most irrigation wells are actually shallow sumps dug by a dragline in the gravel channels of the creeks.

Most wells that have been developed by these methods are satisfactory for domestic use or small-scale irrigation. However, extensive development of irrigation in most of the valleys would probably cause a lowering of the water table during the summer months to such a depth that the excavated sumps would have to be deepened beyond practical limits if they were to be used. Eventually it will be necessary to drill the irrigation wells. Also, higher yields probably can be obtained if somewhat different drilling methods are used. ${ }^{4}$

Shallow wells are usually drilled by percussion, or cable-tool, rig. A perforated casing is driven into the hole a few feet at a time as the drilling progresses. Perforations are usually cut on the job by a welding torch, and are about half an inch wide and about 6 inches long. Driving preperforated casing, especially into the fine-grained deposits that are characteristic of the Lake County areas, frequently

( See selected bibliography, p. 80 . 
results in the perforations stopping opposite clay beds from which little water can be obtained or opposite sand that readily runs through the large perforations, allowing the well to sand-up. Therefore, in cable-tool holes that are not gravel packed, it is preferable to perforate the casing after it is in the hole so as to place the perforations opposite the coarse-grained water-yielding strata.

In order to know where these strata are, a log should be kept. Some details regarding logs are given in sections 7076-7078 of the California State Water Code, which require that logs of all water wells be kept and reported. A log should be a permanent record showing the type, thickness, and depth below land surface of the materials penetrated. Size of sand and gravel should be noted. Also, the occurrence and color of clays, silts, and other rock types should be carefully recorded. On the basis of the log, the driller can determine what sections of the casing to perforate and what width of perforation would be most suitable to the coarseness and sorting of the water-bearing material. In general, perforations should not be wider than the median gravel or sand size and not so narrow that they become clogged, although other factors are involved. Also, the casing should not be perforated opposite some strata, such as quicksand and clay.

It is desirable that wells drilled into the alluvium of the Lower Lake-Middletown area be drilled to the base of that formation. It is also desirable that the drilling be continued into the underlying non-water-bearing consolidated rock until the driller is satisfied that he has definitely penetrated the consolidated rock, and not merely a large boulder in the alluvium. However, owners often order that drilling be stopped as soon as a sufficient supply of water is tapped. This may save a few dollars at the time of drilling, but for maximum yield the formation must be penetrated to its base. Owners and drillers report that most wells of the Lower Lake-Middletown area bottom in a water-bearing formation, commonly gravel. As a general rule, it is desirable to bottom a well in clay or bedrock.

A good method for locating the site of a well is to drill a series of small-diameter uncased test holes to bedrock in the places most likely to yield water, keeping accurate logs of each. On the basis of these data the best hole can be selected; it can then be reamed to a larger diameter and developed for use. In some circumstances the drilling of a test hole is not practical, but even if only one well is to be drilled it is essential that an accurate log be kept for proper development of the well.

After the bole is drilled and the casing is placed, it is not desirable immediately to set the pump intended for use into the well. If a period of development is allowed for a well that is properly con- 
structed, less sand will collect in the well and the yield will be greater than if a period of development is not allowed. The most common methods of development are surging, overpumping, and backwashing.

Development by surging is best suited to wells drilled by cabletool rigs. A tight-fitting plunger attached to a heavy drill stem is lowered into the well about 15 feet below the static water level. With the longest stroke possible, the tool is worked up and down. The motion should be slow at first, then gradually speeded up. An attempt should be made to get the period of the stroke in phase with the surge of the water in the well. This action forces the water in and out of the sand and gravel beds, washing the finer particles into the well where they are removed by bailing. Alternate surging and bailing is continued until sand is no longer washed into the well. In certain formations, surging causes the packing of gravel around the casing.

Development of a well by overpumping is to pump the well at a higher rate than that at which the well will be pumped when in regular use. If this is the only method used to develop the well, it should be continued until the water clears. Sometimes many days are required. Although a well cannot be completely developed by overpumping alone, the method is satisfactory if regular pumping is to be at a rate less than that for maximum yield.

There are several methods of back-washing, but the general principle is to create the greatest change in the water level of the well in the shortest time possible. The simplest way of doing this is to operate the pump at its maximum capacity until the maximum drawdown has been achieved. The pump is then stopped. Water in the pump column rushes toward the well, agitating the sand and gravel in the formation and washing the finer material into the well. This process is repeated until the water is clear.

Development of a well by back-washing is satisfactory, but it must be done with caution. When the operator starts the turbine pump, the rotation of the pump should be slow, and gradually increased to the maximum rate. Starting the pump at too rapid a rate may cause such a large quantity of sand to be drawn suddenly into the well that the pump will lock. The operator must make sure when restarting the pump that there is no water flowing down the pump column causing the pump shaft to revolve backwards. If the shaft is revolving backwards at this time, it may break.

Local conditions will determine which method or combination of methods is most satisfactory for development of a well to its maximum yield. 


\section{SELECTED BIBLIOGRAPHY}

Anderson, C. A., 1936, Volcanic history of the Clear Lake area, California: Geol. Soc. America Bull., v. 47, no. 5, p. 629-664.

Becker, G. F., 1888, Geology of the quicksilver deposits of the Pacific slope: U. S. Geol. Survey Mon. 13.

Bennison, E. W., 1947, Ground water, its development, uses and conservation: 509 p., St. Paul, E. E. Johnson, Inc.

Bowman, Isaiah, 1911, Well-drilling methods: U. S. Geol. Survey Water-Supply Paper 257, $139 \mathrm{p}$.

Brice, J. C., 1954, Geology of the Lower Lake quadrangle: Calif. Div. Mines Bull. 166.

Carpenter, E. J., Storie, R. E., and Cosby, S. W., 1931, Soil survey of the Clear Lake area, California: U. S. Dept. Agriculture, Bur. Chemistry and Soils, ser. 1927, no. 13.

Davis, W. M., 1933, The lakes of California: Calif. Jour. Mines and Geology, v. 29 , nos. 1-2, p. 175-236.

Dickerson, R. E., 1914, Fauna of the Martinez Ecocene of California: Calif. Univ., Dept. Geol. Sci. Bull., v. 8, no. 6, p. 61-180.

Forstner, William, 1903, Quicksilver resources of California: Calif. Min. Bur. Bull. 27.

Jenkins, O. P., 1938, Geologic map of California: Calif. Div. Mines.

Lindgren, Waldemar, 1933, Mineral Deposits: 4th ed., 930 p., New York and London, MeGraw-Hill Book Co., Inc.

Poland, J. F., Davis, G. H., Olmsted, F. H., and Kunkel, Fred, 1951, Groundwater storage capacity of the Sacramento Valley, Calif., in Water Resources of California: Calif. Water Res. Board Bull. 1, app. D, p. 617-632.

Rohwer, Carl, 1940, Putting down and developing wells for irrigation: U. S. Dept. Agriculture Circ. 546.

Taliaferro, N. L., 1943a, Franciscan-Knoxville problem: Am. Assoc. Petroleum Geologists Bull., v. 27, no. 2, p. 109-219.

$1943 \mathrm{~b}$, Geologic history and structure of the central Coast Ranges of California: Calif. Div. Mines Bull. 118, p. 119-163.

Waring, G. A., 1915, Springs of California: U. S. Geol. Survey Water-Supply Paper 338, $410 \mathrm{p}$.

Weaver, C. E., 1949, Geology of the Coast Ranges immediately north of the San Francisco Bay region, California: Geol. Soc. America Mem. 35, 242 p.

Whitney, J. D., 1865, Report of progress and synopsis of the field work from 1860 to 1864, in Geology, v. 1: Geol. Survey Calif., 498 p.

Anonymous, 1943, Well drilling: War Dept. Tech. Manual TM 5-297. 


\section{INDEX}

A

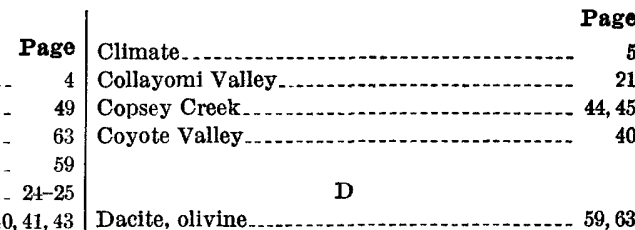

Agriculture

Alluvium, Bonfield Flat

Borax Lake Basin.

Burns Valley.

Coyote Valley...

Ely Flat.......................................

Excelsior Valley

Hesse Flat.

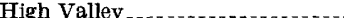

Little High Valley ...................... 45

Long Valley .............. 24-25

Long Valley (north) ................. 71-72

Lower Lake area. . . ....................... 52

Manning Flat........................... 49

older . . . 16-17

Recent. ............... 17-18

valley east of Clearlake Oaks............. 64

Anderson, C. A., quoted. ............... 15

Andesite .................................. 19

Artesian water, Burns Valley ............... 61

Coyote Valley ......................... 42-43

Lower Lake area. . . . . . . . . . . . . . 55-56

\section{B}

Backwashing

Basalt flows . . . . . . . .

Big Canyon Creek, capture of by Putah Creek ..................... 22-23

Bonfield Flat............ 49

Borax .................................... 63

Borax Lake _........ 57,63

Borax Lake Basin ........................... 62

Boron .................... 56-57, 62, 63, 65

Burns Valley ............................ 58

\section{C}

Cache Creek . . north fork of, runoff-

Cache formation, features of

Burns Valley .................. $58-62$

Lower Lake area . . . . . 52-56

Carpenter, E. J., and others, quoted......... 66

Casings..................................... 77

Chemical analyses of water, Collayomi

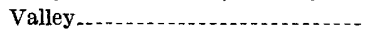

Coyote Valley

east of High Valley

Long Valley (north)

Lower Lake area. ............................ 56,57

Chico formation .............. 14, 20

Clear Lake

Clearlake Oaks, valley east of 63-64

Dacite, olivine

Deposition, periods of .......... 19-21

Drainage area, Bonfield Flat. .............. 49

Borax Lake Basin. . .......................... 62-63

Burns Valley ............................. 58

Collayomi Valley ....................... 21

Coyote Valley ............................. 40

Ely Flat.................................... 49

ExceIsior Valley ............................. 44

Hesse Flat. .................................. 49

High Valley............................. 65

Little High Valley............................ 44

Long Valley ............................... 21

Long Valley (north) .................... 71

Lower Lake area. ............................ 51

Manning Flat............................ 48

valley east of Clearlake Oaks . ......... 64

Drilling methods...... 77-79

E

Ely Flat....... 49

Erosion, periods of

Excelsior Valley

F

Franciscan group ................ 14, 18, 19

G

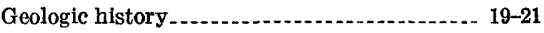

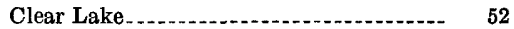

Collayomi Valley ............................. 22-23

High Valley.............................. 66

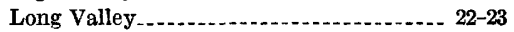

Ground-water development, Bonfield Flat.-.. 50,51

Borax Lake Basin......................... 63

Burns Valley ............. 58, 62

Collayomi Valley ..................... 21-22, 37-38

Coyote Valley ............................ 40,44

Ely Flat $\ldots \ldots \ldots, \ldots \ldots \ldots$

Exeelsior Valley ............................ 44, 48

Hesse Flat.................... 50,51

High Valley .......................... 65, 70-71

Little High. Valley .......................... 44,48

Long Valley......................... 21-22,37-38

Long Valley (north) .................... 71, 73-74

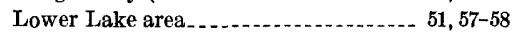

Manning Flat...................... 49

valley east of Clearlake Oaks ............ 6465 
Ground-water reservoirs

Page extent of development

safe yield

storage capacity, Bonfield Flat.

Burns Valley.

Collayoni Valley.........................

Coyote Valley.

Ely Flat................................

Excelsior Valley.

Hesse Flat.

Loug Valley

Long Valley (north)

Lower Lake area

\section{H}

Herndon Creek

Besse Flat.

High Valley

\section{I}

Indians

\section{$\mathbf{K}$}

Knoxville formation

Konocti, Mount

\section{L}

Lake Connty

Little High Valley

Logs of wells, Burns Valley

Collayouni Valley

Coyote Valley

Excelsior

Valley

Figh Valley .............................

information be be recorded

Long Valley

Long Valley (north)

Lower Lake area

valley east of Clearlake Oaks

Long Valley

Long Valley Creek

Long Valley (north) ............................

Lower Lake area.

\section{M}

Manning Flat

Martinez formation

O

Obsidian. $18,19,49-51,59,63$

Overpumping

\section{$\mathbf{P}$}

Precipitation 6-13

Putah Creek analysis of water

$4,21,40$ capture of Big Canyon Creek by 43 gravel channels of............. 24,41 runoff.
Q

Page

Quackenbush Mountain ...................... 58

Quality of water, Borax Lake Basin ......... 63

Burns Valley.

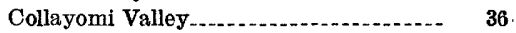

Coyote Valley.............................. 43.

High Valley ................................... 70

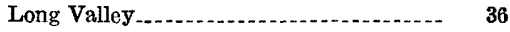

Long Valley (north) ...................... 72 .

Lower Lake area........................ 53, 56 .

valley east of Clearlake Oaks............. 65

\section{$\mathbf{R}$}

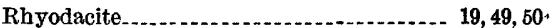

Round Mountain ............................ 66 .

Runoff, Long Valley Creek

Putah Creek ..................................

\section{S}

Schind ler Creek $64,65,66,69$. Seigler Canyon Creek

Serpentine....................................... 18 .

Shasta series ................................. 14, 20 .

Springs

Excelsior Valley .......................... 44

High Valley ................................ 70

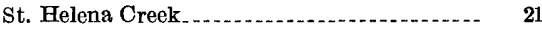

gravel channels of ..................... 24

Surging ............ 79

$\mathrm{T}$

Terraces, Burns Valley ..................... 58

Collayomi Valley ........... 23-24

Tehama formation....................... 16

Tejon formation.

Temperatures ................................ 5

Thurston Creek........................ 49,

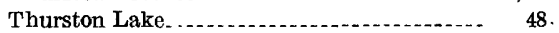

\section{V}

Vegetation

Volcanic rocks, features of ............... 18-19, 20.

W

Water levels, geueral discussion of........ $\quad 76$.

Bonfleld Flat.......................... 51

Burns Valley................................ 60-61

Collayomi Valley ................ 26-27

Coyote Valley ................. 42.

Ely Flat.................................... 51

Excelsior Valley . .

Hesse Flat.........................................

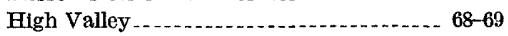

Long Valley ... ............

Long Valley (north)

Lower Lake area. ... . . . . . . . . . . . . 54-55. 
Page | Wells, etc-Continued $\quad$ Page

Wells, descriptions, Borax Lake.

33-34

Bonfield Flat

Hesse Flat...

32

Burns Valley

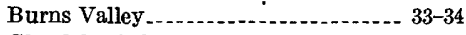

Clearlake Oaks area.

High Valley

Long Valley ...................... 280

Long Valley (north)

Lower Lake area. . . . . . . . . .

Coyote Valley ......................... 30-31

Ely Flat............. 32

Excelsior Valley...................... 31-32

Manning Flat......................... 32

methods of development................. 79

numbering system...................... 3 